University of Nebraska - Lincoln

DigitalCommons@University of Nebraska - Lincoln

Papers in the Earth and Atmospheric Sciences

Earth and Atmospheric Sciences, Department

$12-2020$

\title{
Estimating the Age and Mechanism of Boulder Transport Related with Extreme Waves Using Lichenometry
}

\author{
Maria A. Oliveira \\ Universidade de Lisboa, Portugal, maoliveira@fc.ul.pt \\ Esteve Llop \\ Universitat de Barcelona, ellop@ub.edu \\ César Andrade \\ Universidade de Lisboa, Portugal, candrade@ciencias.ulisboa.pt \\ Cristina Branquinho \\ Universidade de Lisboa, Portugal \\ Ronald Goble \\ University of Nebraska-Lincoln, rgoble2@unl.edu
}

See next page for additional authors

Follow this and additional works at: https://digitalcommons.unl.edu/geosciencefacpub

Part of the Earth Sciences Commons

Oliveira, Maria A.; Llop, Esteve; Andrade, César; Branquinho, Cristina; Goble, Ronald; Queiroz, Sónia;

Freitas, Maria C.; and Pinho, Pedro, "Estimating the Age and Mechanism of Boulder Transport Related with Extreme Waves Using Lichenometry" (2020). Papers in the Earth and Atmospheric Sciences. 644.

https://digitalcommons.unl.edu/geosciencefacpub/644

This Article is brought to you for free and open access by the Earth and Atmospheric Sciences, Department of at DigitalCommons@University of Nebraska - Lincoln. It has been accepted for inclusion in Papers in the Earth and Atmospheric Sciences by an authorized administrator of DigitalCommons@University of Nebraska - Lincoln. 


\section{Authors}

Maria A. Oliveira, Esteve Llop, César Andrade, Cristina Branquinho, Ronald Goble, Sónia Queiroz, Maria C. Freitas, and Pedro Pinho 
Published in Progress in Physical Geography: Earth and Environment 44:6 (December 2020), pp. 870889; doi: 10.1177/0309133320927629

Copyright (C) 2020 Maria A Oliveira, Esteve Llop, César Andrade, Cristina Branquinho, Ronald Goble, Sónia Queiroz, Maria C Freitas, and Pedro Pinho. Published by SAGE. Used by permission. Published online June 17, 2020.

Supplemental material follows the references.

\title{
Estimating the Age and Mechanism of Boulder Transport Related with Extreme Waves Using Lichenometry
}

\author{
Maria A Oliveira, ${ }^{1}$ Esteve Llop, ${ }^{2}$ César Andrade,${ }^{3}$ Cristina Branquinho, ${ }^{4}$ \\ Ronald Goble, ${ }^{5}$ Sónia Queiroz, ${ }^{6}$ Maria C Freitas, ${ }^{7}$ and Pedro Pinho ${ }^{4}$
}

1. cE3c e IDL, Faculdade de Ciõncias, Universidade de Lisboa, Portugal, and College on Polar and Extreme Environments (Polar2E), University of Lisbon, Portugal

2. Department of Evolutive Biology, Ecology, and Environmental Sciences - Botany and Mycology, Universitat de Barcelona, Faculty of Biology, Spain

3. Instituto Dom Luiz, Faculdade de Ciências da Universidade de Lisboa, Portugal Departamento de Geologia, Faculdade de Ciências da Universidade de Lisboa, Portugal

4. Centre for Ecology, Evolution, and Environmental Changes, Faculdade de Ciõncias da Universidade de Lisboa, Portugal

5. Department of Earth and Atmospheric Sciences, University of Nebraska-Lincoln, Lincoln, Nebraska, USA

6. Instituto Dom Luiz, Faculdade de Ciências da Universidade de Lisboa, Portugal

7. Instituto Dom Luiz, Faculdade de Ciõncias da Universidade de Lisboa, Portugal Departamento de Geologia, Faculdade de Ciências da Universidade de Lisboa, Portugal

Corresponding author - Maria A Oliveira, Centre for Ecology, Evolution, and Environmental Changes, Faculdade de Ciências da Universidade de Lisboa, Edifício C2, $6^{\circ}$ Piso, Sala 2.6.13, Campo Grande, 1749-016 Lisboa, Portugal, email maoliveira@fc.ul.pt 


\begin{abstract}
Tsunamis and storms cause considerable coastal flooding, numerous fatalities, destruction of structures, and erosion. The characterization of energy and frequency associated with each wave contribute to the risk assessment in coastal regions. Coastal boulder deposits represent a physical proof of extreme inundation and allow us to study the effects of marine floods further back in time than instrumental and historical records. Age estimation of these deposits is challenging due to lack of materials (such as sand, shells, corals, or organic matter) that retain information about the passage of time. Lichenometry, a simple age estimation method, which is cost effective, quick to apply, and nondestructive, is here proposed as a solution. A lichen growth model for a calcium-tolerant lichen species was developed and used to estimate the age of a boulder deposit related to extreme marine inundation(s) in Portugal. Estimated ages indicate several very recent events ( $<700$ years) for most of the boulders' stabilization and agree with results obtained with optically stimulated luminescence of marine sands found beneath boulders. Frequent and recent boulder transport implies a stormorigin for this deposit. These conclusions contrast with other works describing identical deposits that are attributed to paleo-tsunamis. This study presents a methodology using lichenometry as a successful alternative for age estimation in rocky coastal settings. These results offer an alternative explanation for coastal boulder deposits found on the west coast of Portugal.
\end{abstract}

Keywords: rocky coastline, limestone, frequency, optically stimulated luminescence, Portugal

\title{
I. Introduction
}

Age estimation of sediments is crucial in geosciences in cases allowing validation or rejection of conceptual models. In this context, age estimation is a powerful tool for reconstructing the chronology and return period of extreme marine inundations, which is relevant for coastal hazards and risk assessment (Marriner et al., 2017). In what concerns coastal boulder deposits, this is a challenging task due to a lack of materials that retain information about the passage of time since deposition, such as sand, shells, corals, and organic matter. The distinction between storm and tsunami events in boulder accumulations is no trivial task and is a highly debated issue (Cox et al., 2018; Marriner et al., 2017; Vött et al., 2019). This distinction is especially relevant when addressing coastal areas with a high risk of tsunami inundation, such as Portugal (cf. Muir-Wood and Mignan, 2009), as both events are characterized by different return periods (decades for extreme storms and centuries to millennia for tsunamis).

The chronology of onshore boulder movement by waves can be obtained with radiocarbon ages of biogenic calcium carbonate attached to or beneath boulders (Costa et al., 2011; Hall et al., 2006; Jones and Hunter, 1992; Mastronuzzi et al., 2007; Nott, 1997, 2000; Rixhon et al., 2018; Scheffers et al., 2009; Schneider et al., 2019; Suzuki et al., 2008) by electron spin resonance dating of coral boulders (Scheffers et al., 2014), and by uranium-series radiometric age dating (Remy et al., 2018; Scheffers et al., 2014; Terry et al., 2016). Moreover, optically stimulated luminesce (OSL) dating of sand has been used to constrict the age of boulder deposition (Hall et al., 2006; Kennedy et al., 2007). Another possibility is cosmogenic nuclide build-up applied to rock samples taken from exposed horizontal surfaces. However, this method has limitations in what concerns rock thickness $(>0.5 \mathrm{~m}$ for limestone rocks) and increased uncertainties in rocky coastline contexts and boulder 
deposits (cf. Darvill, 2013; Hurst et al., 2017; Masarik and Wieler, 2003; Trenhaile, 2018). Regardless, cosmogenic ${ }^{3} \mathrm{He}$ or ${ }^{36} \mathrm{Cl}$ age estimation was successfully applied to large boulders attributed to extreme marine events (Ramalho et al., 2015; Rixhon et al., 2018). When materials suitable for age estimation are not available, alternative methods must be considered. In this context, lichenometry stands out as a possible dating methodology of rock surface exposure (including boulder surfaces).

Lichens are a symbiosis between an algae or cyanobacteria and fungi that maintain their morphology and grow very slowly. This feature has allowed their use in lichenometry, which rests on the relationship between lichen size and age (Beschel, 1961; McCarthy, 1999). If the growth of a lichen species is known, the time elapsed since exposure and stabilization of a rock surface can be inferred from the size of the lichens. Lichens with concentric growth have been widely used since the 1960s to estimate the age of recent glacial and periglacial deposits (e.g., Birkeland, 1982; Carrara and Andrews, 1975; Garibotti and Villalba, 2017; Hansen, 2008; O'Neal and Schoenenberger, 2003; Orwin et al., 2008; Pendleton et al., 2017; Proctor, 1983; Roberts et al., 2010; Roof and Werner, 2011; Rosenwinkel et al., 2015; Trenbirth and Matthews, 2010). Furthermore, lichenometry was applied to rockfall debris (Bull, 2014; McCarrol et al., 2001), debris-flow deposits (Innes, 1983; Jonasson et al., 1991), cobble and boulder beaches in coastal regions (Broadbent and Bergqvist, 1986), and fluvial deposits (Fouldsetal., 2014; Gobetal., 2003).

Absolute age estimation using lichenometry requires control points (i.e., substrates with a known age of exposure) and a function correlating the size of lichens with time, referred to as a growth curve (Armstrong, 2004; Innes, 1985). This curve must be built for a given lichen species (or genus) and environmental conditions in which the deposits or surfaces to be dated occur. In the absence of control points, a growth-rate curve can also be built by monitoring the growth of lichen thalli of different sizes, and by assuming a direct relationship between lichen size and age (Armstrong, 2015). Lichenometry is mostly useful for dating the past 500 years, its upper limit of applicability being determined by senescence and competition among individuals (Armstrong, 2004; Beschel, 1961; Innes, 1985; Noller and Locke, 2000).

Lichenometry has been contested by several authors due to methodological issues and sources of errors (Decaulne, 2016; Jochimsen, 1973; Jomelli et al., 2007; McCarthy, 1999; Osborn et al., 2015; Worsley, 1990). Arguments against the technique include the unknown influence of ecological variables in lichen growth; factors related to population dynamics, such as lichen competition, mortality, and rapid population turnover; inheritance of older lichens from previously exposed rocks; sampling techniques, including between-operator variance, the use of lichen diameter in elongated thalli, and the number of thalli sampled; lichen identification in the field; and the lack of uncertainty or statistical validity.

Some of the drawbacks of this technique can be overcome by sampling in microhabitats showing optimal lichen growth (Decaulne, 2016; McCarthy, 1999; Trenbirth and Matthews, 2010). Decadal and century-scale climate change affecting lichen growth rates can be incorporated by using indirectly established lichen growth curves (Armstrong, 2015; Innes, 1985). Changes in growth rates due to competition can be avoided by using only isolated thalli. Highly dynamic populations are not a problem if life-cycle processes are similar in sampled surfaces (Armstrong, 2016), which can be checked by monitoring lichen growth 
and mortality (Decaulne, 2016). Inheritance can be detected with systematic sampling coupled with statistical analysis based on the variance of lichen size (Rosenwinkel et al., 2015). Between-operator variance can be resolved with all measurements being taken by the same person (Innes, 1985). Irregular thalli can be measured as the surface area based on photographic records (Roof and Werner, 2011; Worsley, 1990). Issues related to the limited number of individuals measured by using the largest thallus or the five largest thalli colonizing a surface can be resolved by using a size-frequency approach (Bradwell, 2004). The correct identification of lichen species is an inevitable necessity to minimize sources of error, and it can be resolved by collaborating with taxonomists (Decaulne, 2016). Finally, by using available statistical software (such as R), statistical uncertainty can be included in predictions.

Regardless of all the uncontrolled factors, the large number of successful and reproducible results indicates that lichen size is a reasonable measure of the age of a geological deposit (Innes, 1985). Although rare, studies of lichen growth in calcareous substrates exist (Maas and Macklin, 2002; Trudgill et al., 1979). However, applications to rocky substrates exposed to the harsh coastal environment are few and comprise the use of this technique as a relative age estimator (cf. Williams and Hall, 2004).

In this work, we show an innovative approach to the chronology of coastal boulder emplacement by extreme marine events in rocky limestone coastal contexts, by using lichenometry, combined with OSL. A calibration curve, including uncertainty, was developed using lichens in control points with known age, including manmade masonry structures in coastal forts and rock-scars from slope mass movements. The growth curve was used to constrain the age of emplacement of limestone boulders in a coastal deposit. The lichen species Opegrapha durieui Mont. (Roux and Egea, 1992) was used for this purpose. By estimating the age of boulder deposition, we aim to clarify the origin (tsunami versus storm) of the boulder accumulation in a region with a high risk of tsunami inundation. The approach presented herein can be applied to other coastal contexts elsewhere, provided that local control points are used for model calibration, and that sampling strategies take into consideration lichen species ecology.

\section{Study area}

\subsection{Boulder deposit}

The boulder deposit is located on the west coast of Portugal, approximately $40 \mathrm{~km} \mathrm{NW}$ of Lisbon (Figure 1(a)). Tides are semidiurnal, and considering one Saros cycle, the highest astronomical spring tide reaches $1.8 \mathrm{~m}$ amsl (above mean sea level); the mean spring tidal range is $2.8 \mathrm{~m}$ (Instituto Hidrográfico, 1985-2003). Layers outcropping in the study area comprise uplifted marine transgressive-regressive sequences deposited during the lower Cretaceous (Rey, 2007). The sequence is slightly dipping to SW $\left(6-10^{\circ}\right)$ and formed by alternating crystalline limestone to sandy limestone layers at the base (Units A-D), followed by claystone, sandstone, and marl (Unit E) (Figures 1(b) and (c)). The basal sequence (Units B-D) forms wide ramps, benches with protruding limestone layers, and low vertical cliffs $(<20 \mathrm{~m})$. These evolve by rock-fall due to breakdown along bench and cliff edges, forming boulders with varying sizes reflecting bed thickness and joint spacing. Wide structural 
platforms develop between each unit, forming benches up to $3 \mathrm{~m}$ high. Marl, sandstone, and mudstone layers outcropping at the top of the sequence (Unit E) form low-sloping cliffs that evolve by gullying and mass movement, generating colluvium. Limestone layers from Units $C$ and $D$ differ from each other in their composition (ranging from crystalline to sandy limestone), in fossil content, surface morphology, thickness, and joint frequency and direction (Oliveira, 2017).
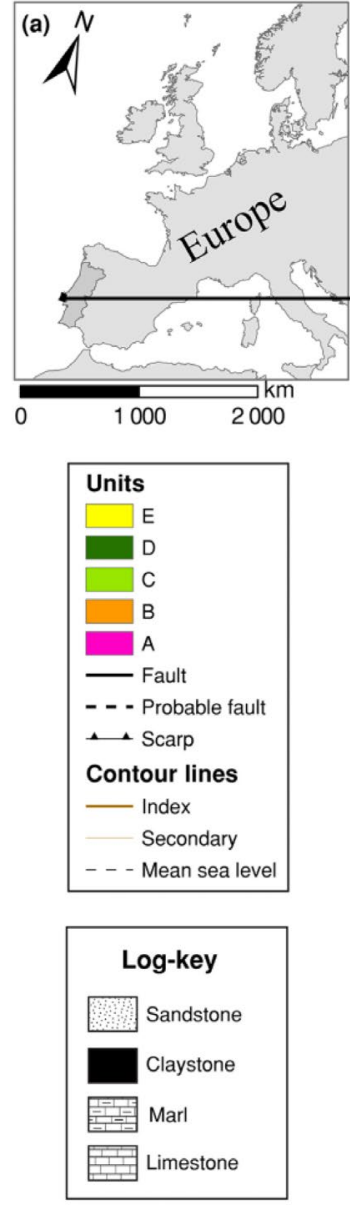
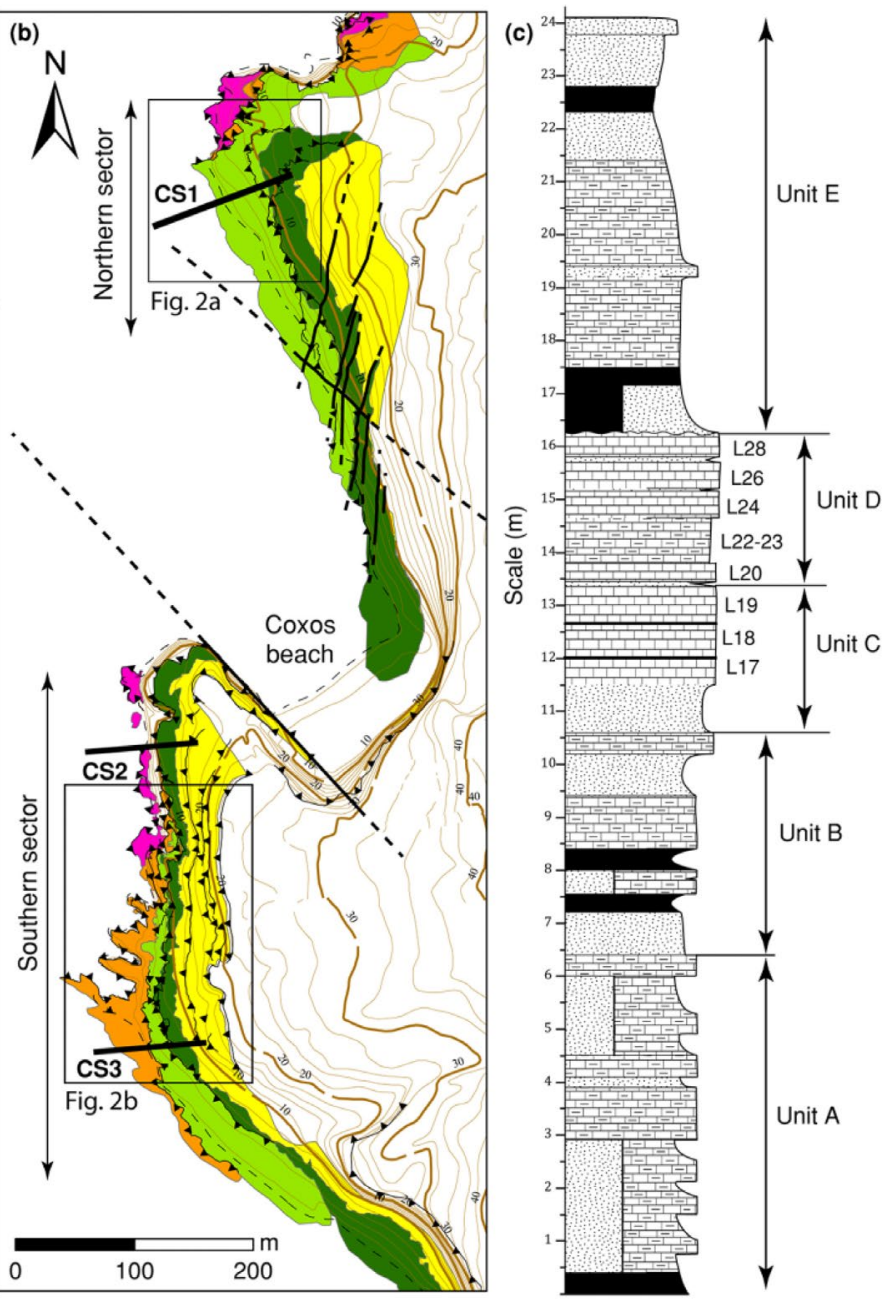

Figure 1. (a) Location of the study area in Europe and Portugal. (b) Geological units (A-E), location of cross-sections (CS1-3) represented in Figure S1 in the supplemental material, and insets represented in Figures 2(a) and b. (c) Schematic log of the units.

The deposit comprises 1500 supratidal limestone boulders up to 30 tons at $2-13 \mathrm{~m}$ amsl, both north and south of Coxos beach, on top of the structural surfaces formed by Units $C$ and D (Figures 2(a) and (b)). Only boulders showing evidence of transport against gravity were addressed in this study. Boulders sitting on top of Unit $C$ were sourced in layers 17-19, 
and boulders sitting on top of Unit D were sourced in layers 20-28 (Figure 1(c)). Transported particles originated in overhanging or notched limestone layers exposed to storm wave swash, some of them having been overturned and broken during transport. Boulders show a landward and northward size-grading trend, decreasing in size as the elevation increases, in agreement with the general slope of the structural surface (Figures 2(a) and (b), and Figure S2 in the supplemental material). Larger boulders ( $>10$ ton) are generally located inland of natural indentations in the lower structural platform, and either lean against bench edges or sit horizontally and isolated, close to the edge of the benches (Figures 2(a) and (b), and Figure S3(a) in the supplemental material). Further inland, closer to the inner edge of the structural platforms, boulders are smaller $(<2.5$ ton). They are organized in ridges and clusters of imbricated boulders (Figures 2(a) and (b), and Figure S3(b) in the supplemental material). In the southern sector, the development of colluvium deposits partially buries some of the boulders (Figure S3(c) in the supplemental material). Isolated boulders found near the edge of the cliffs/benches are sometimes close to sockets matching their size, interpreted as their original location. 


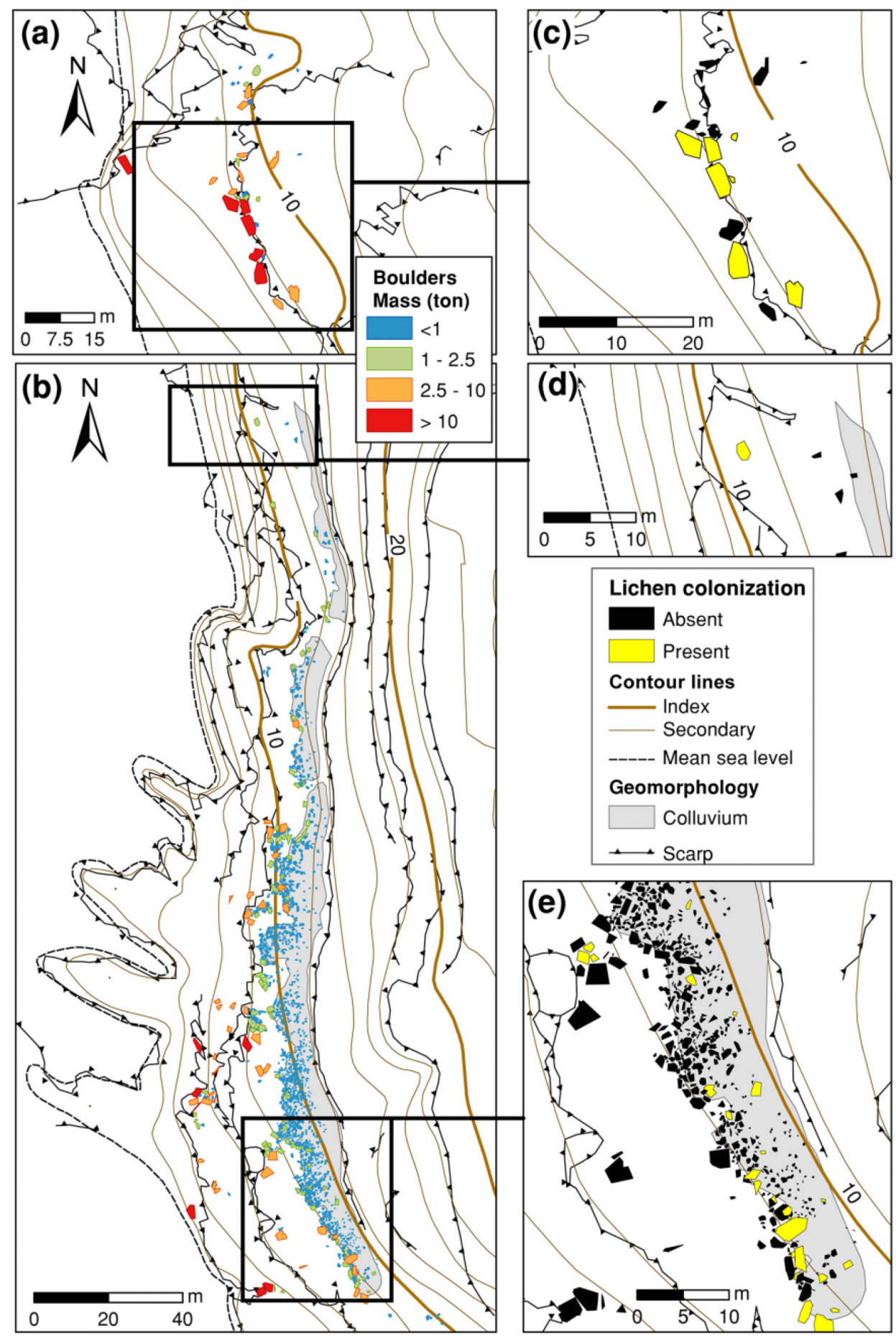

Figure 2. (a), (b) Boulder mass north and south of Coxos beach. (c), (d), (e) Boulders colonized by the lichen species Opegrapha durieui. 
The lichen species $O$. durieui colonized 32 boulders forming ridges and imbricated clusters, and an isolated boulder on top of a cliff at $12 \mathrm{~m}$ amsl (Figures 2(c)-(e), and Figure S3(d) in the supplemental material). Boulders colonized by lichens within clusters were surrounded by many other large clasts but lacked colonization by this lichen species.

Boulder movement up to $12 \mathrm{~m}$ amsl was observed in the study area in January and February of 2014 (Oliveira et al., 2020). However, the inner part of the ridges with boulders colonized by lichens remained generally untouched. A patch of marine sand was found beneath boulders within a ridge, at $9 \mathrm{~m}$ amsl (Figure 3). Before the storms, this material was covered by boulders and colluvium. The marine sand patch comprised a poorly sorted fine sand with a bimodal distribution, containing sub-rounded, coated, clean, and polished quartz grains, lithoclast, and bioclasts (Oliveira, 2017). Grain size, morphology, composition, and morphoscopic surface features of the quartz grains contrast with material from the beach, the colluvium deposit, and sand collected in the lower rocky platform after storms (cf. Oliveira, 2017) (data shown in Table S1 and Figures S4 and S5 in the supplemental material).

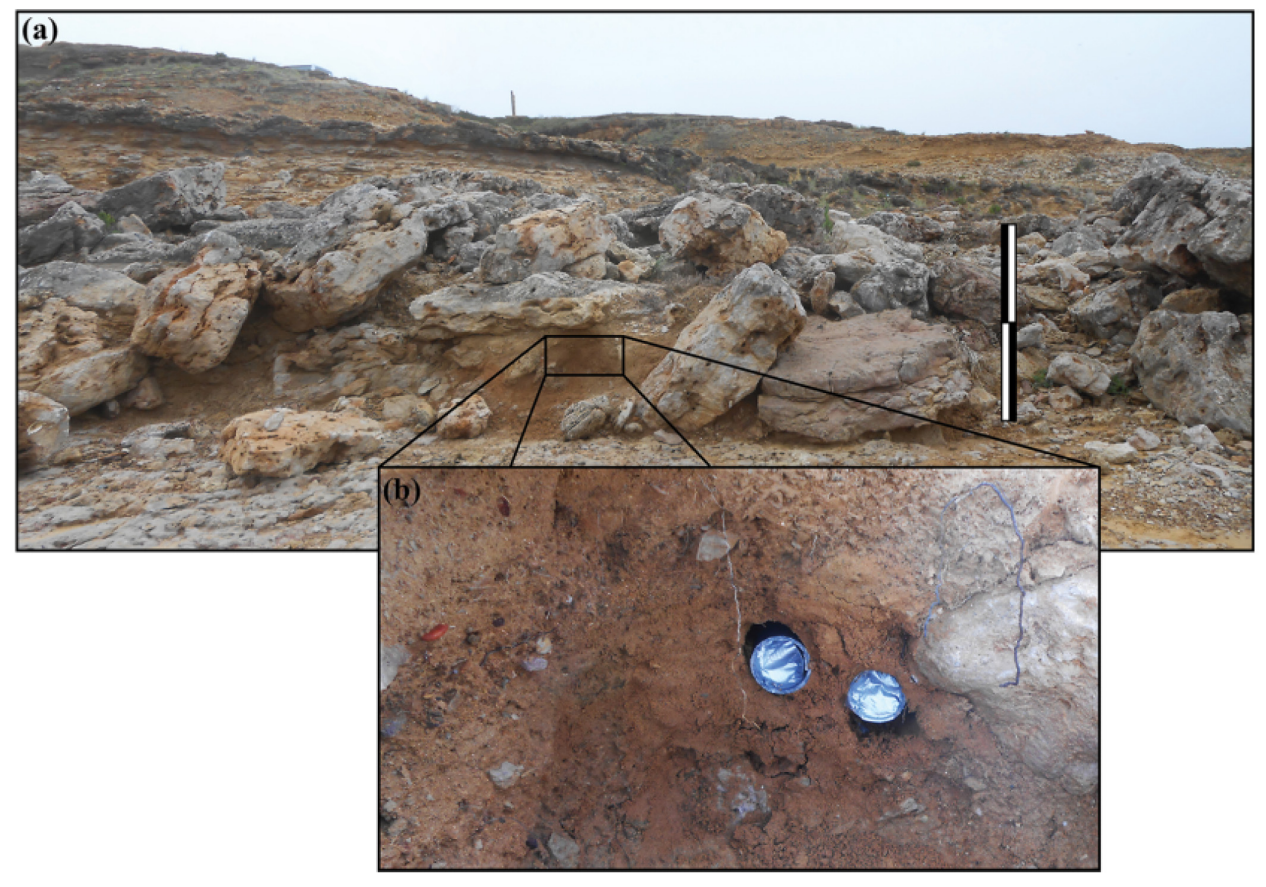

Figure 3. (a) Front view of the boulder ridge and exposed sand patch beneath the boulders (1 m scale). (b) Sampling for optically stimulated luminesce age estimation.

\subsection{Lichen species on boulders at Coxos deposit}

O. durieui is a slow-growing and circular species, and therefore an excellent candidate to be used in geochronology (Innes, 1985; Noller and Locke, 2000). Lichen species with Trentepohlia as the photobiont, such as O. durieui, are more abundant in humid and warm conditions and common in tropical and subtropical regions (Nimis and Tretiach, 1995; Sipman 
and Harris, 1989). There is a positive relationship between Trentepohlia lichen richness and temperature (Aptroot and van Herk, 2007; Marini et al., 2011; van Herk et al., 2002). Moreover, lichens with Trentepohlia are more frost susceptible than species containing other photobionts, such as Trebouxia or Nostoc (Nash et al., 1987). The development of lichens with Trentepohlia is linked to high levels of moisture and precipitation, being more abundant in rainy and oceanic areas (Marini et al., 2011; Rindi and Guiry, 2002).

O. durieui colonizes calcareous rocks in the supra-littoral fringe subject to sea spray, in the Mediterranean and adjacent Atlantic coasts of Morocco and Portugal, where humidwarm climates dominate (Nimis, 2016; Roux and Egea, 1992; Sipman and Raus, 1999). Lichen thalli are generally found in very steep to vertical and overhanging humid cliff faces looking north (Nimis, 2016) and are absent in near-horizontal dry surfaces with high exposure to sunlight (Roux and Egea, 1992). The ecology of the lichen species O. durieui is particular, narrowing its distribution to a thin strip in the coastal area $(<50-75 \mathrm{~m}$ inland from the sea). On the one hand, this species does not tolerate frequent and direct seawater and is not found close to the direct effect of sea spray, this niche being occupied by other lichen species. On the other hand, it is rarely found away from the coastline. These taxa are bound to maritime-coastal situations (Nimis, 2016). The restricted ecology of this lichen species assures that sites where it is found share similar ecological/climatic conditions.

O. durieui forms white, thin, continuous to cracked and areolate epilithic thalli, with a white prothallus. Apothecia are lirellated, almost immersed in the thallus, black with a whitish pruina, simple to irregularly branch and 1-2 mm long (Figure 4). When two thalli coalesce, one of two things occurs: the more competitive thallus overgrows the weakest, which eventually dies, or they form a contact boundary and keep colonizing the surrounding areas. These boundaries form perceptible, thick, linear, and segmented features (Figure 4). 


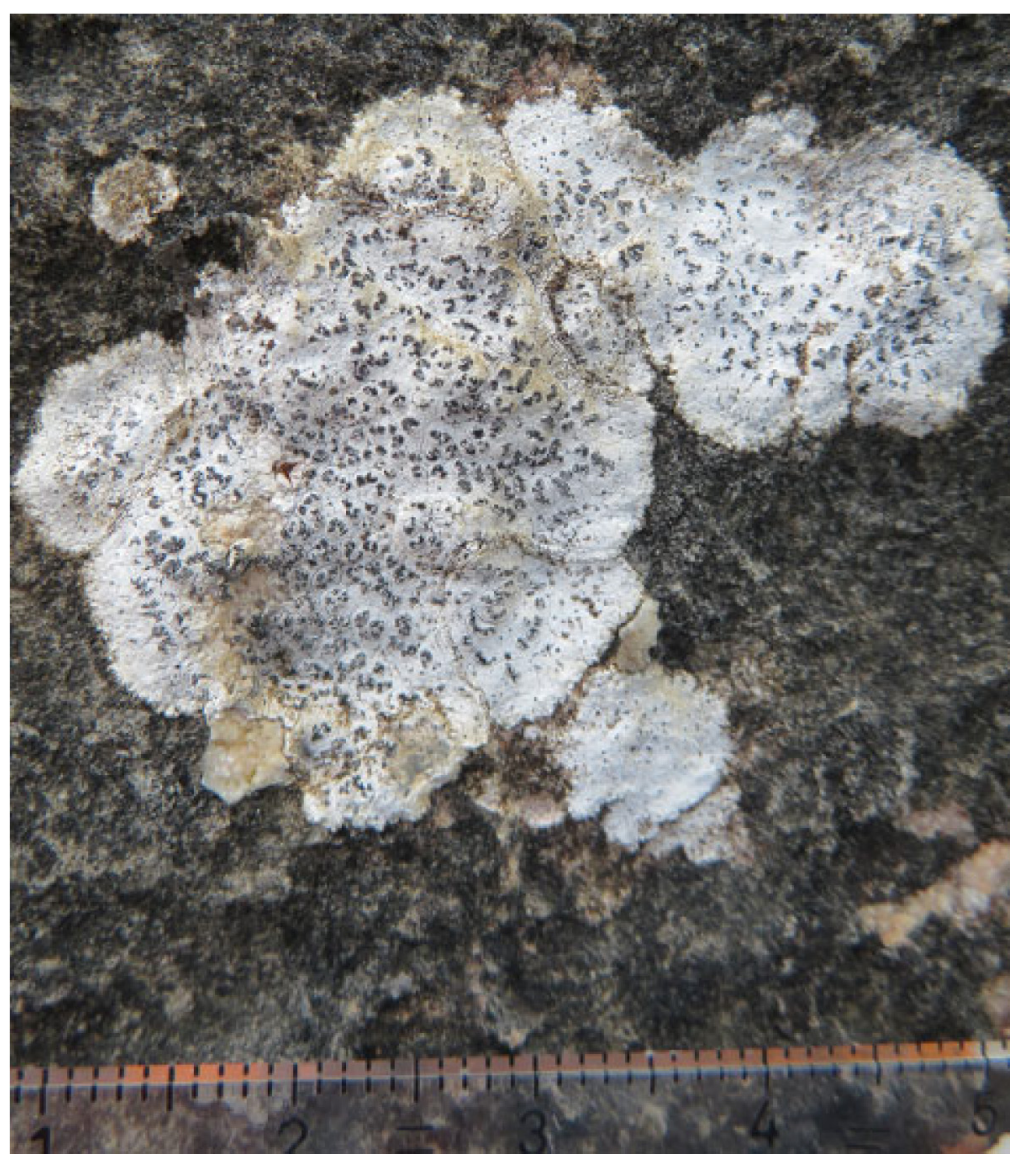

Figure 4. Coalescing thalli of Opegrapha durieui.

\section{Methods}

\subsection{Selection of control points}

The calibration curve was based on data from 14 control points located along the Portuguese coast (detailed description in the supplemental material) (Figure 5). Surfaces include shelly, clastic to crystalline limestone, and concrete. Although these materials show different physical, mineralogical, textural, and chemical characteristics, they all contain calcium carbonate in high proportions, which controls the $\mathrm{pH}$ of the substrate. Control points include selected manmade masonry structures found in coastal forts and other artificial structures and recent (<70 years) scars from slope mass movements. 


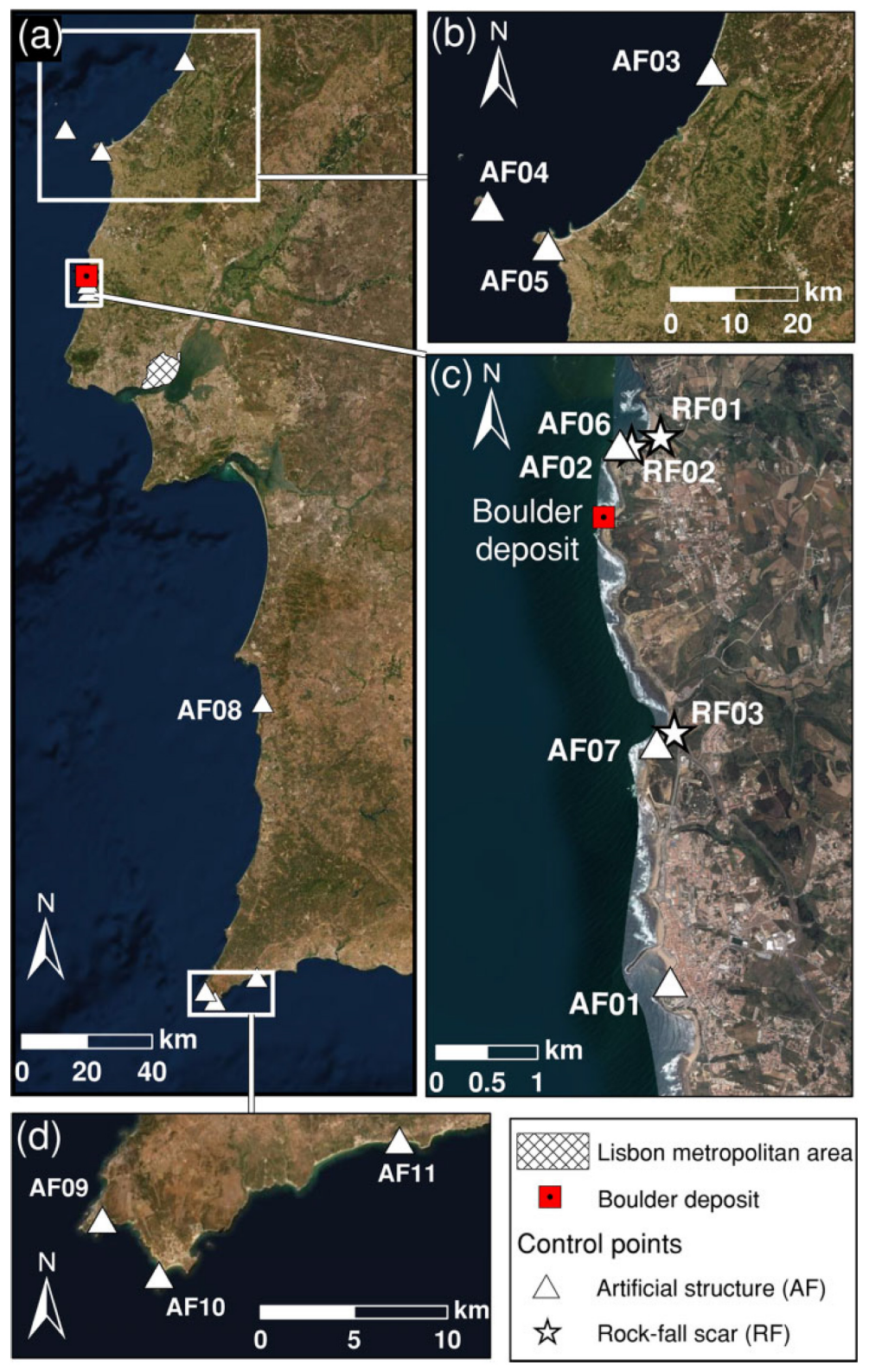

Figure 5. Location of the boulder deposit and control points along the coastline (maps built with Esri ArcMap 10.5.1.7333; source of satellite images: Esri, DigitalGlobe, GeoEye, Earthstar Geographics, CNES/Airbus DS, USDA, USGS, AeroGRID, IGN, and the GIS User Community).

\subsection{Identification of lichen species}

Identification of voucher samples of lichens was based on macroscopical and microscopical characters, and chemical features, following Clauzade and Roux (2002) and Smith et al. (2009). In the field, lichen species was identified by scratching the areola and finding the 
color orange due to the presence of carotenoids in the Trentepohlia photobiont (Friedl and Büdel, 2008).

\subsection{Indirect measurements: Lichen size and cover}

Three lichen age variables were tested: the average diameter of the largest inscribed circle observed in the five largest thalli, as suggested by Innes (1985), hereafter named $\varnothing$ (Figures $6(\mathrm{a})$ and (b)); the area of the circle represented by $\varnothing$, herein represented as $A$, and obtained from the mathematical expression relating the diameter and the area of a circle: $A=\pi(\varnothing / 2)^{2}$; and lichen cover percentage over standard control areas (Figures 6(c) and (d)). Control surfaces are steep $\left(72^{\circ}\right.$ to vertical), face north, and are near the coastline $(<150 \mathrm{~m})$. The selection of the largest thalli was based on visual inspection, and their measurement was performed to the closest millimeter using a ruler. Measurements were made by the same operator to minimize errors associated with between-operator variance (cf. Innes, 1985). Irregularities in growth rates due to coalescence were avoided by sampling isolated thalli with clear margins and circular growth. Cover measurements were performed in areas presenting the highest lichen cover. The sampling location was registered using a RealTime Kinematic Global Positioning System, and the azimuth and slope of each surface was obtained with a compass and clinometer.
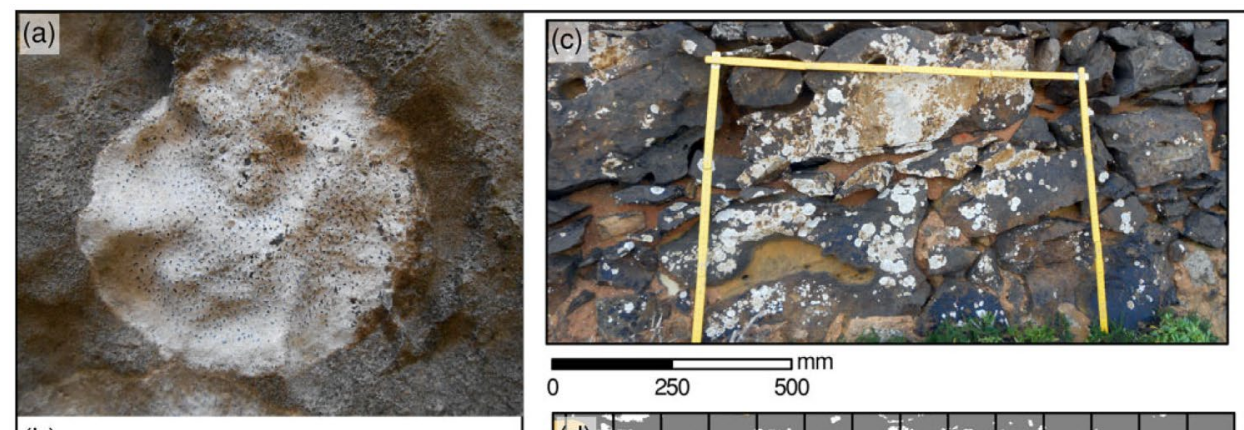

(b)
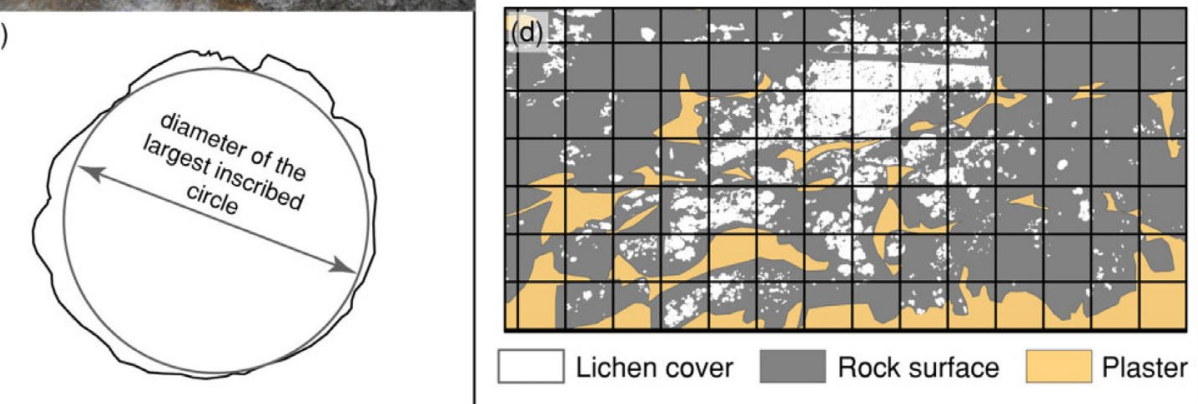

Figure 6. (a) Opegrapha durieui thallus. (b) Same extent as (a) showing the diameter of the largest inscribed circle. (c) Mosaic of a surface colonized by O. durieui. (d) Same extent as (c) after image processing and overlapping a $10 \mathrm{~mm} \times 10 \mathrm{~mm}$ grid.

Age determination of manmade control surfaces AF02-AF08, AF10, and AF11 were based on the compilation of historical information of Portuguese monuments by Almeida 
(1946), Costa (1997), Coutinho (1997), Machado (2009), Mateus (1999), Mesquita (2000), Quaresma (2007), Severino (2014), and Silva (2013), and by official government-issued bulletins describing the general state and reconstruction of national monuments (Direção Geral dos Edifícios e Monumentos Nacionais, 1953, 1960). For the manmade control surface AF01 and the rock-scar RF03, age determination was based on the comparison of aerial photographs from 1980, 1989, and 2000. For the rock-scars RF01 and RF02, age determination was based on field surveys and further constricted by public photographic records of the area and by eye-witness accounts. In many control points, it was only possible to attribute an age range, rather than a number. In these cases, a middle date was assumed. Further details on age determination for all control surfaces are available in the supplemental material.

Growth rates were determined by dividing the lichen age variable (diameter, area, or lichen cover) with the age of the control surfaces. Local climatic variables (temperature, water vapor pressure, solar radiation, and precipitation) with a resolution of $\sim 1 \mathrm{~km}$, averaged for the years 1970-2000, were extracted for each control point from the WorldClim Version2 climate dataset (Fick and Hijmans, 2017). Altitude, distance from the coastline, and average climatic variables were compared with growth rates to assess the influence of environmental variables on lichen growth. Although climatic changes associated with local factors cannot be assessed using a 1-km grid, it allowed us to assess climatic changes between control points with different coastline exposure (N- versus S-facing coastline) and along the $\mathrm{W}$ coast of Portugal.

The same lichen size sampling methodology was used in the control points and boulder deposit. O. durieui was always found colonizing shaded surfaces, such as $\mathrm{N}$-facing boulder faces, faces shadowed by larger boulders, or undersides of tilted boulders. In four boulders, smaller living lichen thalli were found persistently covering larger dead lichen thalli. In these cases, both larger and smaller populations presented consistent sizes between them, indicating the generalized death of the largest population. Given that lichens grew on the same boulder surface, lichen death must have been caused by changes in environmental conditions (e.g., boulder burial by finer sediments that washed out from sedimentary layers outcropping above, or temporary changes in temperature/moisture) and not by boulder movement. Once optimal ecological conditions resumed, so did lichen regrowth, here represented by the smaller population. In these cases, age will be underestimated and can be attributed only to the event that killed the largest population. In the northern sector, cliffs located seaward of the boulder deposit were found colonized by the lichen species. In this sector, and to avoid inheritance, only lichens colonizing undersides of overturned boulders (surface initially facing upward) were considered.

Quantification of lichen cover was based on photographs following the method of McCarthy and Zaniewski (2001). A folding ruler was placed in front of the rock surface for scaling. Photographs were taken with the camera parallel to the rock surface. Selected surfaces were photographed at close range in small and partly overlapping sections to maintain the best resolution for mosaic construction. Mosaics were built using photo stitching software (Adobe Photoshop or Hugin version 2013.0.0.0d404a 7088e6) and scaled in geographical information system (GIS) software (Esri ArcMap). The lichen cover area was extracted using photo editing software (Adobe Photoshop). Scaled mosaics containing the 
extracted areas were classified and converted into polygons using automatic image classification tools from the GIS software (Figure 6(c)). Areas clear of lichen colonization were quantified and used to determine the percentage of lichen cover. The polygons representing colonized surfaces were split into $100 \mathrm{~mm} \times 100 \mathrm{~mm}$ grid cells (Figure $6(\mathrm{~d})$ ). The grid cell showing the highest value of lichen cover was selected as an initial control surface (minimum area considered). The surrounding grid cells were then successively summed in $100 \mathrm{~mm}$ increments $(200 \mathrm{~mm} \times 200 \mathrm{~mm}, 300 \mathrm{~mm} \times 300 \mathrm{~mm}$, and so on), and the total area covered by lichens was determined for each increment. Area covered, percentage, and standard deviation were plotted for each control point to determine the area better representing lichen age.

\subsection{Lichen growth model}

Assumptions of linear regression (normality of error distribution and homoscedasticity) were verified in the dataset comprising percentage of lichen cover, $\varnothing, A$, and age of control surfaces. The error distribution was tested for normality using a Shapiro-Wilk normality test, and the data were tested for homoscedasticity using a $t$-score test for nonconstant error variance (Fox and Weisberg, 2011), with the shapiro.test and ncvTest functions (stats and car packages) in R software (R Core Team, 2017). In both tests, the $p$-values obtained were higher than 0.05 , indicating that residuals were normally distributed and that the variance was constant. The growth model was based on the best fit to lichen age variables versus time using the $\mathrm{lm}$ function (stats package) in the $\mathrm{R}$ software. Moreover, age estimations were obtained with the function relating lichen size and age. Prediction intervals, which provide an estimate of individual observations, were determined using the predict function (stats package) also in the R software, based on the following set of equations (Freund et al., 2006; Moore et al., 2009):

$$
\begin{gathered}
\text { prediction intervals }=\hat{\mu}_{y \mid x} \pm t^{*} S E_{\text {estimate }} \\
S E_{\text {estimate }}=\sqrt{M S E\left(1+\frac{1}{n}+\frac{\left(x^{*}-\bar{x}\right)^{2}}{S_{x x}}\right)} \\
M S E=\frac{\sum\left(y-\hat{\mu}_{y \mid x}\right)^{2}}{n-2} \\
S_{x x}=\Sigma(x-\bar{x})^{2}
\end{gathered}
$$

Predicted values are denoted by $\hat{\mu}_{y \mid x}$ and $t^{*}$ represents the critical point of the $t$ distribution for the desired significant level with $(n-2)$ degrees of freedom, $n$ being the number of observations. Observed values of the dependent variable are represented by $y, x^{*}$ represents the specific value of $x$ for which the intervals are determined, and $\bar{x}$ the mean of observed values of the independent variable. Prediction intervals were determined considering a 0.95 confidence interval (2-sigma), for which $t(12)$ equals 2.179. 


\subsection{Direct measurements of lichen growth}

Direct measurements were based on the comparison of photographic records taken on different dates, inspired by the methodology described by Brabyn et al. (2005) and Roof and Werner (2010). Photographs taken between 2013 and 2016 showed enough quality to differentiate and outline thalli and, in some cases, to detect lichen coalescence. Surfaces included manmade and rock-scar control surfaces north of the study area, namely AF02, AF03, AF05, AF06, RF01, and RF02 (Figure S6 in the supplemental material). These locations were revisited in January 2020 to photograph isolated lichens identified in the initial photographs. The 2020 photographs were georeferenced using ESRI ArcGIS version 10.4.0, based on an overlapping ruler. The older photograph was overlapped to the more recent and georeferenced using at least 10 features of the rock, such as minerals and cracks, around the borders of each thallus (Brabyn et al., 2005; Roof and Werner, 2010). Image transformation due to georeferencing followed a polynomial equation that provided a root mean square error (RMSE), used as an accuracy measure of the georeferencing process (Brabyn et al., 2005). Lichen outlines were hand-traced over both photographs by the same operator, thus creating polygons for each thallus (Roof and Werner, 2010). The maximum inscribed circle for each polygon was automatically extracted using ET GeoWizards version 11.3 software, and the area was automatically determined in ArcGIS. The diameter of each circle was computed from the area. When the sum of the RMSE obtained from georeferencing was higher than the difference between the diameters from different dates, the data were eliminated from further analyses.

\subsection{Optically stimulated luminescence}

Two samples of the sand patch found beneath boulders were collected for age determination by OSL (Figure 3(b)). Sample preparation was carried out under amber-light conditions. Samples were wet sieved to extract the $90-150 \mathrm{~mm}$ fraction and then treated with $\mathrm{HCl}$ to remove carbonates and with hydrogen peroxide to remove organics. Quartz and feldspar grains were extracted by flotation using a $2.7 \mathrm{gm} / \mathrm{cm}^{3}$ sodium polytungstate solution, then treated for 60 minutes in $48 \% \mathrm{HF}$, followed by 30 minutes in $47 \% \mathrm{HCl}$. The sample was then resieved, and the $<90 \mathrm{~mm}$ fraction discarded to remove residual feldspar grains. The etched quartz grains were mounted on the innermost $2 \mathrm{~mm}$ or $5 \mathrm{~mm}$ of $1 \mathrm{~cm}$ aluminum disks using Silkospray. Chemical analyses were carried out using a high-resolution gamma spectrometer. Dose rates were calculated using the method of Aitken (1998) and Adamiec and Aitken (1998) and the updated dose-rate conversion factors of Guerin et al. (2011). The cosmic contribution to the dose rate was determined using the techniques of Prescott and Hutton (1994).

OSL analyses were carried out on Riso Automated OSL Dating System Models TL/OSLDA15B/C and TL/OSL-DA-20, equipped with blue and infrared diodes, using the Single Aliquot Regenerative Dose (SAR) technique (Murray and Wintle, 2000). Early background subtraction was used (Ballarini et al., 2007; Cunningham and Wallinga, 2010). Preheat $\left(240^{\circ} \mathrm{C} / 10 \mathrm{~s}\right)$ and cutheat $\left(220^{\circ} \mathrm{C} / 0 \mathrm{~s}\right)$ temperatures were based upon preheat plateau tests between $180^{\circ}$ and $280^{\circ} \mathrm{C}$. Dose recovery was within 2-sigma of $100 \%$ and thermal transfer within 2-sigma of 0 Gy (Murray and Wintle, 2003). Sample growth curves were below saturation (D/Do < 2; Wintle and Murray, 2006). Optical ages are based upon a minimum of 
50 aliquots (Rodnight, 2008). Individual aliquots were monitored for insufficient count rate, poor quality fits (i.e., higher error in the equivalent dose, De), poor recycling ratio, strong medium versus fast component (Durcan and Duller, 2011), and detectable feldspar. Aliquots deemed unacceptable based upon these criteria were discarded from the dataset before averaging.

\section{Results}

\subsection{Lichen age variables (lichen cover, $\emptyset$, and $\mathrm{A})$}

Increments in the control area generated an increase in the total area covered by lichens, accompanied by a decrease in lichen cover percentage and by an increase in the standard deviation (Figure S19 in the supplemental material). In many cases, these changes were abrupt, rapidly stabilizing after the first one to three grid cell increments. As the control area increased, a higher proportion of rock surface was added in detriment of the area covered by lichens, due to measurements being centered in grid cells with maximum lichen cover. Given that our objective was to find the region of the surface that was primarily colonized, we focused on these first area increments $(100 \mathrm{~mm} \times 100 \mathrm{~mm}$ to $300 \mathrm{~mm} \times 300$ $\mathrm{mm})$, where lichen cover was less diluted and control surfaces with different ages showed a more significant contrast. Also, area increments were limited by smaller control surfaces, such as the cornerstone in the AF07 control point (Figure S13 in the supplemental material). The increase in control area generates a dilution effect due to the inclusion of uncolonized rock surfaces and a lower percentage of lichen cover (Figure 7(a)) (detailed results in the supplemental material). To minimize the dilution, the $100 \mathrm{~mm} \times 100 \mathrm{~mm}$ area was considered as the most representative of surface age. 
(a)

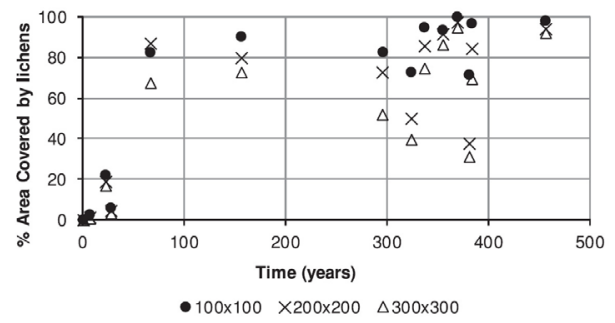

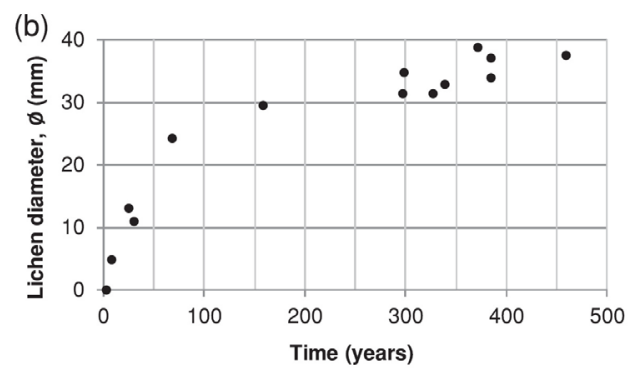

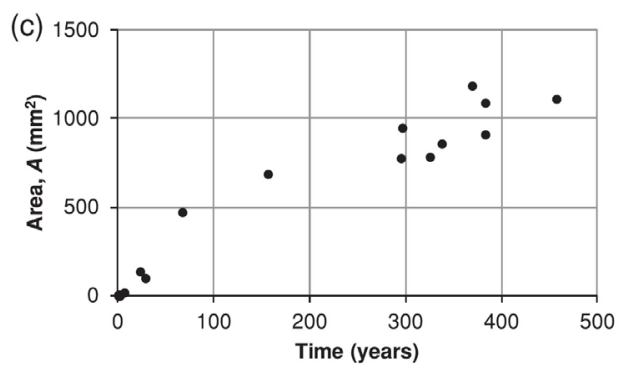

Figure 7. Opegrapha durieui age variables plotted against time: (a) lichen cover considering different control areas; (b) Ø; (c) $A$.

O. durieui reaches a cover of $\sim 70 \%$ after 70 years of exposure (Table 1 and Figure $7(\mathrm{a})$ ). Abnormally high values were observed in two young sampling locations (67 and 157 years old), indicating that this age variable is not strictly controlled by surface age. For example, control surfaces AF02 and AF06 are in the same location with contrasting values in lichen cover (AF02 is lower by $11 \%$ despite being 229 years older). We hypothesize that differences are related to either rock slope (vertical in AF02 and $72^{\circ}$ in AF06), rock texture (AF02 is coarser), or surface roughness (the AF02 surface is more irregular) (Figures S24-26 and S29 in the supplemental material). These results suggest that lichen cover is not a good age estimator, and this variable was excluded from further analysis. 
Oliveira et al., Progress in Physical GeOgraphy 44 (2020)

Table 1. Surface age, time since exposure, lichen cover, and size in the control surfaces

\begin{tabular}{lccccc}
\hline Control surface & Surface age (calendar age) & Time (years) & Lichen cover $(\%)$ & $\varnothing(\mathrm{mm})$ & $\mathrm{A}\left(\mathrm{mm}^{2}\right)$ \\
\hline RF01 & $2011-2012$ & 1.7 & 0 & 0 & 0 \\
RF02 & $2005-2006$ & 7.6 & 3 & 5 & 20 \\
AF01 & $1980-2000$ & 23.9 & 2 & 13.2 & 137 \\
RF03 & $1980-1989$ & 29 & 6 & 11 & 95 \\
AF02 & $1944-1949$ & 67 & 94 & 24.4 & 468 \\
AF10 & 1793 & 157 & 90 & 29.6 & 688 \\
AF06 & $1657-1777$ & 296 & 82 & 31.4 & 774 \\
AF07 & $1657-1777$ & 297 & - & 34.8 & 951 \\
& & 356 & 94 & - & - \\
AF08 & $1588-1690$ & 324 & 73 & - & - \\
& & 326 & - & 31.6 & 784 \\
AF04 & 1678 & 338 & 95 & 33.0 & 855 \\
AF03 & 1645 & 370 & 100 & 38.8 & 1182 \\
AF09 & 1632 & 382 & 71 & - & - \\
& & 384 & - & 34.0 & 908 \\
AF11 & 1632 & 382 & 97 & - & - \\
& & 384 & - & 37.2 & 1087 \\
AF05 & 1558 & 457 & 98 & - & - \\
& & 458 & - & 37.6 & 1110 \\
\hline
\end{tabular}

O. durieui thalli become visible eight years after surface exposure. Lichen diameter, $\varnothing$, increased at a linear rate of $0.36-0.66 \mathrm{~mm} /$ year (averaging $0.49 \mathrm{~mm} /$ year) up to $~ 70$ years after exposure. Growth rates based on $\varnothing$ decreased pronouncedly afterward to $0.08-0.19$ $\mathrm{mm} /$ year (averaging $0.11 \mathrm{~mm} /$ year) (Table 1 and Figure 7(b)). Lichen diameter does not increase linearly with time and is better described by a logarithmic function. Lichen area, $A$, shows a more steady and constant increase with age, the growth rates averaging 3.18 $\mathrm{mm}^{2} /$ year (Figure 7(c)). No relationship was detected between lichen growth rates and ecological variables (altitude, distance from the coastline, and climatic variables) (Figures S20 and S21 in the supplemental material).

\subsection{Growth models}

Growth models for $\varnothing$ and $A$ are represented in Figures 8(a) and (b), showing $R^{2}$ values of 0.96 and $0.91(P<0.0001)$, respectively, which indicates the high goodness of fit of both models. The high correlation and the absence of a relationship with ecological variables suggest that the latter plays a minor role in lichen growth and that $\varnothing$ and $A$ can be used as age estimators. 
(a)

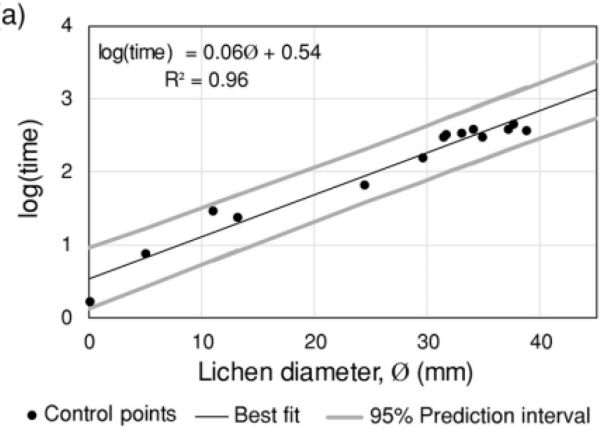

(b)

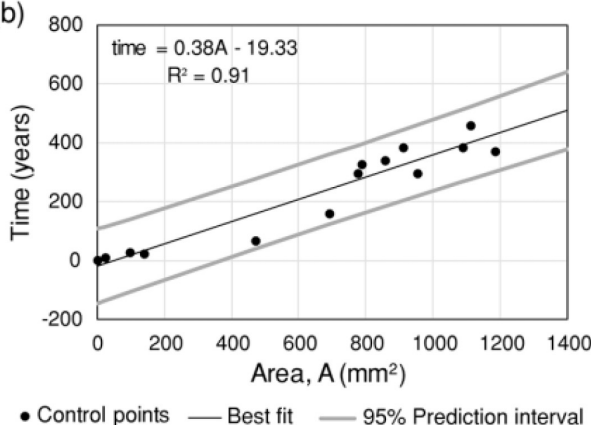

(c)

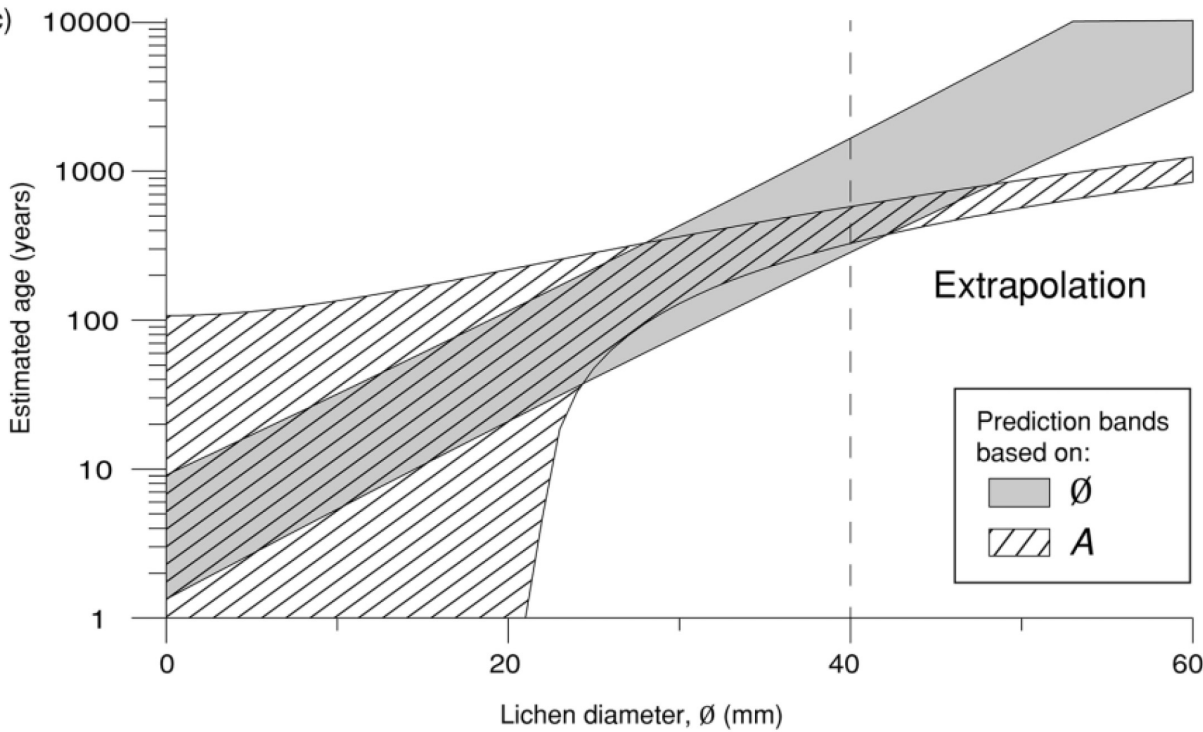

Figure 8. (a) $\varnothing$ and (b) $A$ best fit and 95\% prediction intervals. (c) Prediction bands for the $\varnothing$ and $A$ models.

$R^{2}$ values obtained for the $\varnothing$-based model may suggest that it performs better and is the best age estimator. Furthermore, prediction bands for lower $\varnothing$ are much narrower than those for the $A$ model (Figure 8(c)). However, due to the exponential relationship between time and $\varnothing$, the amplitude of prediction intervals becomes increasingly high for larger sizes, in cases doubling the magnitude of predicted ages (Figure 8(c)). In contrast, at ages of about 200 years and higher, amplitudes of prediction intervals based on $A$ remain around 235 years, while those based on $\varnothing$ continue to increase.

\subsection{Direct measurement of lichen growth}

Thalli monitored for lichen growth are shown in Figures S22 to S30 in the supplemental material (data in the Appendix). Manny lichens, especially the largest, were coalescing and were excluded to avoid competitive restrictions in lichen growth. As a result, there is a higher frequency of measurements in smaller thalli $(<10 \mathrm{~mm})$. Only three thalli were measured in the oldest control point, AF05, all of them missing apothecia and showing evidence 
of being affected by fungi, having also decreased in size from 2016 to 2020 . We believe that most thalli covering this surface are dead, possibly due to changes in environmental conditions (e.g., temperature, moisture, atmospheric pollution). Dead lichens had been detected in 2013, but their frequency increased significantly since then. The direct growth rates measured in the AF05 control surface are not representative of active thalli and were excluded from the dataset. Overall, 64 thalli were measured, from which 18 presented a georeferencing RMSE higher than changes in lichen diameter, having also been excluded. This exclusion affected all lichen sizes but eliminated most of the largest monitored thalli, with only one remaining (Figure S31 in the supplemental material).

Growth rates show an increasing trend with thalli size for smaller lichen thalli $(<10$ $\mathrm{mm})$, ranging from $0.03 \mathrm{~mm} /$ year $\left(0.10 \mathrm{~mm}^{2} /\right.$ year $)$ to $0.74 \mathrm{~mm} /$ year $\left(14.18 \mathrm{~mm}^{2} /\right.$ year $)$ (Figures 9 (a) and (b)). The largest thalli, measuring $26.12 \mathrm{~mm}\left(535.95 \mathrm{~mm}^{2}\right)$, presented a meager growth rate of $0.09 \mathrm{~mm} /$ year $\left(3.64 \mathrm{~mm}^{2} /\right.$ year). The best fit function is a second-order polynomial, with an $R^{2}$ of 0.71 for $A$ and of 0.19 for $\varnothing$. By removing the larger thallus, the best fit function becomes linear for both variables $(\varnothing$ and $A$ ), again more evident for $A$ (Figure 9(c)). 

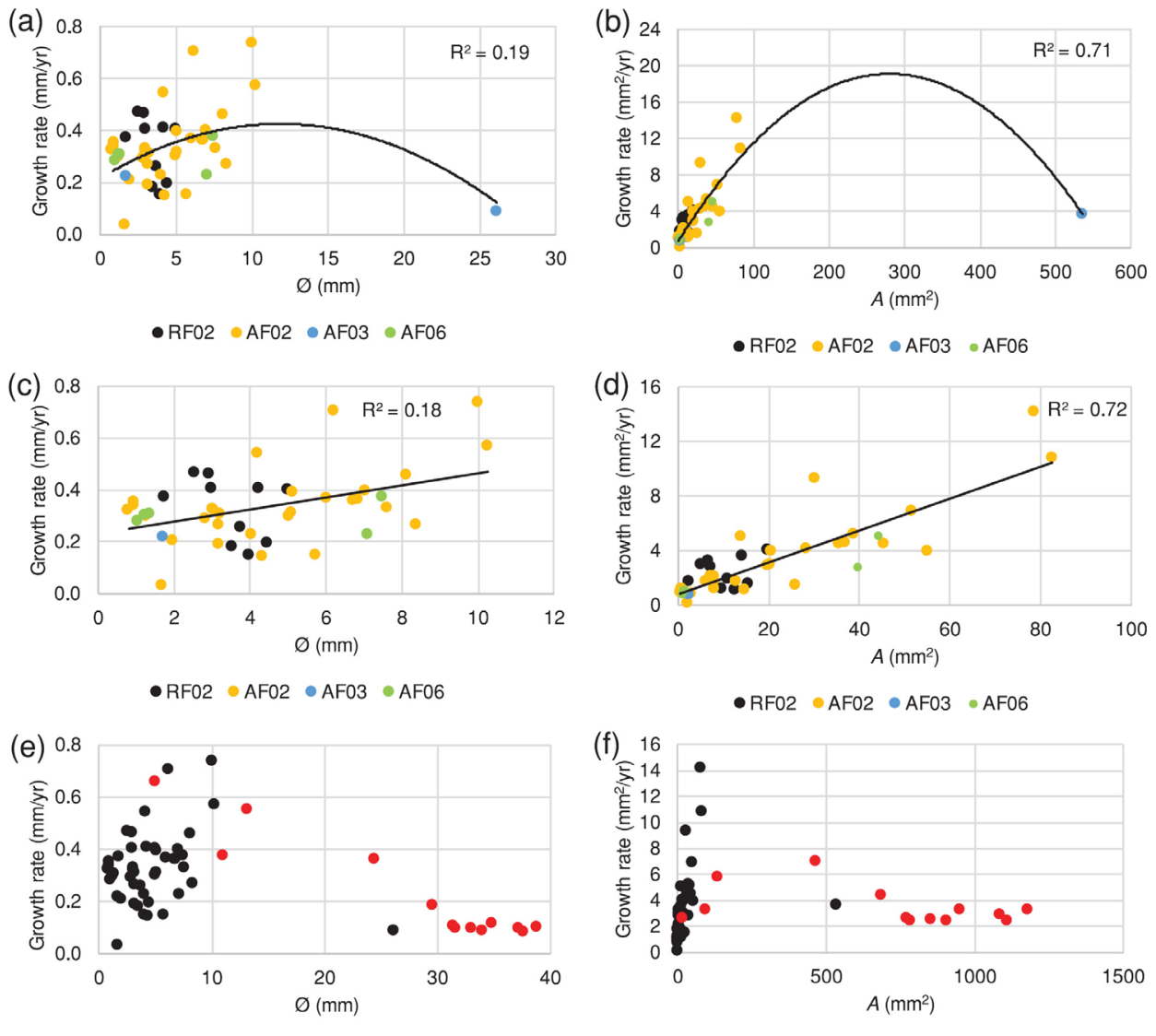

- Direct measurement $\quad$ Indirect measurement

- Direct measurement $\quad$ Indirect measurement

Figure 9. Growth rates plotted against lichen size. Direct growth rates and best fit second polynomial based on (a) $\varnothing$ and (b) $A$. (b) Direct growth rates and best linear fit with the exclusion of the largest thallus based on (c) $\varnothing$ and (d) $A$. (e) Direct and inferred growth rates based on (e) $\varnothing$ and (f) $A$.

The comparison of direct and inferred growth rates confirms the distinct behavior between smaller and larger thalli (Figures 9(e) and (f)). Indirect growth rates of larger thalli $\left(\varnothing>30 \mathrm{~mm}\right.$ or $\left.A>700 \mathrm{~mm}^{2}\right)$ reach a constant value of $\sim 0.09 \mathrm{~mm} /$ year and $\sim 4 \mathrm{~mm}^{2} /$ year for $\varnothing$ and $A$, respectively. However, indirect growth rates of younger thalli are slightly lower than for direct measurements, especially for $A$. Further validation of the growth models was based on the identification of lichens in an originally uncolonized rock-fall surface (RF01: 2011-2012) (Figure S22 in the supplemental material), indicating an establishment period under eight years, contained within prediction intervals of both $\varnothing$ and $A$ models.

\subsection{Age estimation of the boulder deposit}

OSL age estimation of the marine sand found beneath boulders is presented in Table 2. Determination of average De values was carried out using the Minimum Age Model (Galbraith et al., 1999) because the De distribution (asymmetric distribution; decision table of 
Bailey and Arnold, 2006) indicated that it was more appropriate than the Central Age Model (Galbraith et al., 1999). Results for both the Minimum and Central Age Models are further presented in the supplemental material. Samples have an estimated age of $230 \pm 20$ and $290 \pm 50$ years, the marine sand having been deposited between 1674 and 1804 .

Table 2. Optically stimulated luminesce (OSL) dating results when applying the Minimum Age Model (Galbraith et al., 1999) (OSL ages in years before 2014). Error on De is 1 standard error. Age error includes random and systematic errors calculated in quadrature.

\begin{tabular}{cccccccc}
\hline Sample ID & Lab ID & $\begin{array}{c}\text { Burial depth } \\
(\mathrm{m})\end{array}$ & $\begin{array}{c}\text { Dose Rate } \\
(\mathrm{Gy} / \mathrm{ka})\end{array}$ & $\begin{array}{c}\text { De } \\
(\mathrm{Gy})\end{array}$ & $\begin{array}{c}\text { Number of } \\
\text { aliquots }\end{array}$ & Age (a) & $\begin{array}{c}\text { Cal. Age } \\
\text { (CE - current era) }\end{array}$ \\
\hline Q20CxS & UNL4003 & 0.35 & $2.66 \pm 0.10$ & $0.60 \pm 0.06$ & 75 & $230 \pm 20$ & 1784 \\
Q21CxS & UNL4004 & 0.35 & $2.63 \pm 0.10$ & $0.77 \pm 0.13$ & 72 & $290 \pm 50$ & 1724 \\
\hline
\end{tabular}

Information regarding boulder mass, lichen parameters, and estimated ages using the lichen growth models are shown in Table S3 (supplemental material) and depicted in Figure 10. Extrapolated ages of older boulder stabilization are quite different between models, reaching 25 BCE (3165 BCE-1211 CE) with the Ø-based model and 1348 CE (1201-1494 CE) with the $A$-based model. However, interpolated ages roughly overlap between models, the significant difference being the amplitude of prediction intervals. Results from both models indicate that only six to nine boulders were stabilized before 1755 (19\% with the $\varnothing$ based model compared to $28 \%$ with the $A$-based model) and even less overlap the 1755 tsunami (12\% versus 19\%). These include the largest boulders colonized by lichens in the study area, forming a boulder cluster located in the northern sector of the study area (Figure S3(a) in the supplemental material). Results obtained with both models show that most boulders have only recently stabilized, and their final movement cannot be attributed to the 1755 Lisbon tsunami. Furthermore, boulders that have been emplaced far back in time are generally larger than those recently stabilized.
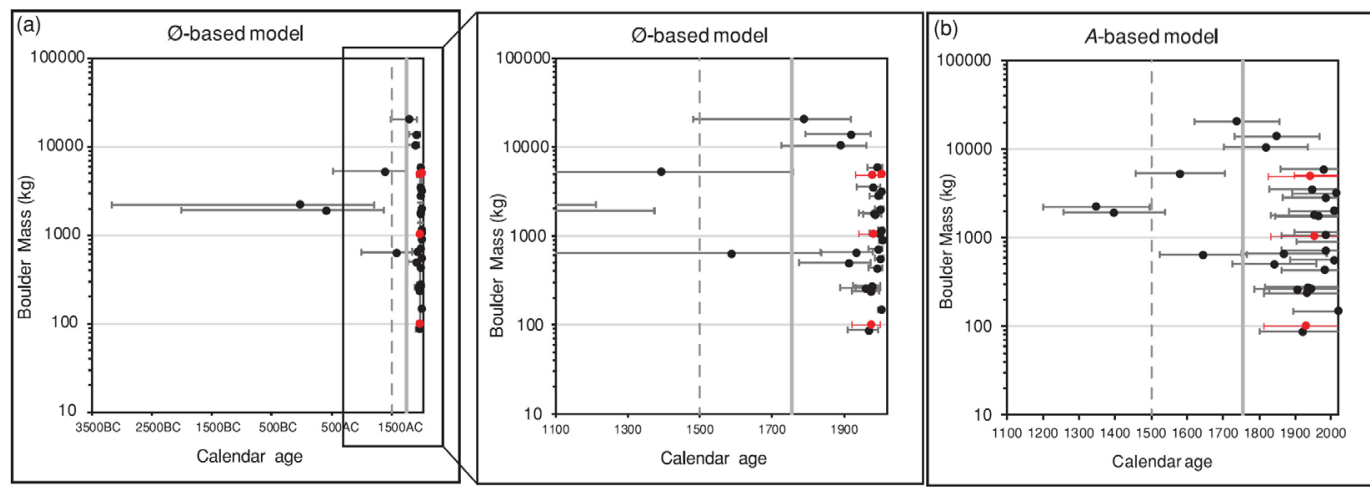

Figure 10. Estimated ages plotted against boulder mass. Lighter dots represent boulders with two overlapping populations. Horizontal error bars represent $95 \%$ prediction intervals. The gray line corresponds to 1755 (date of the Lisbon tsunami). The dashed gray line represents the interpolation limit. 


\section{Discussion}

\subsection{Lichen growth model}

Preliminary results of lichen cover showed abnormally high values in two young control surfaces (67 and 157 years), contrasting with similar or even lower cover obtained for older surfaces (> 290 years). Thus, lichen cover is shown to be dependent on other variables apart from time. The comparison of ecological variables from a 67-year-old fort (AF02) (94\% lichen cover) with an older nearby control surface of 296 years (AF06) (82\% lichen cover) revealed differences in surface slope, rock texture, and surface roughness. We hypothesize that $O$. durieui favors colonization in coarse-grained limestone rocks forming vertical and rough surfaces. A higher affinity to steeper slopes has been reported for lichen species that preferably colonize north-facing rock surfaces (Armstrong, 1974a). Furthermore, higher surface roughness provides a higher complexity of microhabitats and is more effective in water retention when compared to a smoother surface (Armstrong, 1974a). Finally, rocks with coarser textures also retain more moisture than fine-textured rocks (Benedict, 1967). Altogether, the rock type available for colonization in AF02 offers a broader spectrum of microhabitats and higher water retention capability, which could explain differences in the rate of lichen colonization and, consequently, lichen cover percentages. Similar results have been obtained in other regions and with different species, leading to the conclusion that lichen cover is more sensitive to environmental variations than lichen size (Innes, 1986; McCarthy and Zaniewski, 2001).

The logarithmic correlation between $\varnothing$ and time is in line with results described worldwide by Armstrong (2015), Benedict (2009), Bradwell (2001), and Gob et al. (2003), among others. The logarithmic correlation is attributed to changes in the growth rate and is interpreted by Armstrong (1974b) as distinct stages in lichen development. However, the contrast in growth rate between smaller and larger thalli is less apparent when indirectly measured $A$ is considered (red data series in Figure 9(f)). The discrepancy of changes in growth rate within lichen age variables partly results from the quadratic relationship between $A$ and $\varnothing$ (further explained in the supplemental material). This geometrical relation-

ship generates an inflated decrease in lichen growth as it becomes larger/older, further increasing the contrast between growth rates obtained with both age variables.

The choice of variable that better represents lichen growth must be based on biology. In this regard, increases in the size of crustose lichens occur along an area due to marginal growth and in thickness, volume, or mass (cf. Armstrong, 1974b; Clark et al., 2000; Hill, 1981; Máguas and Brugnoli, 1996; Seminara et al., 2018). So, in what concerns growth in two dimensions, the area is a more realistic representation of lichen growth when compared to diameter. Area measurements have been considered as more precise than singleaxis measurements, as they include growth around the entire perimeter of the thallus (Roof and Werner, 2011). Different radii contribute to growth at different times, especially when thalli are not perfectly circular (Matthews and Trenbirth, 2011). Consequently, irregular but significant changes occurring along the perimeter of a thallus are not incorporated in lichen growth measurements when changes in diameter are considered (Roof and Werner, 2011). 
Our observations show that lichen growth rates change with lichen size, linearly increasing up to a point and then decreasing until reaching a constant value. However, evidence of decreasing growth rates based on our dataset of direct measurements is weak, involving only one thallus, the relationship being perfectly linear if the larger thallus is excluded (Figures 9(c) and (d)). Similar observations were reported by Roof and Werner (2011) and attributed to the scarcity of isolated larger thalli and consequent poor constraint of growth rates. Regardless, the polynomial behavior of directly measured lichen growth against size has been reported in several works on crustose lichens (e.g., Bradwell and Armstrong, 2007; Matthews and Trenbirth, 2011). These changes in growth rate are attributed to different phases of growth in the juvenile phase (increasing growth rates), maturation (constant high growth rates), and maturity/senescence (declining to constant low growth rates) (Armstrong, 1974a; Bradwell and Armstrong, 2007).

The linear increase in the size of smaller thalli is more evident for directly measured lichen growth (increase by factor of 150) than for interpolated lichen growth (increase by factor of 3) (Figure 9(f)). The mismatch between directand indirect-derived lichen growth rates has been a highly debated issue and attributed to population dynamics. According to Loso and Doak (2006), older lichens are progressively harder to find on older surfaces, so the probability of finding original cohorts decreases over time. In agreement, interpolated growth rates based on lichen size on a surface of known age would be underestimated. Lichen death was frequently observed in control surfaces when comparing photographs 3-6 years apart, attesting a high lichen turnover. Another factor contributing to lower values for the indirectly measured dataset is that it results from averaging five individuals, which inevitably leads to underestimated growth rates. However, this method equally affects control and boulder surfaces, so age estimations based on the models are not compromised.

\subsection{Age estimation of the boulder deposit}

The marine sand found beneath the boulders comprises fine, well-sorted sand, mostly consisting of quartz grains. The Coxos beach sand and sand deposited during storms on the rocky platform comprises moderately to well-sorted coarse sand with bioclasts, and the colluvium consists of very poorly sorted medium sand with lithoclasts (Oliveira, 2017). The composition, textural, and morphoscopic characteristics of the sand patch contrast with present-day sediments. Furthermore, grain size characteristics of the sand patch are compatible with sediments found in the nearshore, mostly comprising patches of moderately sorted and negatively skewed sand within rocky outcrops (cf. Balsinha, 2008). We hypothesize that the sand fraction from the sand patch was sourced offshore from the closure depth of storms reaching the study area. Ultimately, present-day transport inland and deposition of sediments located offshore from the closure depth could be associated with a tsunami inundation. Since OSL ages perfectly overlap the 1755 Lisbon tsunami and historical records indicate that this event reached a minimum inundation height of $5 \mathrm{~m}$ in this region (cf. Oliveira, 2017), the marine sands may be tsunami-related. The asymmetric shape of the dose distributions in OSL age estimation of onshore sand deposits is frequently interpreted as insufficient light exposure for complete bleaching during the rapid transport and deposition during these events (e.g., Cunha et al., 2010; Fruergaard et al., 
2013; Sawakuchi et al., 2012). Although this occurs for both storm- and tsunami-related deposits, for the former, they are described in progradational shorelines, in which the amount of sediment available for transport facilitates incomplete bleaching (Fruergaard et al., 2013; Sawakuchi et al., 2012). This is not the case for the sand-starved rocky shoreline under analysis. It is more likely that the sand patch was deposited by the 1755 tsunami, which raises the possibility that this inundation has reached the study area. Consequently, the deposition of the boulders over the sand patch must be either coeval or subsequent to the 1755 tsunami.

Age estimation using lichenometry provides a minimum age of boulder emplacement and/or reworking. The distinction between both cases can only be tentatively made when there is evidence of lichen death and regrowth (e.g., the existence of overlapping distinct populations). Over $72 \%$ of dated boulders have reached a stable position long after the 1755 tsunami. No other tsunami reaching the western Portuguese coastline in the past 1000 years could generate the movement of supratidal boulders (cf. Andrade et al., 2016). There is no guarantee that $91 \%$ of these rock boulders (9\% were emplaced before 1755) were not placed on the rocky platform by the 1755 tsunami inundation and have been moving since then due to inundations related to storm events. However, the remaining $9 \%$ must have been transported by storms.

Furthermore, boulder detachment from the edges of the platforms occurred along the study area during the storms of 2013/2014. In several locations, boulders up to $13 \mathrm{t}$ could be traced back to their original location in the platform and cliff edges (Oliveira et al., 2020). These observations are meager when compared to the maximum boulder size of $620 \mathrm{t}$ moved by the same storms in Ireland (Cox et al., 2018). Boulder dislodgement from the edge of cliffs and rocky platforms is facilitated by the presence of embayments and overhanging configurations of impacted cliffs (Canelas et al., 2014). The joint-bounded protruding limestone layers in the upper geological units, together with the natural indentations in the lower rocky platform, provide the optimal morphological conditions for boulder detachment and emplacement over the structural surface. This interpretation agrees with the spatial pattern in boulder size observed in the study area, showing larger boulders preferably located inland of indentations.

The dynamic character of this coastline probably contributes to the low number of colonized boulders in this deposit. Colonization of boulders by O. durieui was mostly found in the middle of more developed and stable boulder ridges. Closer to the platform edge, the absence of $O$. durieui could be associated with the frequency in boulder movement together with the direct and frequent effect of sea spray, where other lichen species grow. Closer to the inner edge of the platform, stabilization is compromised by the cover of sediments from the colluvium transported by gravity and surface runoff.

Ultimately, boulder movement by storms in this rocky coastline must have been persistent since at least 6000 calendar years BP, after the sea level stabilized close to its present position (Cearreta et al., 2007). Larger boulder size, together with the higher elevation and distance from the coastline, makes removal by lower-energy waves less probable, the largest/ least accessible boulders remaining immobile over the structural platforms. In agreement, the existence of only a few boulders older/coeval to 1755, which are also generally larger, strongly suggests that erosion has played an essential role in this location. Given the 
presence of both tsunami and storm events, the movement of rock particles can be associated with both events having reshaped this coast since sea-level stabilization. However, the high frequency in recent boulder stabilization strongly suggests a storm origin for most of the deposit. The highest energy events, which include storms and tsunamis, bear the potential to emplace the largest boulders $(>10 \mathrm{t}$ ). All other smaller rock particles having been entrained and deposited by more common storm waves, only to be later moved by subsequent events, remain unaltered over the structural platforms during a residence period rarely exceeding 200 years. An alternative explanation to the scarcity of boulders older than the 1755 event is that the tsunami inundation imparted an erosive signature in this location and that boulders previously placed by storms were removed by the tsunamirelated continuous and persistent flow over the structural platforms.

The location and complex organization of boulder accumulation described herein show striking similarities with known storm boulder deposits along the rocky western coast of Europe (e.g., Cox et al., 2012; Etienne and Paris, 2010; Hall et al., 2006; Hansom and Hall, 2009). Similarities include the organization of the boulders in ridges and clusters with imbricated boulders, the location on top of rocky cliffs, and size-grading inland. In contrast, boulder deposits related to contemporary tsunamis mostly comprise boulder fields showing no organization or grading inland (Etienne et al., 2011). These similarities further support the storm-origin hypothesis and contrast with the attribution of other boulder deposits in Portugal to paleotsunamis, solely based on their size (10-20 t) and height above the reach of storm waves ( 12 m amsl) (Scheffers and Kelletat, 2005). The reassessment of these and other deposits could have important implications in risk assessment and for coastal management.

\section{Conclusions}

By using control points with similar climatic variables, near-vertical surfaces facing north, isolated thalli, and measurements by a single operator, and by avoiding inheritance, we have successfully constructed a lichen growth model validated by direct measurements. The model provides a measure of uncertainty that incorporates fluctuations in growth rates resulting from several possible factors, such as uncertainties in age determinations, environmental changes, and the period of lichen colonization. Wide prediction intervals are related to the low number of control points. However, given that our main objective was to estimate the age of boulder stabilization to clarify the origin of the Coxos boulder deposit (tsunami versus storm), uncertainties of $\sim 235$ years for the $A$-based model are sufficiently low to provide an answer.

The model allowed estimating the age of exposure, including uncertainty intervals, of carbonate-based rocks near the coastline, where other techniques could not be applied. Ultimately, it demonstrates that many problems associated with lichenometry mentioned in the literature arise from misuses of the technique rather than lack of scientific grounds for its use. It further demonstrates that many source errors associated with lichenometry can be minimized with adequate sampling designs. Finally, the proposed model retains the well-appreciated characteristics associated with lichenometry, such as its simplicity and being cost effective, quick to apply, and nondestructive. 
Transference of this model to other locations is not advised without model validation with local measurements, preferably based on indirect measurements, as they incorporate regional ecological changes, for example, temperature, precipitation, and pollution. An additional limitation to the use of indirect lichen growth curves is that they represent the size of lichens before measurement and, if applied to later studies, will not include changes in the interim period (Innes, 1985). Furthermore, the application of this model is limited to limestone surfaces that have been exposed in the past 500 years.

We demonstrate that the significant decrease observed in lichen growth rates based on diameter is, in part, an inheritance of the quadratic relationship between the diameter of a circle and its area. Changes in growth rates based on lichen diameter described by several authors and attributed to different growth stages are only slightly observed in the indirect dataset based on the area of the thalli. The area presents a linear relationship with time and changes attributed to senescence, and competitive restrictions are not detected using this parameter. This suggests that the use of O. durieui in lichenometric studies can be further extended in time, given that additional and older control points are added to the model.

The high frequency in boulder stabilization at the study site strongly suggests a stormorigin for this accumulation. These results show that storms can generate these deposits and challenge the interpretation that they were formed during tsunamis. Consequently, the frequency of tsunami events inferred from boulder deposits in the W coast of Portugal, and elsewhere, may be lower than expected. The findings reported in this work agree with recent studies showing that storms reaching the $\mathrm{W}$ coast of Europe generate frequent and significant boulder transport. Finally, the presence of marine sand with ages compatible with the 1755 tsunami inundation strongly suggests that this event reached this location at the height of $9 \mathrm{~m}$ amsl ( $4 \mathrm{~m}$ higher than the assumed value for this region). Finally, the scarcity of boulders older than 1755 could indicate an erosive signature for tsunamis in rocky coastline contexts.

Acknowledgments - The authors would like to acknowledge João Nuno Silva and Mariana Ramos for field work assistance and Paulo Henriques, geologist at the Portuguese National Authority for Civil Protection, for information and photographic records of rock-falls in the Ericeira region. The slope mass-movement inventory used in the identification of rock-falls was a result of the project "Creation and implementation of a Coastal Monitoring System for the jurisdiction area of Administração da Região Hidrográfica do Tejo IP" from Faculdade de Ciências da Universidade de Lisboa/Instituto Dom Luiz/Agência Portuguesa do Ambiente, I.P.

Declaration of conflicting interests - The authors declare no potential conflicts of interest with respect to the research, authorship, and/or publication of this article.

Funding - The authors disclose receipt of the following financial support for the research, authorship, and/or publication of this article: Maria A Oliveira was supported by FCT (Fundação para a Ciência e Tecnologia) through a PhD scholarship (SFRH/BD/66017/2009). The work undertaken was partially supported by IDL (UID/GEO/50019/2013 program), financed by FCT, and also partially supported by the European project NitroPortugal: Strengthening Portuguese research and innovation capacities in the field of excess reactive nitrogen (EU H2020-TWINN-2015 692331). Pedro Pinho was supported by project H2020 BiodivERsA32015104. 


\section{References}

Adamiec G and Aitken M (1998) Dose-rate conversion factors: update. Ancient TL 16(2): 37-50.

Aitken MJ (1998) An Introduction to Optical Dating - The Dating of Quaternary Sediments by the Use of Photonstimulated Luminescence. New York: Oxford University Press.

Almeida J (1946) Roteiro dos monumentos militares portugueses, Vol II Distritos de Aveiro, Coimbra, Leiria e Santarém. Publication by the author, pp. 342 (in Portuguese).

Andrade C, Freitas MC, Oliveira MA, et al. (2016) On the sedimentological and historical evidences of seismic-triggered tsunamis in the Algarve coast of Portugal. In: Duarte J and Schellart W (eds) Plate Boundaries and Natural Hazards Geophysical Monograph 219. Washington, D.C.: American Geophysical Union and John Wiley and Sons, Inc., pp. 219-238.

Aptroot A and van Herk CM (2007) Further evidence of the effect of global warming on lichens, particularly those with Trentepohlia phycobionts. Environmental Pollution 146: 293-298.

Armstrong AR (1974a) The descriptive ecology of saxicolous lichens in an area of South Merionethshire, Wales. Journal of Ecology 62(1): 33-45.

Armstrong RA (1974b) Growth phases in the life of a lichen thallus. New Phytologist 73: 913-918.

Armstrong RA (2004) Lichens, lichenometry and global warming. Microbiologist 5: 32-35.

Armstrong RA (2015) The influence of environmental factors on the growth of lichens in the field. In: Upreti DK, Divakar PK, Shukla V, et al. (eds) Recent Advances in Lichenology. New Delhi: Springer, pp. 1-18.

Armstrong RA (2016) Lichenometric dating (lichenometry) and the biology of the lichen genus Rhizocarpon: Challenges and future directions. Geografiska Annaler: Seria A, Physical Geography 98(3): 183-206.

Bailey RM and Arnold LJ (2006) Statistical modeling of single grain quartz De distributions and an assessment of procedures for estimating burial dose. Quaternary Science Reviews 25: 2475-2502.

Ballarini M, Wallinga J, Wintle AG, et al. (2007) A modified SAR protocol for optical dating of individual grains from young quartz samples. Radiation Measurements 42(3): 360-369.

Balsinha M (2008) Sedimentary dynamics of Portuguese continental shelf between Naza nyon and Ericeira. MSc Thesis, Universidade de Lisboa, Portugal.

Benedict JB (1967) Recent glacial history of an Alpine area in the Colorado Front Range, U.S.A. I. Establishing a lichen-growth curve. Journal of Glaciology 6(48): 817-832.

Benedict JB (2009) A review of lichenometric dating and its applications to archaeology. American Antiquity 74: 143-172.

Beschel RE (1961) Dating rock surfaces by lichen growth and its application to glaciology and physiography (lichenometry). In: Raasch G (ed.) Geology of the Arctic. Toronto: University of Toronto Press, pp. 255-278.

Birkeland PW (1982) Subdivision of Holocene glacial deposits, Ben Ohau Range, New Zealand, using relative-dating methods. Geological Society of America Bulletin 93: 433-449.

Brabyn L, Green A, Beard C, et al. (2005) GIS goes nano: Vegetation studies in Victoria Land, Antarctica. New Zealand Geographer 61: 139-147.

Bradwell T (2001) A new Lichenometric dating curve for Southeast Iceland. Geografiska Annaler. Series A, Physical Geography 83(3): 91-101.

Bradwell T (2004) Lichenometric dating in southeast Iceland: The size-frequency approach. Geografiska Annaler 86A: 31-41. 
Bradwell T and Armstrong RA (2007) Growth rates of Rhizocarpon geographicum lichens: A review with new data from Iceland. Journal of Quaternary Science 22: 311-320.

Broadbent ND and Bergqvist KI (1986) Lichenometric Chronology and archaeological features on raised beaches: Preliminary results from the Swedish North Bothnian coastal region. Arctic and Alpine Research 18(3): 297-306.

Bull WB (2014) Using earthquakes to assess lichen growth rates. Geografiska Annaler: Series A, Physical Geography 96: 117-133.

Canelas R, Oliveira MA, Crespo A, et al. (2014) Mathematical simulation of boulder dislodgement by high-energy marine flows in the western coast of Portugal. In: Geophysical Research Abstracts from the European Geosciences Union General Assembly 2014 (EGU2014), Vol. 16. Vienna: European Geosciences Union, p. 16081.

Carrara P and Andrews J (1975) Holocene glacial/periglacial record: Northern San Juan mountains, southwestern Colorado. Zeitschrift für Gletscherkunde und Glazialgeologie 11: 155-174.

Cearreta A, Alday M, Freitas MC, et al. (2007) Postglacial foraminifera and paleoenvironments of the Melides Laggon (SW Portugal): Towards a regional model of coastal evolution. Journal of Foraminiferal Research 37(2): 125-135.

Clark BM, Mangelson NF, St Clair LL, et al. (2000) Measurement of age and growth rate in the crustose saxicolous lichen Caloplaca trachyphylla using $14 \mathrm{C}$ accelerator mass spectrometry. Lichenologist 32(4): 399-403.

Clauzade G and Roux CI (2002) Likenoj de Okcidenta Europo. Fontainebleau: Association Française de Lichénologie.

Costa AG (1997) Os fortes costeiros de Santa Susana e S. Pedro de Milreu, no concelho de Mafra. Boletim Cultural da Câmara de Mafra 96: 105-132 (in Portuguese).

Costa PJ, Andrade C, Freitas MC, et al. (2011) Boulder deposition during major tsunami events. Earth Surface Processes and Landforms 36: 2054-2068.

Coutinho C (1997) Castelos Fortalezas e Torres da região do Algarve. Faro: Algarve em Foco Editora (in Portuguese).

Cox R, Jahn KL, Watkins OG, et al. (2018) Extraordinary boulder transport by storm waves (west of Ireland, winter 2013-2014), and criteria for analysing coastal boulder deposits. Earth-Science Reviews 177: 623-636.

Cox R, Zentner DB, Kirchner BJ, et al. (2012) Boulder ridges on the Aran islands (Ireland): Recent movements caused by storm waves, not tsunamis. The Journal of Geology 120: 249-272.

Cunha PP, Buylaert J-P, Murray AS, et al. (2010) Optical dating of clastic deposits generated by an extreme marine coastal flood: The 1755 tsunami deposit in the Algarve (Portugal). Quaternary Geochronology 5: 329-335.

Cunningham AC and Wallinga J (2010) Selection of integration time intervals for quartz OSL decay curves. Quaternary Geochronology 5(6): 657-666.

Darvill CM (2013) Cosmogenic buclide analysis. In: Cook SJ, Clarke LE and Darvill CM (eds) Geomorphological techniques (Online Edition). London: British Society for Geomorphology.

Decaulne A (2016) Lichenometry in Iceland, results and application. Géomorphologie: Relief, Processus, Environnement 22(1): 77-91.

Direção Geral dos Edifícios e Monumentos Nacionais (1953) Forte da Berlenga. Boletim da Direção Geral dos Edificios e Monumentos Nacionais, 74 (in Portuguese).

Direção Geral dos Edifícios e Monumentos Nacionais (1960) Monumentos de Sagres. Boletim da Direção Geral dos Edifícios e Monumentos Nacionais, 100 (in Portuguese). 
Durcan JA and Duller GAT (2011) The fast ratio: A rapid measure for testing the dominance of the fast component in the initial OSL signal from quartz. Radiation Measurements 46(10): 1065-1072.

Etienne S, Buckley M, Paris R, et al. (2011) The use of boulders for characterizing past tsunamis: lessons from the 2004 Indian Ocean and 2009 South Pacific tsunamis. Earth Science Reviews 107: 76-90.

Etienne S and Paris R (2010) Boulder accumulations related to storms on the south coast of the Reykjanes Peninsula (Iceland). Geomorphology 114: 55-70.

Fick SE and Hijmans RJ (2017). Worldclim 2: New 1-km spatial resolution climate surfaces for global land areas. International Journal of Climatology 37: 4302-4315.

Foulds SA, Griffiths HM, Macklin MG, et al. (2014) Geomorphological records of extreme floods and their relationship to decadal-scale climate change. Geomorphology 216: 193-207.

Fox J and Weisberg S (2011) An R Companion to Applied Regression. Thousand Oaks: SAGE.

Freund RJ, Wilson WJ and Sa P (2006) Regression Analysis: Statistical Modeling of a Response Variable. 2nd ed. Burlington: Academic Press.

Friedl T and Büdel B (2008) Photobionts. In: Nash TH III (ed.) Lichen Biology. New York: Cambridge University Press, pp. 9-26.

Fruergaard M, Andersen TJ, Johannessen PN, et al. (2013) Major coastal impact induced by a 1000year storm event. Scientific Reports 3: 1051.

Galbraith RF, Roberts RG, Laslett GM, et al. (1999) Optical dating of single and multiple grains of quartz from Jinmium Rock Shelter, Northern Australia: Part I, experimental design and statistical models. Archaeometry 41: 339-364.

Garibotti IA and Villalba R (2017) Lichenometric dating using Rhizocarpon subgenus Rhizocarpon in the Patagonian Andes, Argentina. Quaternary Research 71: 271-283.

Gob F, Petit F, Bravard JP, et al. (2003) Lichenometric application to historical and subrecent dynamics and sediment transport of a Corsican stream (Figarella River, France). Quaternary Science Reviews 22: 2111-2124.

Guerin G, Mercier N and Adamiec G (2011) Dose-rate conversion factors: Update. Ancient TL 29: 5-8.

Hall A, Hansom J, Williams D, et al. (2006) Distribution, geomorphology and lithofacies of cliff-top storm deposits: Examples from the high energy coasts of Scotland and Ireland. Marine Geology 232: 131-155.

Hansen ES (2008) The application of lichenometry in dating of glacier deposits. Geografisk TidsskrifDanish Journal of Geography 108: 143-151.

Hansom JD and Hall AM (2009) Magnitude and frequency of extra-tropical North Atlantic cyclones: A chronology from cliff-top storm deposits. Quaternary International 195: 42-52.

Hill DJ (1981) The growth of lichens with special reference to the modelling of circular thalli. Lichenologist 13(2): 265-287.

Hurst MD, Rood DH and Ellis MA (2017) Controls on the distribution of cosmogenic 10Be across shore platforms. Earth Surface Dynamics 5: 67-84.

Innes JL (1983) Lichenometric dating of debris-flow deposits in the Scottish Highlands. Earth Surface Processes and Landforms 8: 579-588.

Innes JL (1985) Lichenometry. Progress in Physical Geography 9: 187-254.

Innes JL (1986) The use of percentage cover measurements in lichenometric dating. Arctic and Alpine Research 18(2): 209-216. 
Instituto Hidrográfico (1985-2003) Tabelas de marés capítulo III Informação suplementar sobre mares. Available at: https:/www.hidrografico.pt/recursos/tabmares/2019/TabelaMares_ Vol1_Capitulo3_Info_Suplementar_2019.pdf (accessed 6 November 2015) (in Portuguese).

Jochimsen M (1973) Does the size of lichen thalli really constitute a valid measure for dating glacial deposits? Arctic and Alpine Research 5(4): 417-424.

Jomelli V, Grancher D, Naveau P, et al. (2007) Assessment study of lichenometric methods for dating surfaces. Geomorphology 86: 131-143.

Jonasson C, Kot M and Kotarba A (1991) Lichenometrical studies and dating of debris flow deposits in the high Tatra mountains, Poland. Geografiska Annaler: Series A, Physical Geography 73: 141-146.

Jones B and Hunter IG (1992) Very large boulders on the coast of Grand Cayman: The effects of giant waves on rocky coasts. Journal of Coastal Research 8(4): 763-774.

Kennedy DM, Tannock KL, Crozier MJ, et al. (2007) Boulders of MIS 5 age deposited by a tsunami on the coast of Otago, New Zealand. Sedimentary Geology 200: 222-231.

Loso MG and Doak DF (2006) The biology behind lichenometric dating curves. Oecologia 147: 223229.

Maas GS and Macklin MG (2002) The impact of recent climate change on flooding and sediment supply within a Mediterranean mountain catchment, southwestern Crete, Greece. Earth Surface Processes and Landforms 27: 1087-1105.

Machado JLS (2009) O Forte de S. Miguel Arcanjo, Monumento Histórico-Militar do séc XVII. Lisboa: Edições Colibri/Câmara Municipal da Nazaré (in Portuguese).

Máguas C and Brugnoli E (1996) Spatial variation in carbon isotope discrimination across the thalli of several lichen species. Plant, Cell and Environment 19: 437-446.

Marini L, Nascimbene J and Nimis PL (2011) Large-scale patterns of epiphytic lichens species richness: Photobiont-dependent responses to climate and forest structure. Science of Total Environment 409: 4381-4386.

Marriner N, Kaniewski D, Morhange C, et al. (2017) Tsunamis in the geological record: Making waves with a cautionary tale from the Mediterranean. Science Advances 3(10): e1700485.

Masarik J and Wieler R (2003) Production rates of cosmogenic nuclides in boulders. Earth and Planetary Science Letters 216: 201-208.

Mastronuzzi G, Pignatelli C, Sansó P, et al. (2007) Boulder accumulations produced by the 20th of February, 1743, tsunami along the coast of southeastern Salento (Apulia region, Italy). Marine Geology 242: 191-205.

Mateus MFRC (1999) Fortificações da região de Peniche. MSc Thesis, Universidade de Lisboa (in Portuguese).

Matthews JA and Trenbirth HE (2011) Growth rate of a very large crustose lichen (Rhizocarpon subgenus) and its implications for lichenometry. Geografiska Annaler: Series A, Physical Geography 93(1): 27-39.

McCarrol D, Shakesby RA and Matthews JA (2001) Enhanced rockfall activity during the Little Ice Age: Further lichenometric evidence from a Norwegian talus. Permafrost and Periglacial Processes 12: 157-164.

McCarthy DP (1999) A biological basis for lichenometry? Journal of Biogeography 26: 379-386.

McCarthy DP and Zaniewski K (2001) Digital analysis of lichen cover: a technique for use in lichenometry and lichenology. Arctic Antarctic and Alpine Research 33(1): 107-113.

Mesquita JCV (2000) Sagres um lugar na história e no património universal. Faro: AJEA Edições (in Portuguese). 
Moore DS, McCabe GP and Craig BA (2009) Introduction to the Practice of Statistics. 6th ed. New York: W.H. Freeman and Company.

Muir-Wood R and Mignan A (2009) A phenomenological reconstruction of the Mw November 1st 1755 earthquake source. In: Mendes-Victor LA, Oliveira CS, Azevedo J, et al. (eds) The 1755 Lisbon Earthquake: Revisited. Geotechnical, Geological, and Earthquake Engineering, vol 7. Dordrecht: Springer, pp. 121-146.

Murray AS and Wintle AG (2000) Luminescence dating of quartz using an improved single-aliquot regenerativedose protocol. Radiation Measurements 32(1): 57-73.

Murray AS and Wintle AG (2003) The single aliquot regenerative dose protocol: Potential for improvements in reliability. Radiation Measurements 37(4-5): 377-381.

Nash TH III, Kappen L, Lösch R, et al. (1987) Cold resistance of lichens. In: Peveling E (ed.) Progress and Problems in Lichenology in the Eighties. Bibliotheca Lichenologica 25. Berlin-Stuttgart: J. Cramer, pp. 313-317.

Nimis PL (2016) The Lichens of Italy. A Second Annotated Catalogue. Trieste: EUT, pp. 739.

Nimis PL and Tretiach M (1995) The lichens of Italy-A phytoclimatical outline. Cryptogamic Botany 5: 199-208.

Noller JS and Locke WW (2000) Lichenometry. In: Noller JS, Sowers JM and Lettis WR (eds) Quaternary Geochronology. Washington, D.C.: Wiley Online Library, pp. 261-272.

Nott J (1997) Extremely high-energy wave deposits inside the great barrier reef, Australia: Determining the cause - tsunami or tropical cyclone. Marine Geology 141: 193-207.

Nott J (2000) Records of prehistoric tsunamis from boulder deposits: Evidence from Australia. Science of Tsunami Hazards 18: 3-14.

Oliveira MA (2017) Boulder deposits related to extreme marine events in the western coast of Portugal. PhD Thesis, Universidade de Lisboa, Portugal.

Oliveira MA, Scotto M, Barbosa S, et al (2020) Morphological controls and statistical modelling of boulder transport by extreme storms. Marine Geology 426: 106216.

O'Neal MA and Schoenenberger KR (2003) A Rhizocarpon geographicum growth curve for the Cascade Range of Washington and northern Oregon, USA. Quaternary Research 60: 233-241.

Orwin JF, Mckinzey KM, Stephens MA, et al. (2008) Identifying moraine surfaces with similar histories using lichen size distributions and the u2 statistic, southeast Iceland, Geografiska Annaler: Series A, Physical Geography 90(2): 151-164.

Osborn G, McCarthy D, LaBrie A, et al. (2015) Lichenometric dating: Science or pseudo-science? Quaternary Research 83: 1-12.

Pendleton SL, Briner JP, Kaufman DS, et al. (2017) Using cosmogenic ${ }^{10} \mathrm{Be}$ exposure dating and lichenometry to constrain holocene glaciation in the Central Brooks Range, Alaska. Arctic, Antarctic, and Alpine Research 49(1): 115-132.

Prescott JR and Hutton JT (1994) Cosmic ray contributions to dose rates for luminescence and ESR dating: Large depths and long-term time variations. Radiation Measurements 23(2-3): 497-500.

Proctor MCF (1983) Sizes and growth-rates of thalli of the lichen Rhizocarpon geographicum on the Moraines of the Glacier De Valsorey, Valais, Switzerland. The Lichenologist 15(03): 249-261.

Quaresma AM (2007) Alexandre Massai, a "escola italiana" de engenharia militar no litoral Alentejano (séculos XVI e XVII). Sines: Centro Cultural Emmerico Nunes (in Portuguese).

R Core Team (2017) R: A Language and Environment for Statistical Computing. Vienna: R Foundation for Statistical Computing. 
Ramalho RS, Winckler G, Madeira J, et al. (2015) Hazard potential of volcanic flank collapses raised by new megatsunami evidence. Science Advances 1(9): e1500456.

Remy C, Edwige P-B and Yannick C (2018) Limitations to U/Th dating of reef-platform carbonate boulders produced by high-energy marine inundations in the Tuamotu Archipelago (French Polynesia). Coral Reefs 37: 1139-1155.

Rey J (2007) Stratigraphie séquentielle et séquences de dépôt dans le Crétacé inférieur du Bassin Lusitanien. Ciências da Terra (UNL) Esp VI: 120.

Rindi F and Guiry MD (2002) Diversity, life history, and ecology of Trentepohlia and Printzia (Trentepohliaceae, Chlorophyta) in urban habitats in western Ireland. Journal of Phycology 38: 39-54.

Rixhon G, May SM, Engel M, et al. (2018) Multiple dating approach $\left({ }^{14} \mathrm{C},{ }^{230} \mathrm{Th} / \mathrm{U}\right.$, and $\left.{ }^{36} \mathrm{Cl}\right)$ of tsunamitransported reef-top boulders on Bonaire (Leeward Antilles) - Current achievements and challenges. Marine Geology 396: 100-113.

Roberts SJ, Hodgson DA, Shelley S, et al. (2010) Establishing lichenometric ages for nineteenth- and twentieth-century glacier fluctuations on South Georgia (South Atlantic). Geografiska Annaler 92: 125-139.

Rodnight H (2008) How many equivalent dose values are needed to obtain a reproducible distribution? Ancient TL 26: 3-9.

Roof S and Werner A (2011) Indirect growth curves remain the best choice for lichenometry: Evidence from directly measured growth rates from Svalbard. Arctic, Antarctic, and Alpine Research 43(4): 621-631.

Rosenwinkel S, Korup O, Landgraf A, et al. (2015) Limits to lichenometry. Quaternary Science Reviews 129: 229-238.

Roux C and Egea J (1992) L'Opegraphetum durieui Egea et Roux ass. nov., une association lichénique saxicole-calcicole, halophile. Cryptogamie, Bryologie, lichénologie, 13: 105-115.

Sawakuchi AO, Guedes CCF, DeWitt R, et al. (2012) Quartz OSL sensitivity as a proxy for storm activity on the southern Brazilian coast during the Late Holocene. Quaternary Geochronology 13: 92-102.

Scheffers A and Kelletat D (2005) Tsunami relics on the coastal landscape west of Lisbon, Portugal. Science of Tsunami Hazards 23(1): 3-16.

Scheffers A, Scheffers S, Kelletat D, et al. (2009) Wave-emplaced coarse debris and megaclasts in Ireland and Scotland: Boulder transport in a high-energy littoral environment. The Journal of Geology 117(5): 553-573.

Scheffers AM, Engel M, May SM, et al. (2014) Potential and limits of combining studies of coarseand fine-grained sediments for the coastal event history of a Caribbean carbonate environment. In: Martini IP and Wanless HR (eds) Sedimentary Coastal Zones from High to Low Latitudes; Similarities and Differences. Geological Society of London Special Publications 388: pp. 503-531.

Schneider B, Hoffmann G, Falkenroth M, et al. (2019) Tsunami and storm sediments in Oman: Characterizing extreme wave deposits using terrestrial laser scanning. Journal of Coastal Conservation 23: 801-815.

Seminara A, Fritz J, Brenner MP, et al. (2018) A universal growth limit for circular lichens. Journal of the Royal Society Interface 15: 20180063.

Severino CMM (2014) De Sagres a Tróia Fortalezas 1580-1680. MSc Thesis, Universidade de É vora (in Portuguese).

Silva PFT (2013) O restauro da Fortaleza de Sagres no Estado Novo. VOX MUSEI arte e patrimônio 2(3): 190-198 (in Portuguese). 
Sipman H and Raus T (1999) A lichenological comparison of the Paros and Santorini island groups (Aegean, Greece), with annotated checklist. Willdenowia 29: 239-297.

Sipman HJM and Harrids RC (1989) Lichens. In: Leith H and Werger MJA (eds) Tropical Rainforest Ecosystems. Amsterdam: Elsevier, 303-309.

Smith CW, Aptroot A, Coppins BJ, et al. (2009) Lichens of Great Britain and Ireland. Ashford: British Lichen Society.

Suzuki A, Yokoyama Y, Kan H, et al. (2008) Identification of 1771 Meiwa Tsunami deposits using a combination of radiocarbon dating and oxygen isotope microprofiling of emerged massive Porites boulders. Quaternary Geochronology 3: 226-234.

Terry JP, Oliver GJH and Friess AD (2016) Ancient high-energy storm boulder deposits on Ko Samui, Thailand, and their significance for identifying coastal hazard risk. Palaeogeography, Palaeoclimatology, Palaeoecology 454: 282-293.

Trenbirth HE and Matthews JA (2010) Lichen growth rates on glacier forelands in southern Norway: Preliminary results from a 25-year monitoring programme. Geografiska Annaler: Series A, Physical Geography 92: 19-39.

Trenhaile AS (2018) Shore platform erosion and evolution: Implications for cosmogenic nuclide analysis. Marine Geology 403: 80-92.

Trudgill S, Crabtree R and Walker P (1979) The age of exposure of limestone pavements-a pilot lichenometric study in Co. Clare, Eire. Transactions of the British Cave Research Association 6(1): 10-14.

van Herk CM, Aptroot A and van Dobben HF (2002) Long-term monitoring in the Netherlands suggests that lichens respond to global warming. Lichenologist 34: 141-154.

Vött A, Bruins HJ, Gawehn M, et al. (2019) Publicity waves based on manipulated geoscientific data suggesting climatic trigger for majority of tsunami findings in the Mediterranean-Response to "Tsunamis in the geological record: Making waves with a cautionary tale from the Mediterranean" by Marriner et al. (2017). Zeitschrift für Geomorphologie, Supplementary Issues 62(2): 7-45.

Williams DM and Hall AM (2004) Cliff-top megaclast deposits of Ireland, a record of extreme waves in the North Atlantic-storms or tsunamis? Marine Geology 206: 101-117.

Wintle AG and Murray AS (2006) A review of quartz optically stimulated luminescence characteristics and their relevance in single-aliquot regeneration dating protocols. Radiation Measurements 41(4): 369-391.

Worsley P (1990) Lichenometry. In: Goudie A (ed.) Geomorphological Techniques. New York: George Allen and UNWIN, pp. 302-306. 
Title of Original Article

Estimating the age and mechanism of boulder transport related with extreme waves using lichenometry

\section{Supplementary Material}

\section{The Coxos Boulder deposit}

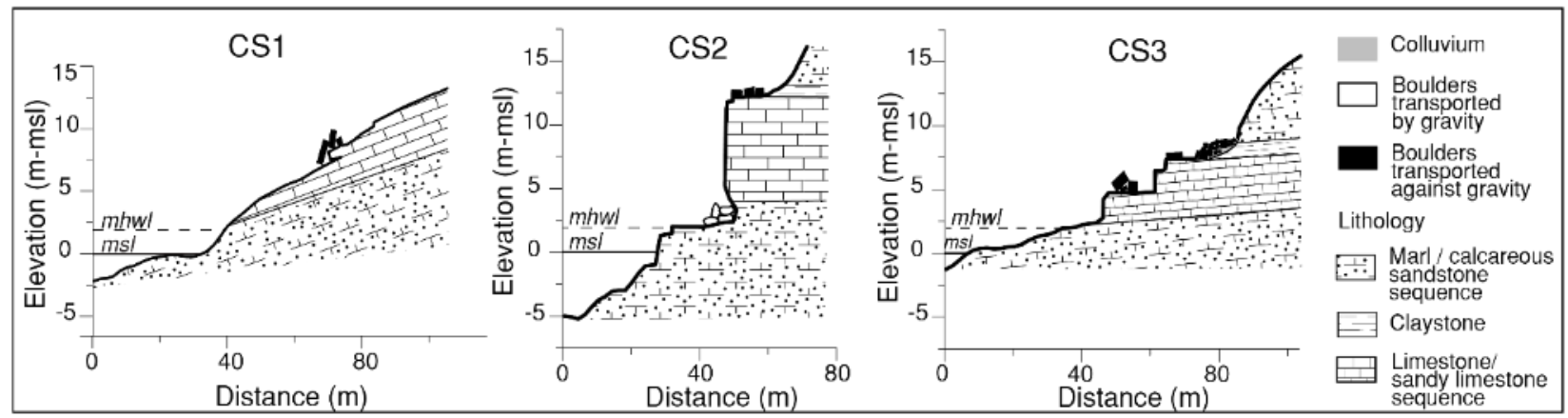

Figure S1: Cross-sections of the study area (see Figure 1a for location)

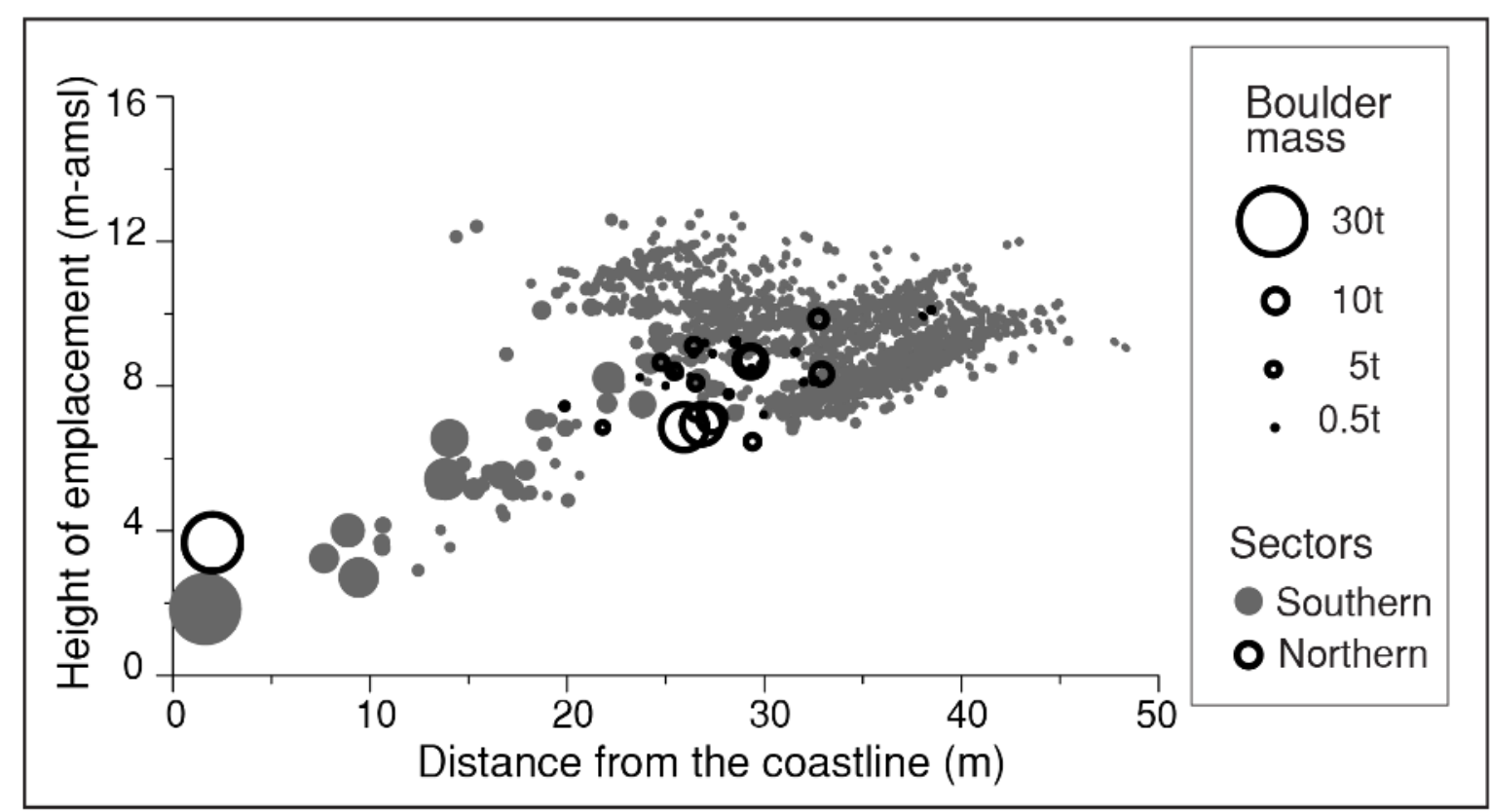

Figure S2: Boulder height of emplacement plotted against distance from the coastline. The size of the circles is based on boulder mass 

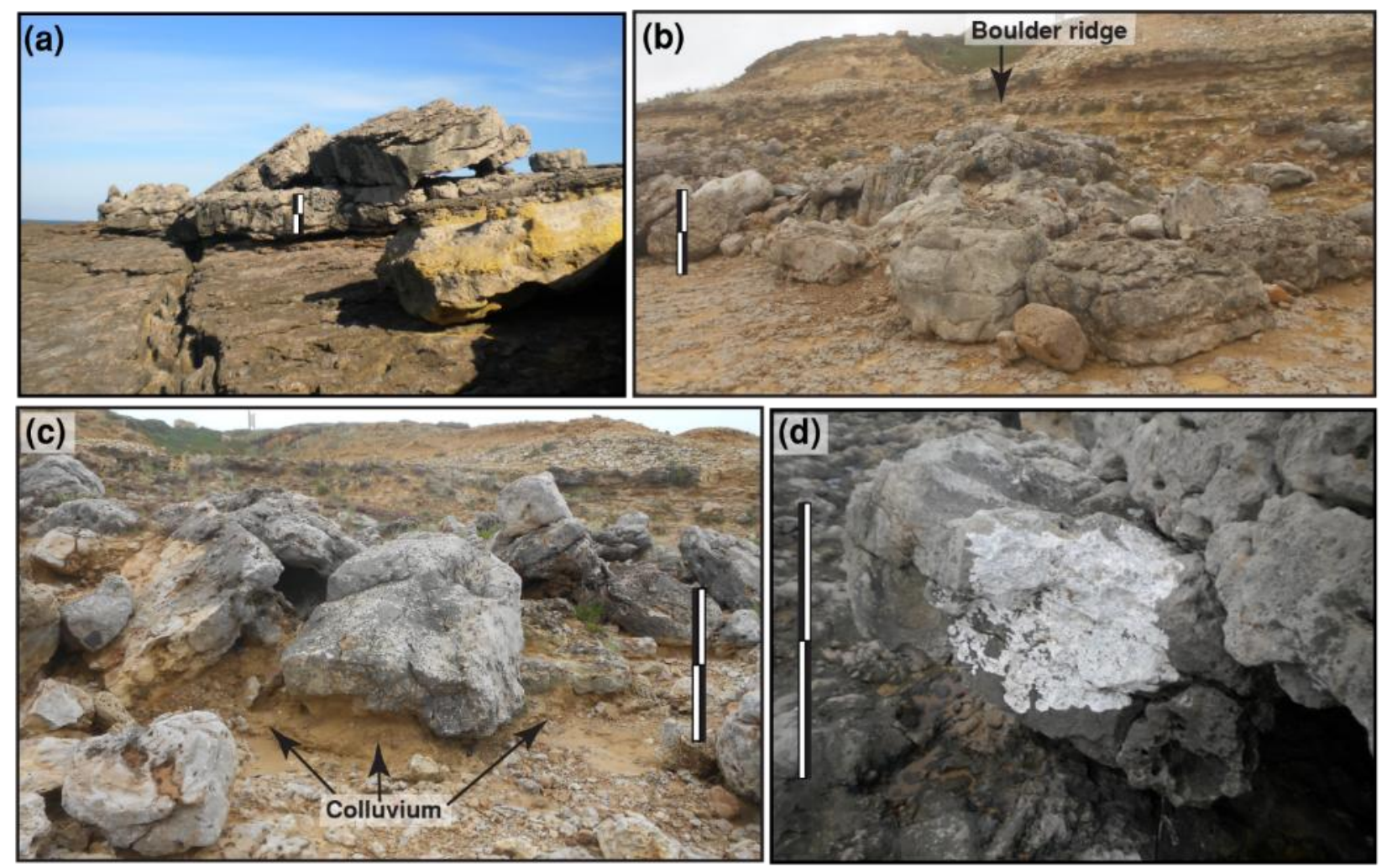

Figure S3: (a) 10-20ton boulders leaning against a bench edge; (b) Boulder ridge; (c) colluvium deposit developing around and partly covering boulders; (d) boulder colonized by the lichen species Opegrapha durieui. Scale corresponds to $\sim 1 \mathrm{~m}$. 
Grain size analysis and morphoscopy of the marine sand patch and sediment sources

Table S1: Grain size data, graphic parameters, and classification of sediment samples

\begin{tabular}{|c|c|c|c|c|c|c|}
\hline Sample & $\begin{array}{c}\text { Graphic Mean } \\
(\mathrm{MZ})(\phi)\end{array}$ & $\begin{array}{c}\text { Inclusive Graphic } \\
\text { Standard } \\
\text { Deviation }\left(\sigma_{\mathrm{I}}\right)(\phi)\end{array}$ & $\begin{array}{l}\text { Inclusive } \\
\text { Graphic } \\
\text { Skewness } \\
\text { (SKI) }\end{array}$ & Kurtosis (KG) & $\begin{array}{c}<63 \mu \mathrm{m} \\
(\%)\end{array}$ & $\begin{array}{l}\text { Heavy } \\
\text { mineral of } \\
\text { the } 0-2 \phi \\
\text { fraction } \\
(\%)\end{array}$ \\
\hline \multirow[b]{2}{*}{ Beach } & 0.47 & 0.38 & 0.12 & 1.04 & \multirow[b]{2}{*}{0.2} & \multirow[b]{2}{*}{12.1} \\
\hline & Coarse sand & Well sorted & $\begin{array}{l}\text { Positive- } \\
\text { skewed }\end{array}$ & Mesokurtic & & \\
\hline \multirow[b]{2}{*}{ Storm } & 0.72 & 0.76 & 0.09 & 1.22 & \multirow[b]{2}{*}{0.9} & \multirow[b]{2}{*}{13.2} \\
\hline & Coarse sand & $\begin{array}{c}\text { Moderately } \\
\text { sorted }\end{array}$ & $\begin{array}{c}\text { Nearly } \\
\text { Symmetrical }\end{array}$ & Leptokurtic & & \\
\hline \multirow[b]{2}{*}{ Colluvium } & 1.87 & 2.47 & -0.60 & 0.72 & \multirow[b]{2}{*}{39.6} & \multirow[b]{2}{*}{2.2} \\
\hline & Medium sand & $\begin{array}{l}\text { Very poorly } \\
\text { sorted }\end{array}$ & $\begin{array}{c}\text { Very } \\
\text { negative- } \\
\text { skewed } \\
\end{array}$ & Platykurtic & & \\
\hline \multirow[b]{2}{*}{ Sand patch } & 2.32 & 1.09 & 0.14 & 1.05 & \multirow[b]{2}{*}{11.2} & \multirow[b]{2}{*}{0.6} \\
\hline & Fine sand & Poorly sorted & $\begin{array}{l}\text { Positive- } \\
\text { skewed }\end{array}$ & Mesokurtic & & \\
\hline
\end{tabular}



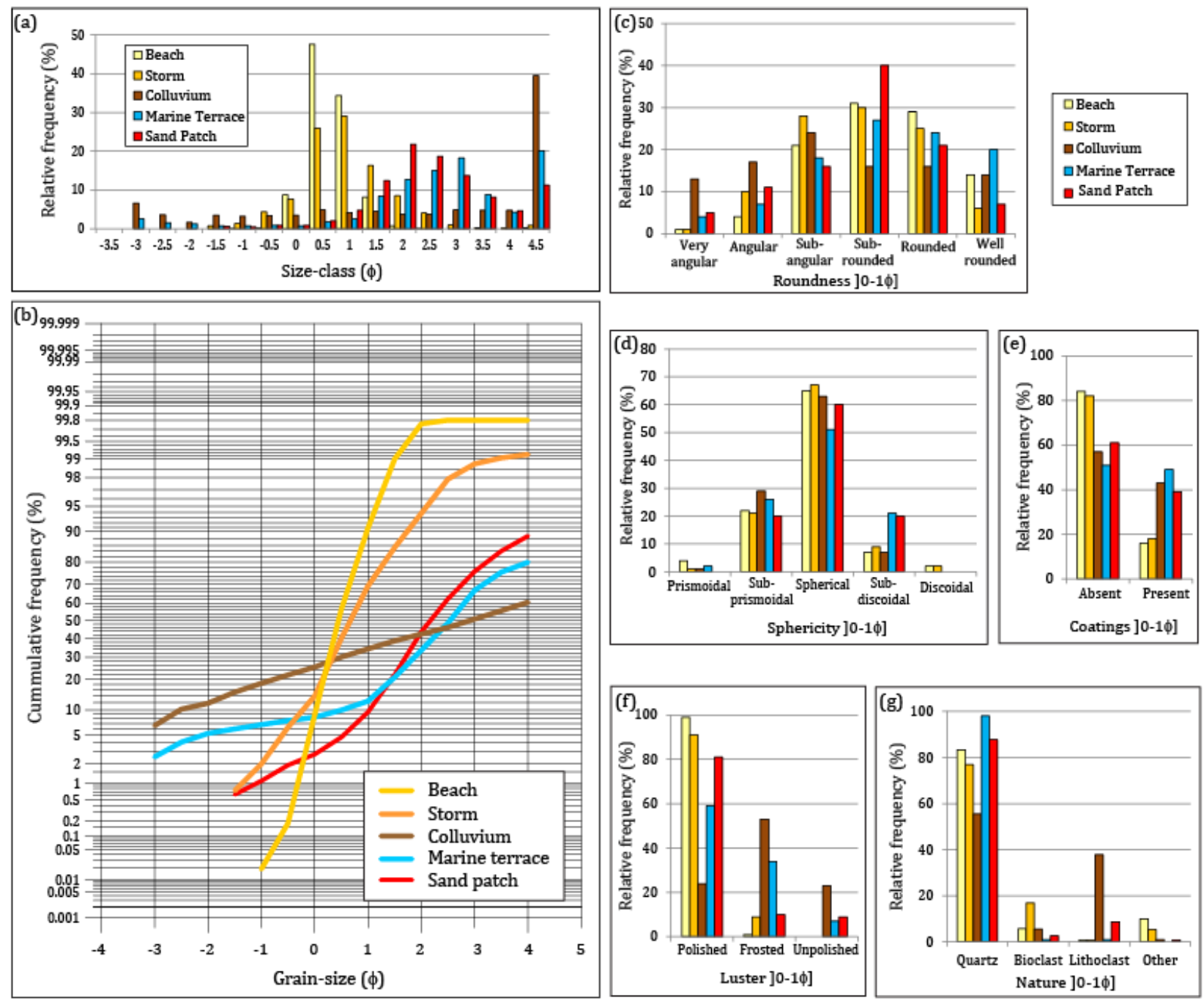

Figure S4: Grain-size and morphoscopy of the marine patch and source sediments in the study area: (a) grain size relative frequency histogram; (b) grain-size cumulative distribution curves. Particle morphology and surface features obtained with morphoscopic analysis of the $0-1 \phi$ fractions: (c) roundness; (d) sphericity; (e) coatings; (f) luster; (g) composition. From Oliveira (2017) 


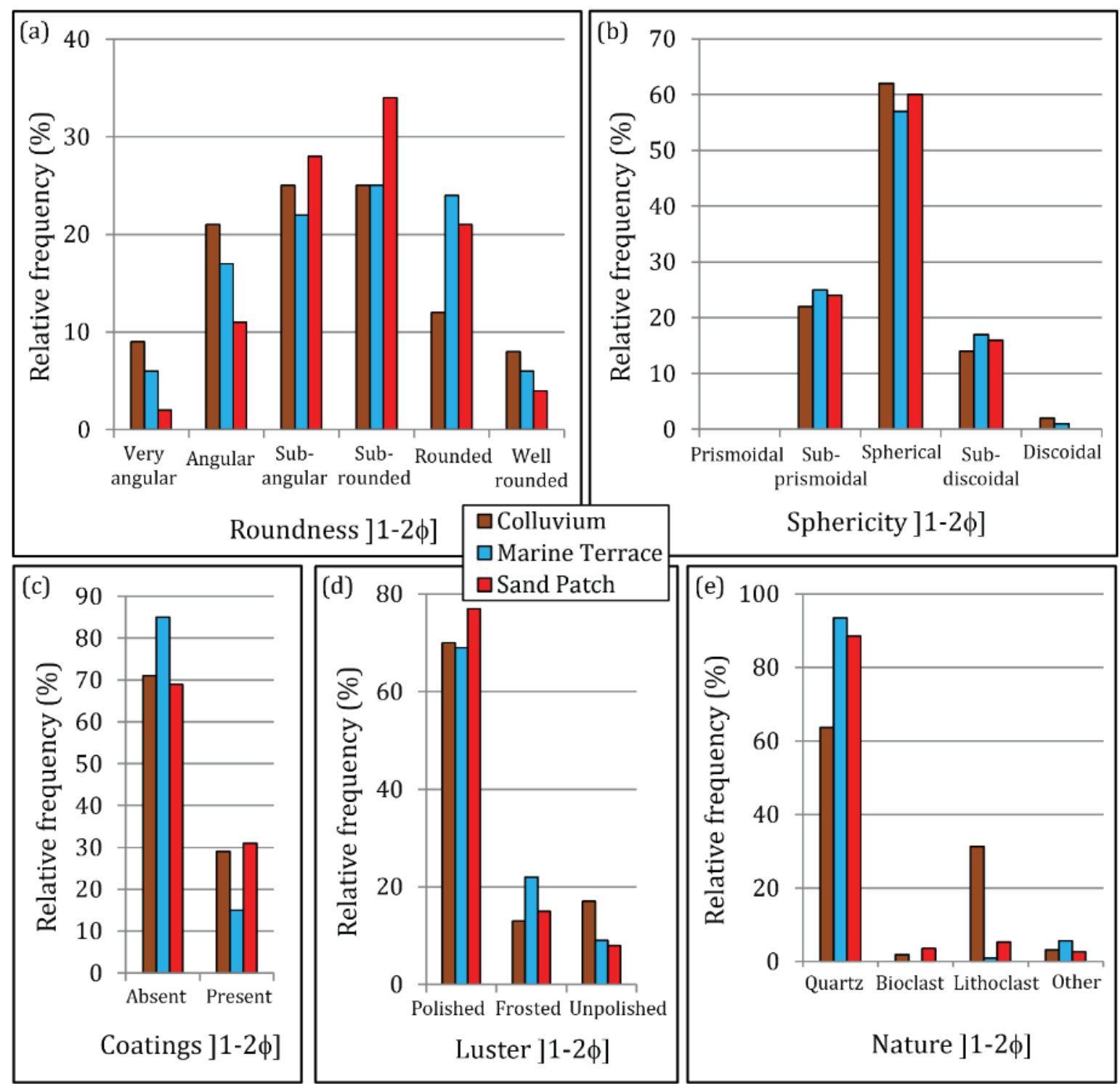

Figure S5: Particle morphology and surface features obtained with morphoscopic analysis of the 1-2 $\phi$ fractions: (a) roundness; (b) sphericity; (c) coatings; (d) luster; (e) composition. From Oliveira (2017) 


\section{Control points used in indirect and direct lichen growth methodologies}

Lichen size and cover were measured in control surfaces with known age of exposure (Figure S6). Direct measurements of lichen growth data in control surfaces are also provided in an excel spreadsheet as supplementary materials.

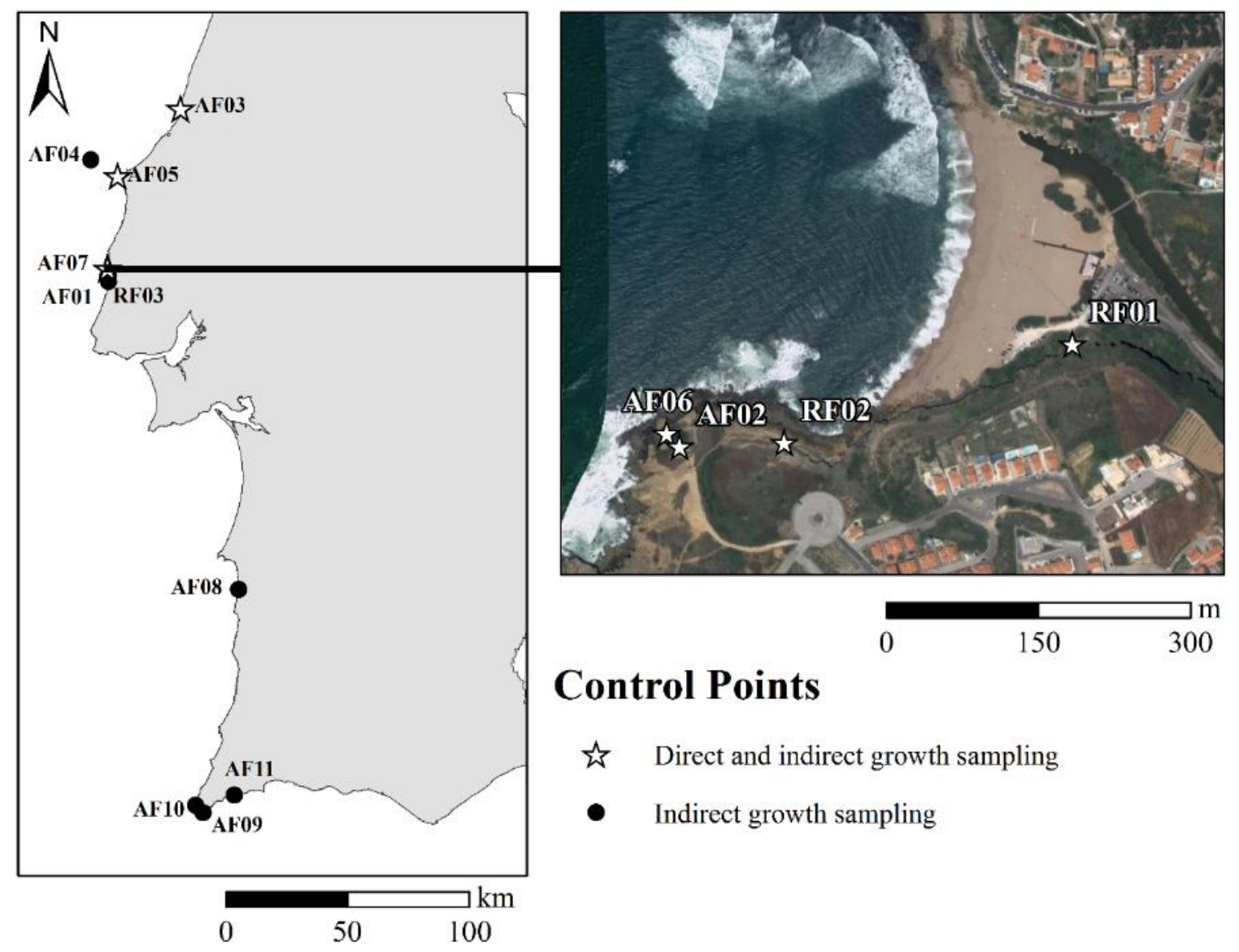

Figure S6: Location of control points where indirect and direct lichen growth were sampled. Maps built with Esri@ ArcMapTM 10.5.1.7333, source of satellite images: Esri,

DigitalGlobe, GeoEye, Earthstar Geographics, CNES/Airbus DS, USDA, USGS, AeroGRID, IGN, and the GIS User Community

\section{AF03 S. Miguel de Arcanjo Fort: 1645}

The AF03 control point is located at an ancient fort named S. Miguel de Arcanjo. The fort was built around 1577 to protect the bay and port from pirates and pillages (Almeida, 1946; Machado, 2009). The earlier and unfinished version of the fort revealed inadequate defensive capabilities. For this reason, the fort was later rebuilt, remodeled and expanded, and reached its current configuration in 1645 (Almeida, 1946; Machado, 2009). Lichens were sampled in the cornerstones of the $\mathrm{N}$-facing wall (surface aspect $330^{\circ} \mathrm{N}$ ) of the fort at $15 \mathrm{~m}$ above mean sea level (amsl) and $24 \mathrm{~m}$ from the coastline (Figure S7). The control 
surface was vertical and comprised of clastic limestone. Lichen size measurements and photographic record for cover measurements were undertaken in 13-11-2015. The site was re-visited in 25-01-2020 to photograph lichen thalli for direct lichen growth measurements.
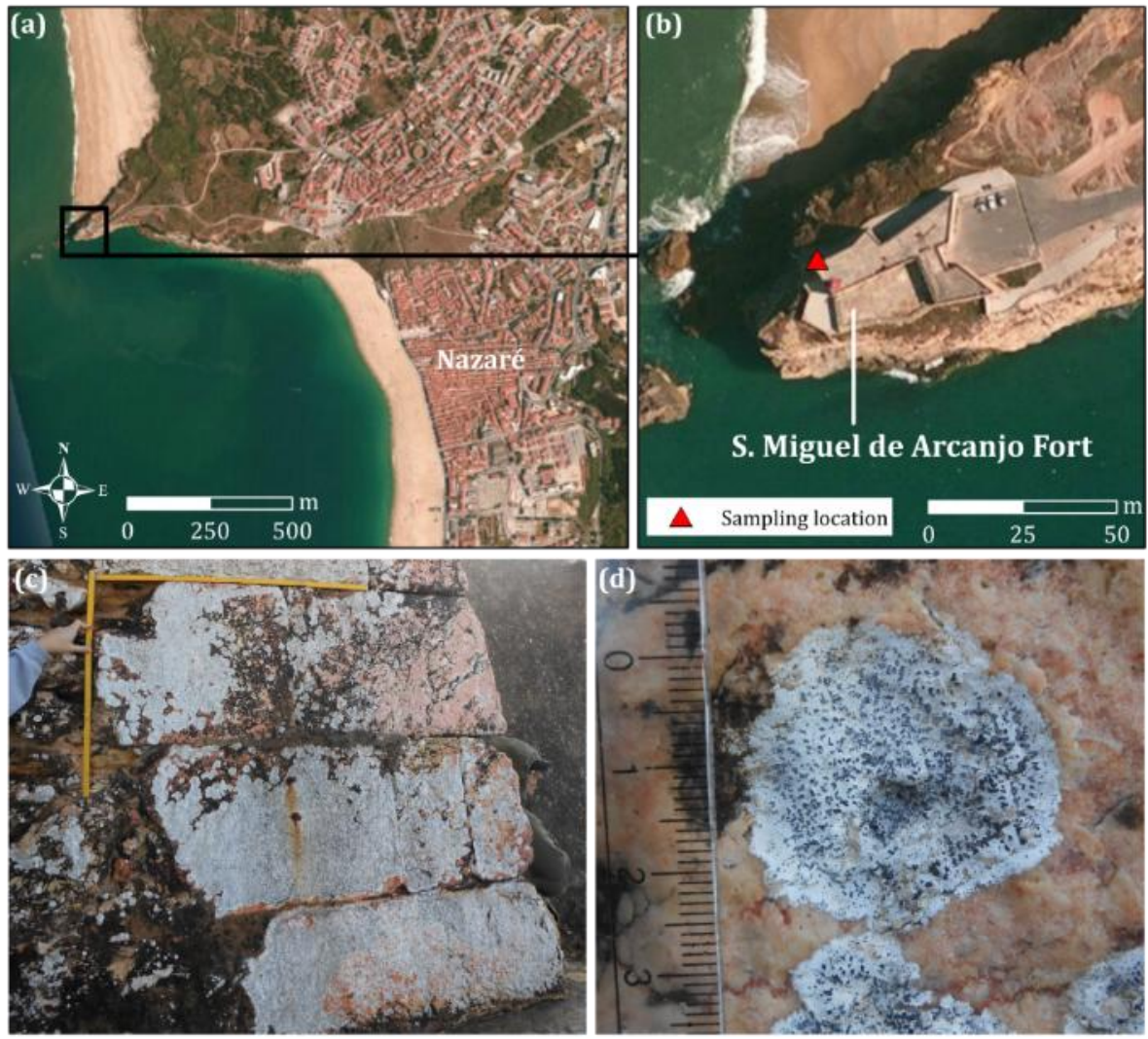

Figure S7: (a) (b) Location of the AF03 control point in S. Miguel de Arcanjo Fort over a satellite image (Maps built with Esri@ ArcMapTM 10.4, source of the satellite image: Esri, Digital Globe, GeoEye, i-cubed, USDA, USGS, AEX, Getmapping, Aerogrid, IGN, IGP, swisstopo, and the GIS User Community).(c) Corner-stones used in lichen cover measurements; vertical scale corresponds to $0.6 \mathrm{~m}$ and horizontal scale to $0.8 \mathrm{~m}$. (d) Detail of a lichen thallus on the corner-stone.

\section{AF04 S. João Baptista Fort: 1678}

AF04 control point is in S. João Baptista Fort on Berlenga Grande island, offshore central Portugal. The fort was built as a convent around 1520. It was abandoned around 1570 and later, in 1640, rebuilt and turned into a fort (Direção Geral dos Edifícios e Monumentos Nacionais, 1953). Since then, S. João Baptista Fort suffered a severe attack and was rebuilt in 1678, as stated in an inscription located over the main door (Direção Geral dos Edifícios e Monumentos Nacionais, 1953). The fort is mainly made of granite, except for the crystalline limestone main door frame, inscription stone, and coat of arms. The door frame comprises a narrow vertical surface facing North (surface aspect of $315^{\circ} \mathrm{N}$ ), at $5 \mathrm{~m}$ amsl and Page 7 of 41 
$10 \mathrm{~m}$ from the coastline, which is covered with lichens of the species Opegrapha durieui. Lichen size measurements and photographic record for lichen cover measurements were undertaken in 31-07-2016 along the limestone stones limiting the upper left side of the door (Figure S8).
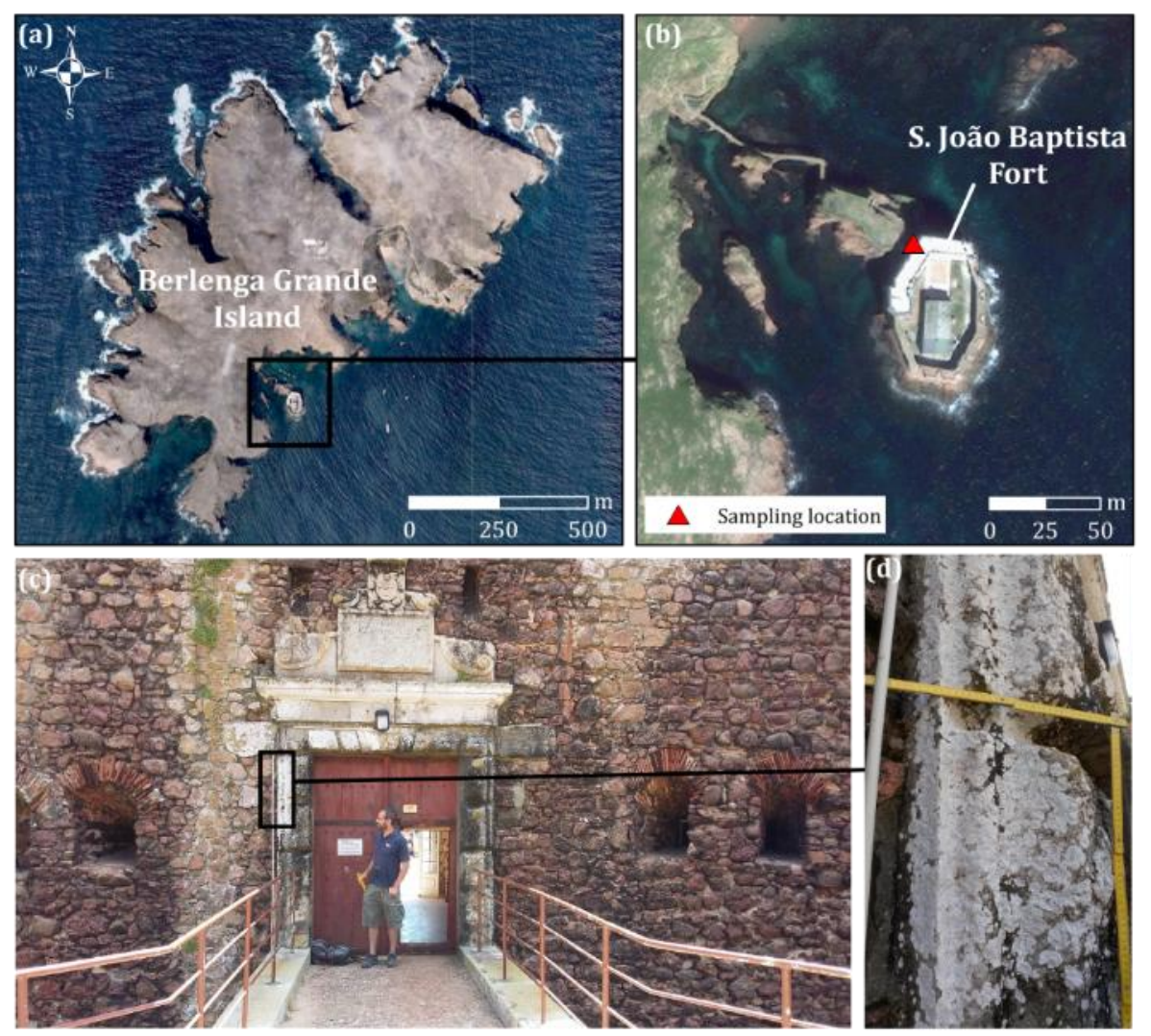

Figure S8: (a) Location of the AF04 control point in Berlenga Grande island (image source: "Berlenga Grande Islands." 455993m E and 4362855m N Universal Transverse Mercator WGS84, Google Earth, Image from October 30, 2006, Accessed on August 8, 2016). (b) Sampling location (source of the satellite image: Esri, Digital Globe, GeoEye, i-cubed, USDA, USGS, AEX, Getmapping, Aerogrid, IGN, IGP, swisstopo, and the GIS User Community. (c) Sampling location. (d) Detail of the lichens covering the surface of the door-frame. Vertical scale $0.42 \mathrm{~m}$; horizontal scale $0.19 \mathrm{~m}$.

\section{AF05 Baluarte Redondo: 1558}

The AF05 control point is in Baluarte Redondo, a small round fort located on the W coast of Portugal, corresponding to the oldest defensive structure in the dataset (Mateus, 1999). As stated in an inscription over the main door, the construction of this structure ended in 1558 (Mateus, 1999). The main door of the fort comprises clastic limestone blocks forming a vertical surface facing $12^{\circ} \mathrm{N}$ at $14 \mathrm{~m}$ amsl and $27 \mathrm{~m}$ from the coastline. Photographic record for lichen cover measurements was undertaken on 17-06-2015, on the left side of the main 
door. Lichen size was measured on 05-08-2016 (Figure S9). Baluarte Redondo fort has been subject to improvements, such as cleaning, plastering, and painting. The maintenance of this structure resulted in the death of lichens and subsequent stone discoloration. The time of exposure considered in this control point might be overestimated, given that the dates of reconstruction and cleaning are unknown. The site was re-visited in 26-01-2020 to photograph lichen thalli for direct lichen growth measurements.
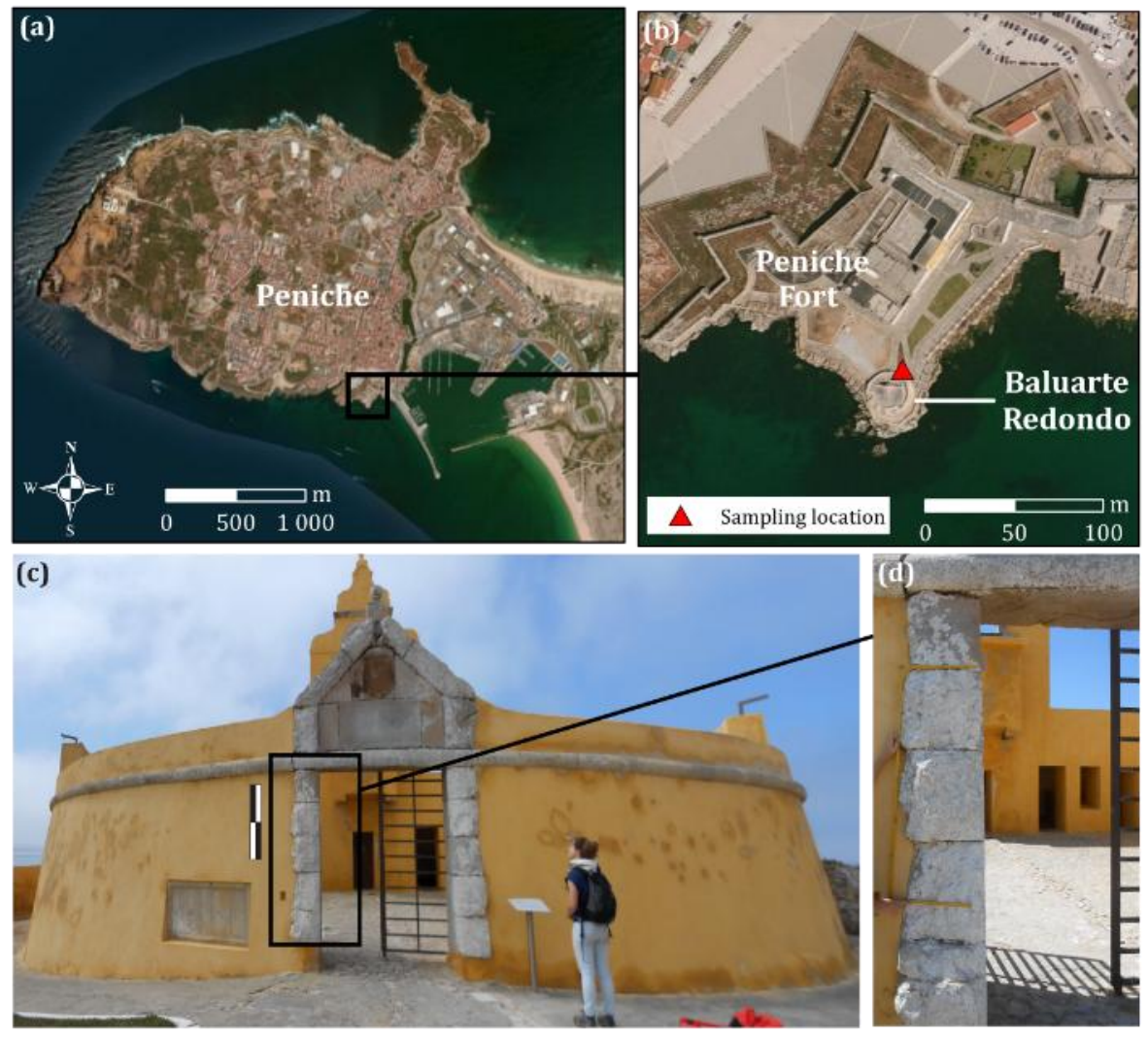

Figure S9: (a) Location of the AF05. (b) Location of Baluarte Redondo fort (Maps built with Esri@ ArcMapTM 10.4, source of the satellite images: Esri, Digital Globe, GeoEye, icubed, USDA, USGS, AEX, Getmapping, Aerogrid, IGN, IGP, swisstopo, and the GIS User Community). (c) Main door (vertical scale 1m). (d) Surface used in lichen cover measurements (vertical scale $1.2 \mathrm{~m}$, horizontal scale $0.2 \mathrm{~m}$ ).

\section{RF01: Cliffs in S. Lourenço beach: 2011-2012}

RF01 control point corresponds to a rock-fall scar in the south limiting cliffs of S. Lourenço beach ( $\mathrm{N}$ of Ericeira). A large boulder of clastic limestone was detached from the cliff-face at $14 \mathrm{~m}$ amsl and $132 \mathrm{~m}$ from the coastline (Figure S10a, c, f, and g). This movement generated a vertical surface facing North (surface aspect $335^{\circ}$ ). Based on field observations and photographic records, it was possible to time-constraint the mass movement between September 2011 and 30-05-2012. Direct observation of the control surface occurred on 20Page 9 of 41 
09-2013. No visible lichens were covering the surface exposed after the rock-fall, contrasting with older surfaces of the cliff covered with patina and presenting small lichen thalli. The site was re-visited in 19-01-2020, when new lichen thalli were photograph for direct growth measurements.

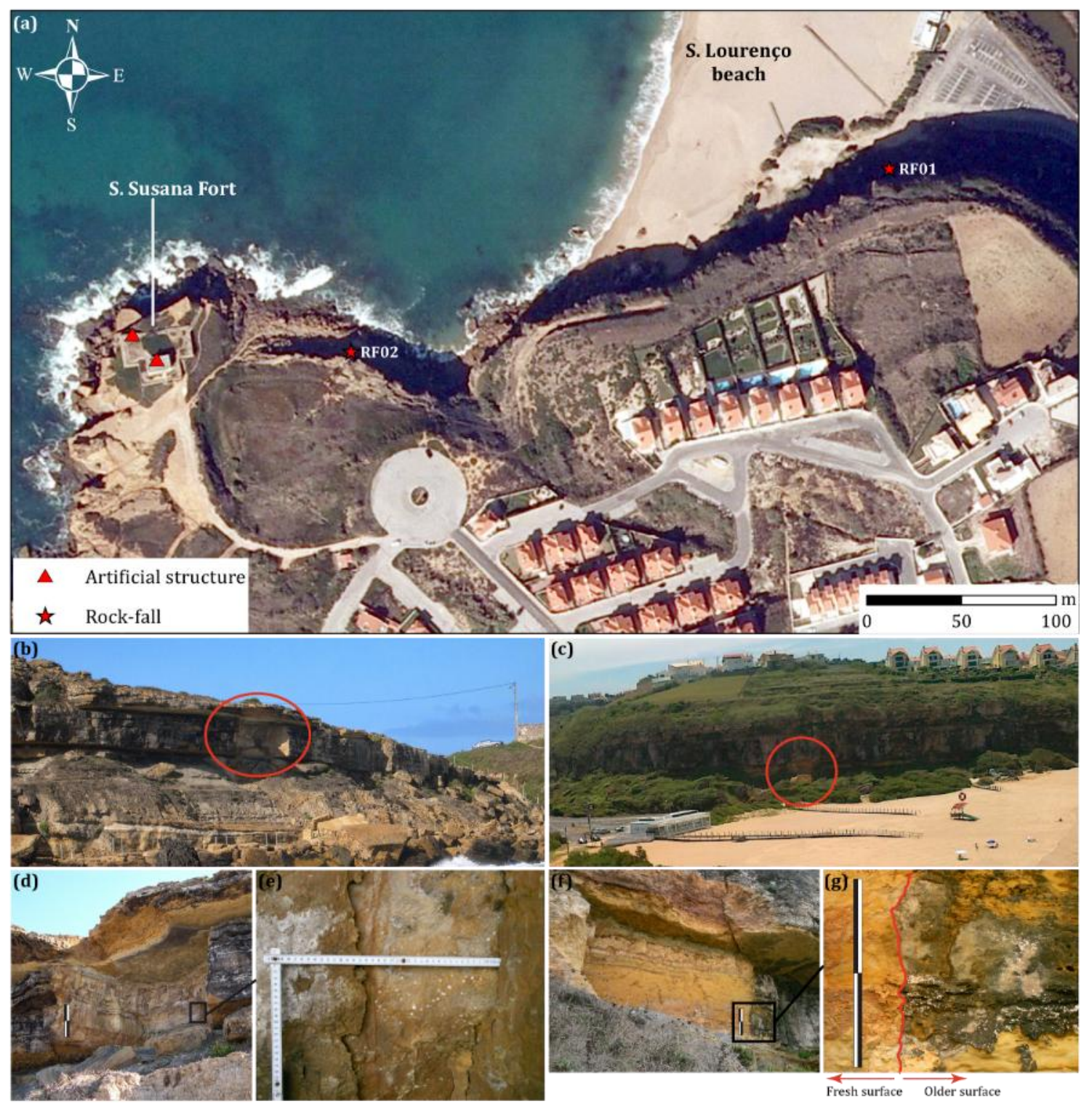

Figure S10: (a) Location of RF01 and RF02 control points over digital orthophotos

(IGEO, 2010). (b) RF02 Rock-fall scar circled in red. (c) RF01 Rock-fall scar and resulting boulder circled in red. (d) RF02 rock-fall scar (vertical scale corresponds to $1 \mathrm{~m}$ ). (e) Detail of lichen cover in RF02 (vertical scale is $0.2 \mathrm{~m}$, and the horizontal scale is $0.4 \mathrm{~m}$ ). (f) Part of RF01 surface. (g) Detail of the contrast in lichen cover between the RF01 fresh and older surfaces (vertical scale corresponds to $1 \mathrm{~m}$ ). 


\section{RF02: Cliffs in S. Lourenço beach: 2005-2006}

RF02 control point comprises a rock-fall scar located further west from RF01, still in the south limiting cliffs of S. Lourenço beach. Movement of a clastic limestone boulder was detected on photographs. Detailed observations of changes occurring in this location, made by Paulo Henriques (geologist in the Portuguese Authority for Civil Protection - Autoridade Nacional de Protecção Cívil), lead to the time constriction of the rock-fall between 1-112005 and 10-06-2006. The cliff-face fresh surface is vertical, facing $\mathrm{N}$ (surface aspect is $10^{\circ}$ ), at $9 \mathrm{~m}$ amsl, $17 \mathrm{~m}$ away from the coastline (Figure S10a-b and d-e). Lichen size sampling and photographic records were undertaken on 20-09-2013. The site was re-visited in 19-01-2020 to photograph lichen thalli for direct lichen growth measurements.

\section{AF06 Fencing wall in Santa Susana's Fort: 1657-1777}

AF06 control surface is located in the fencing wall of Santa Susana Fort (Figure S11). The fort was built in 1657 to protect the land from pirate attacks (Costa, 1997). By 1777 the Fort was reported to be missing plaster, and its condition was improved in 1831 (Costa, 1997). A part of the fort was demolished between 1944 and 1949, and a new building was built in its place (Costa, 1997). The comparison of the current architectural plant with the original, available in Costa (1997), showed that the northern wall of the fort maintained its configuration. Field observation confirmed the existence of an older and preserved section of the fencing wall missing plaster, made of pilled clastic limestone cobles (Figure S11a and b). The fencing wall forms an $\mathrm{N}$-facing (surface aspect $350^{\circ}$ ) near-vertical surface (slope of $72^{\circ}$ ). Lichen size and cover measurements were undertaken on 26-12-2013 on the pilled cobles. The site was re-visited on 26-01-2020 to photograph lichen thalli for direct growth measurements. 


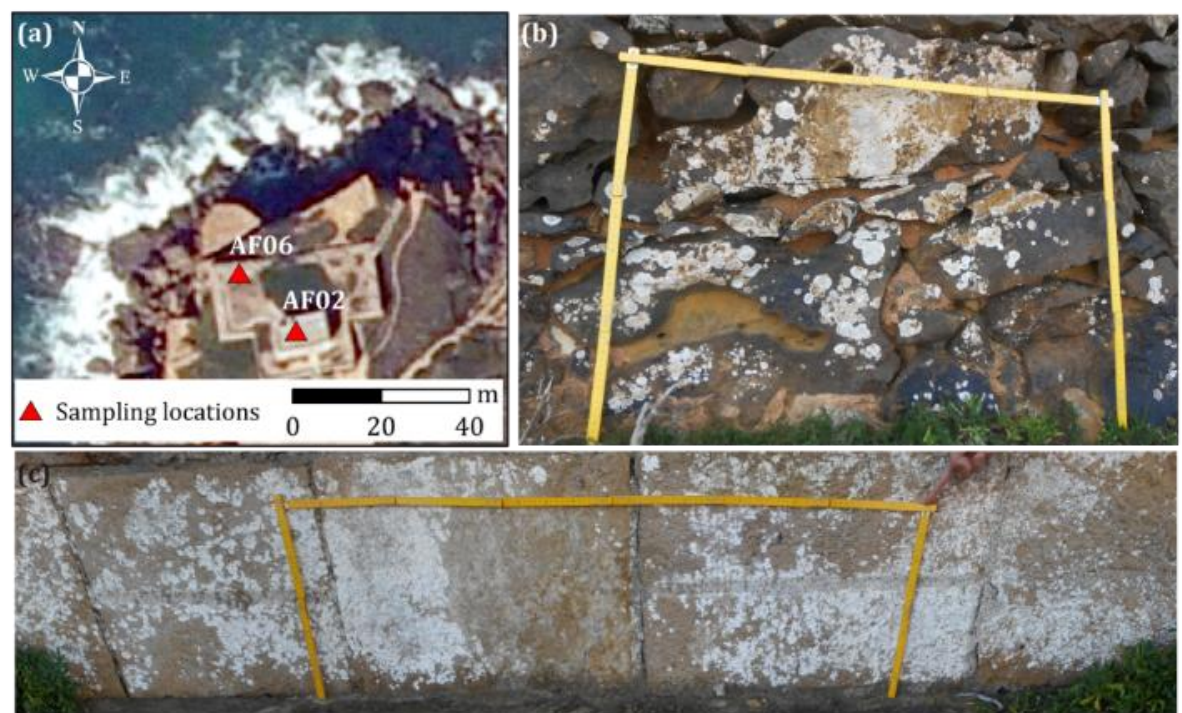

Figure S11: (a) Location of AF06 and AF02 control points in Santa Susana Fort over digital orthophotos (IGEO, 2010). (b) Detail of lichens covering surface AF06 (vertical scale corresponds to $0.6 \mathrm{~m}$ and horizontal scale to $0.8 \mathrm{~m}$ ).(c) Detail of lichens covering surface AF02 (vertical scale $0.4 \mathrm{~m}$; horizontal scale $1.2 \mathrm{~m}$ ).

\section{AF02 Santa Susana Fort: 1944-1949}

The remaining part of the Santa Susana fort is younger than the fencing wall and dated from 1944-1949 (Costa, 1997). The $\mathrm{N}$-facing (surface aspect $350^{\circ}$ ) vertical wall of the fort, located at 18m amsl and30 $\mathrm{m}$ away from the coastline, comprises clastic limestone blocks (Figure S11c). Lichen size measurements and photographic record for cover measurements were undertaken over these blocks on 26-12-2013. The site was re-visited on 19-01-2020 to photograph lichen thalli for direct growth measurements.

\section{RF03 Cliffs in Ribeira de Ilhas beach: 1980-1989}

RF03 control surface is a massive clastic limestone rock-fall scar facing north (surface aspect $352^{\circ}$ ) in the cliffs limiting Ribeira de Ilhas beach (Figure S12). The surface is located at $37 \mathrm{~m}$ amsl and $55 \mathrm{~m}$ away from the coastline. The rock-fall movement was detected by comparing aerial photographs from 1980 and 1989 (Figure S12b and c). Lichen size measurements and photographic record for lichen cover measurements on this surface were undertaken on 07-11-2013. 


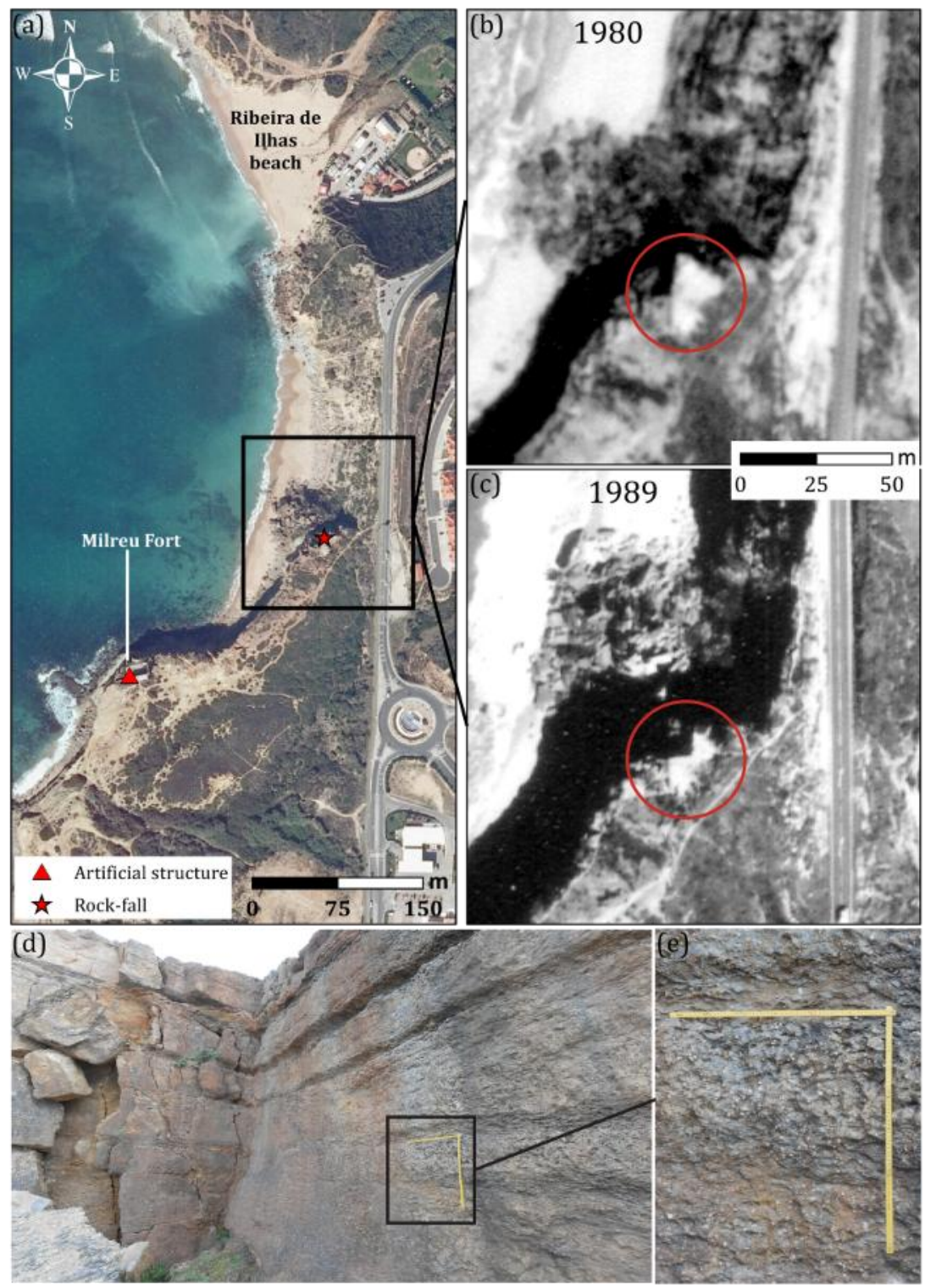

Figure S12: (a) Location of RF03 rock-fall scar and Milreu Fort (AF07 control point) over digital orthophotos (IGEO, 2010). (b) Aerial photograph from 24-05-1980 with a red circle limiting the general area of the RF03 rock-fall. (c) Aerial photograph from 18-041989 with a red circle limiting the general area of the rock-fall. (d) RF03 surface. (e) Lichens covering surface RF03 (vertical and horizontal scales $0.6 \mathrm{~m}$ ).

\section{AF07 Milreu Fort: 1657-1777}

Control point AF07 is in Milreu Fort, located over a cliff edge at $21 \mathrm{~m}$ amsl and 34m away from the coastline (Figure S13). The fort was built to protect the land from piracy attacks (Costa, 1997). The most likely age of this fort is 1657 (Costa, 1997). This fort was reported to be missing plaster in 1777, and reconstruction occurred in 1831 (Costa, 1997). Differences in building materials used during reconstruction are easily detected: plaster was 
replaced by concrete, and patched walls were made of bricks instead of limestone quarry (Figure S13b).

Lichen size was measured on 30-01-2014 over unplastered clastic limestone cobbles that comprise the $\mathrm{N}$ and E-facing walls, which have become exposed sometime between 1657 (date of construction) and 1777. Photographic record for lichen cover measurements was undertaken on 07-11-2013, at the base of the N-facing wall over building blocks, likely exposed since 1957 (Figure S13b and c).
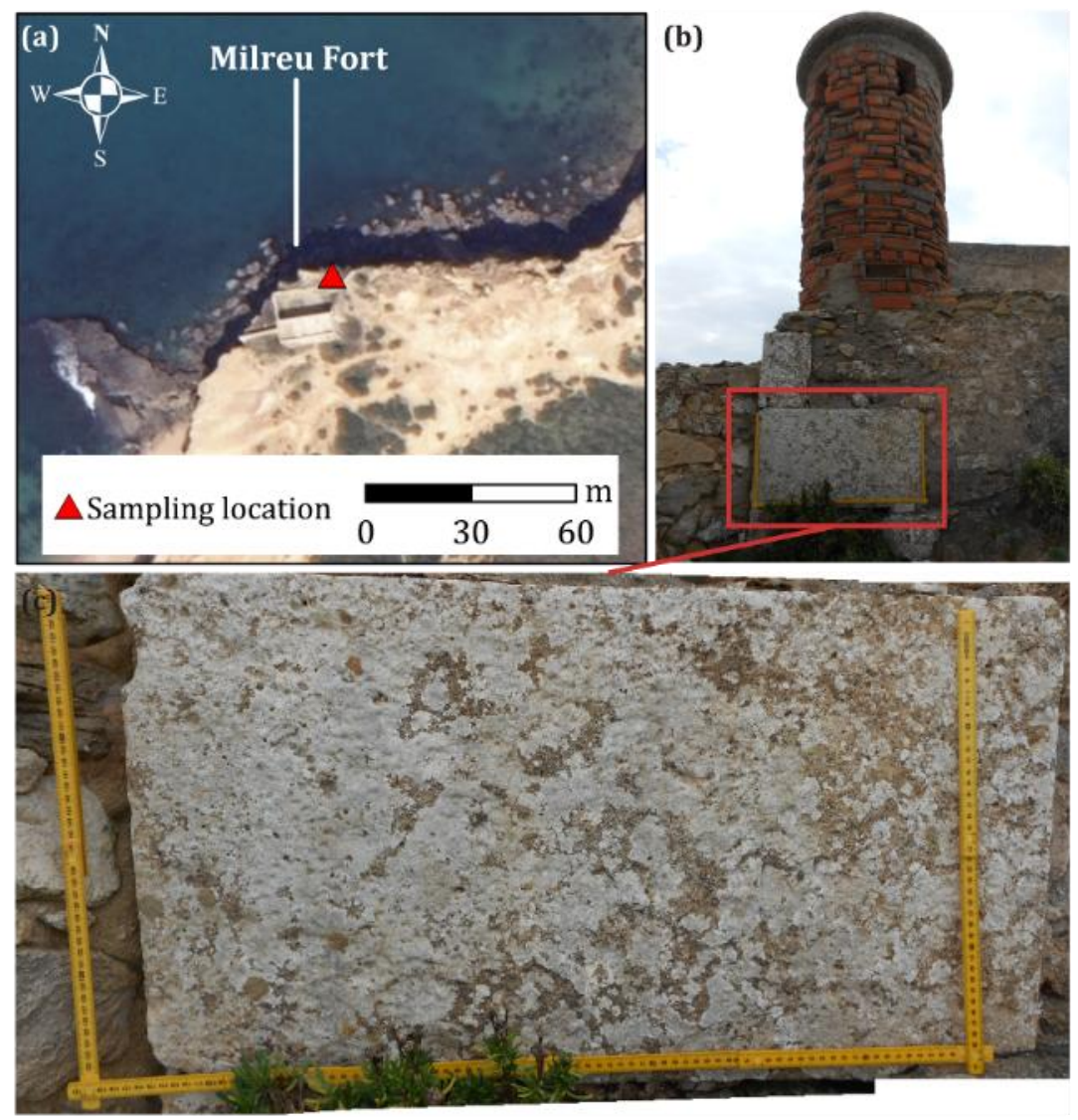

Figure S13: (a) Location of the AF07 control point over digital orthophotos (IGEO, 2010). (b) Cornerstone used in lichen cover measurements (vertical scale $0.2 \mathrm{~m}$; horizontal scale $0.8 \mathrm{~m}$ ). (c) Lichens covering the surface of the cornerstone (vertical scale $0.2 \mathrm{~m}$; horizontal scale $0.8 \mathrm{~m})$.

\section{AF01 Concrete wall in Ericeira: 1980-2000}

AF01 control point corresponds to an artificial wall at $20 \mathrm{~m}$ amsl and $20 \mathrm{~m}$ away from the coastline, re-built between 1980 and 2000 (Figure S14). Changes in the configuration of the wall were detected by comparing aerial photographs. Lichen size measurements and 
photographic record for lichen cover measurements were undertaken on 18-02-2014, over the $\mathrm{N}$-facing section of the wall (surface aspect $6^{\circ}$ ), made of concrete (Figure S15 c and d).
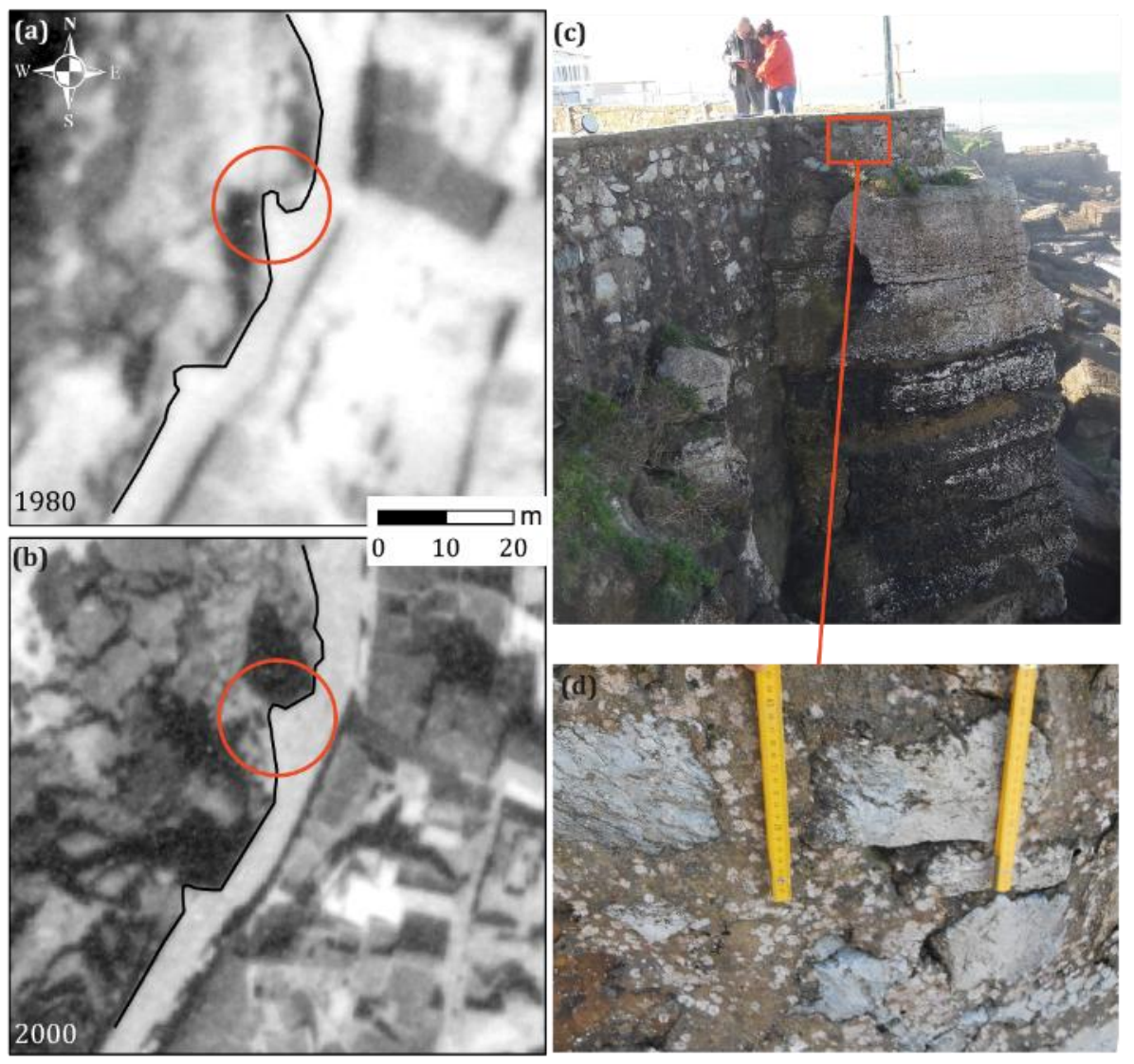

Figure S14: (a) Location of AF01 control point over an aerial photograph from 24-051980; red circle is limiting the general area of the artificial wall, here represented by the black line. (b) Aerial photograph from 24-02-2000. (c) AF01 control surface. (d) Lichens covering the surface (vertical scales $0.2 \mathrm{~m}$ ).

\section{AF08 Pessegueiro Fort: 1588-1690}

The construction of Pessegueiro Fort, where AF08 control point is located (Figure S15), began in 1588 (Quaresma, 2007). The construction was repeatedly interrupted and resumed under the direction of several engineers, was abandoned in 1608 (Quaresma, 2007; Guedes, 1989), and finally completed in 1690 (Quaresma, 2007; Severino, 2014). Sampling was focused on walls of the fort's trench made of aeolianite blocks. Lichen size measurements were undertaken in the NW and SW walls of the trench, facing the fort (surface aspect ranging from $20^{\circ}$ to $130^{\circ}$ ), on 03-08-2016. Photographic record for lichen cover measurements was undertaken in the walls of the fort's SW trench, facing NE. 

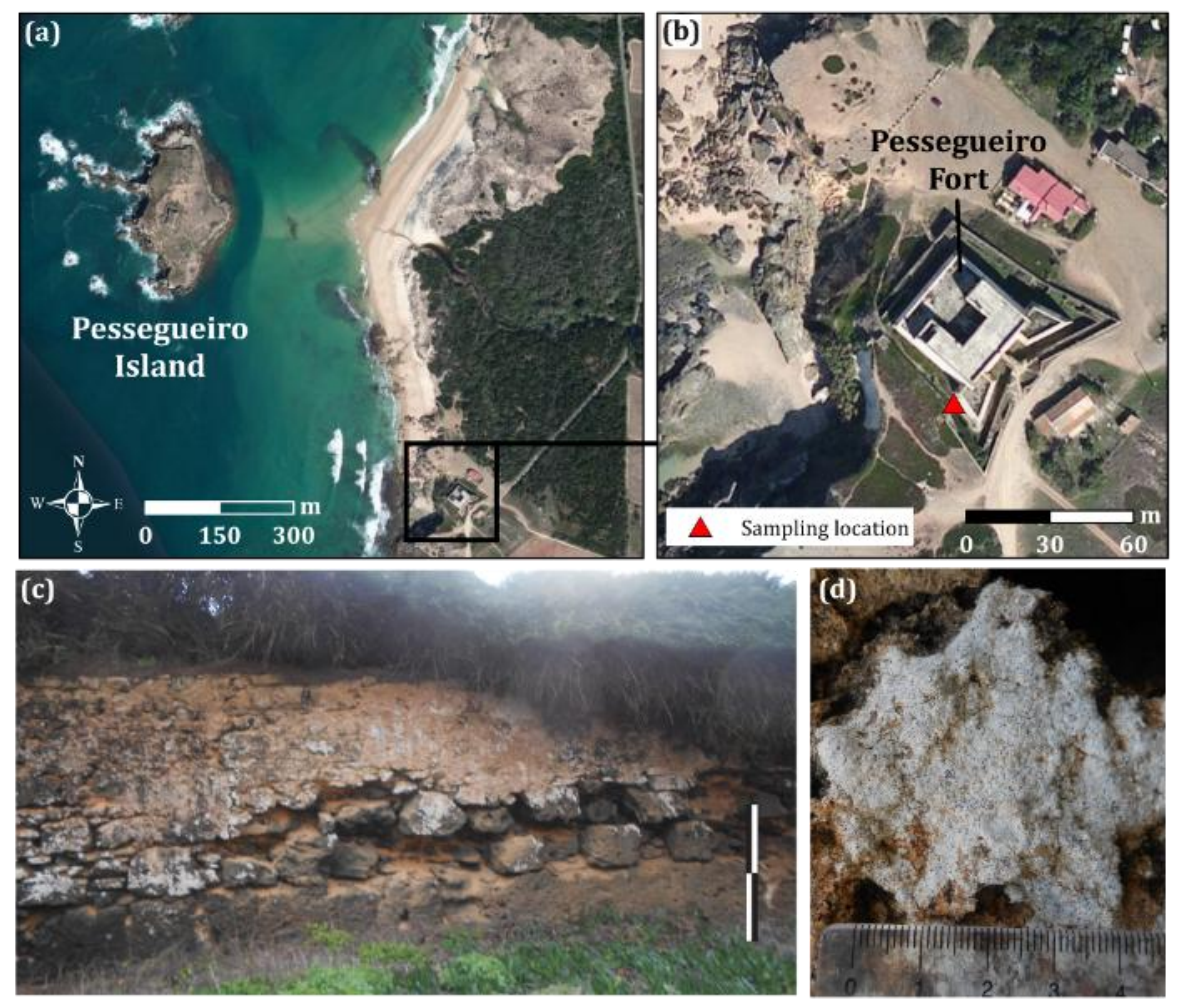

Figure S15: (a) AF08 control point. (a) Location of the control point in Pessegueiro Fort.

(b) Lichen size and cover sampling location (Maps built with Esri@ ArcMapTM 10.4, source of the satellite images: Esri, Digital Globe, GeoEye, i-cubed, USDA, USGS, AEX, Getmapping, Aerogrid, IGN, IGP, swisstopo, and the GIS User Community). (c) Wall of the southern trench used in lichen cover measurements (vertical scale $1 \mathrm{~m}$ ). (d) Detail of a lichen in the trench wall.

\section{AF09 Belixe Fortress: 1632}

AF09 control point is located on Belixe Fort, in the SW tip of mainland Portugal (Figure S16a). This structure was built during the XV-XVI centuries, to be destroyed by pirate Francis Drake in 1587, and later rebuilt in 1632 (Severino, 2014; Direção Geral dos Edifícios e Monumentos Nacionais, 1960). The 1755 earthquake caused some damages to the fort, later to be reconstructed by Direção Geral dos Edifícios e Monumentos Nacionais (General Directorate of National Buildings and Monuments) between 1940 and 1960 (Direção Geral dos Edifícios e Monumentos Nacionais, 1960). Photographs taken before and after the reconstruction show an unharmed and untouched bulwark, in the lower eastern section of the fortress. Photographic record for lichen cover measurements was undertaken on 26-01-2014 and lichen size measurements on 3-08-2016. Both variables were sampled over pilled shelly limestone cobles on the vertical $\mathrm{N}$-facing wall of the fort (surface aspect $354^{\circ}$ ), at $52 \mathrm{~m}$ amsl, and $70 \mathrm{~m}$ away from the coastline (Figure S16b-d). 


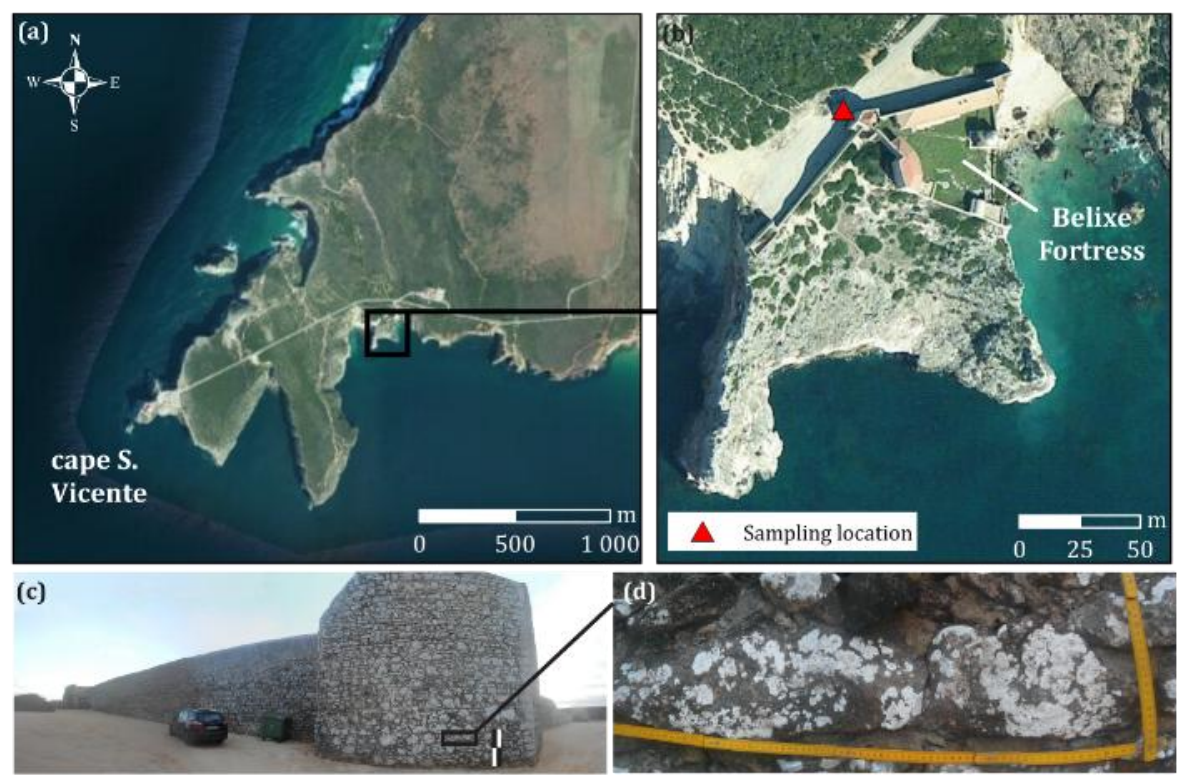

Figure S16: (a) Location of the control point AF09 Belixe Fortress. (b) Sampling location (Maps built with Esri@ ArcMapTM 10.4, source of the satellite images: Esri, Digital

Globe, GeoEye, i-cubed, USDA, USGS, AEX, Getmapping, Aerogrid, IGN, IGP, swisstopo, and the GIS User Community). (c) Eastern part of Belixe Fortress bulwark (vertical scale $1 \mathrm{~m}$ ). (d) Area of the bulwark used in lichen cover measurements (vertical scale $0.2 \mathrm{~m}$ and horizontal scale $0.8 \mathrm{~m}$ ).

\section{AF10 Sagres Fortress: 1793}

AF10 is in Sagres Fortress, in the SW tip of mainland Portugal (Figure S17a). This structure is dated from the XV century, evidenced by archaeological remains (Silva, 2013) and by extensive historical documents that mention the existence of a village attributed to this location (Direção Geral dos Edifícios e Monumentos Nacionais, 1960). However, the current configuration of the bulwark is different from the portrayed in historical documents (Direção Geral dos Edifícios e Monumentos Nacionais, 1960; Mesquita, 2000). The original bulwark and gateway were destroyed by pirate Francis Drake in 1587 and by two earthquakes (27-12-1722 and 1-11-1755) (Direção Geral dos Edifícios e Monumentos Nacionais, 1960; Mesquita, 2000; Silva, 2013). Reconstruction with the current configuration finished in 1793, as stated in an inscription in the coat of arms (Direção Geral dos Edifícios e Monumentos Nacionais, 1960; Mesquita, 2000; Silva, 2013). Since then, improvement works were carried out by Direção Geral dos Edifícios e Monumentos Nacionais, including the extension of the gateway, during 1940-1960 (Direção Geral dos Edifícios e Monumentos Nacionais, 1960; Mesquita, 2000). The crystalline limestone quarry that composes thw gateway was removed during reconstruction and later re-used, 
maintaining at least part of the lichen cover, shown in photographs taken immediately after improvement works, available in Direção Geral dos Edifícios e Monumentos Nacionais (1960).

Photographic record for measurement of lichen cover was undertaken on 26-01-2014, over a vertical surface facing NE (surface aspect $50^{\circ}$ ) at $37 \mathrm{~m}$ amsl and $102 \mathrm{~m}$ away from the coastline, over the limestone quarry surrounding the main entrance of the fort (Figure S17bd). Initial observations indicated that many thalli were dead, possibly due to stone cleaning during reconstruction. The absence of lichens and the presence of stone discoloration in other limestone blocks throughout the fort wall strongly supports this interpretation. Lichen size and cover were measured in limestone stones with preserved thalli, located on the right side of the gateway of Sagres Fortress. Species identification was only possible for two of the five largest thalli measured in this location, given the absence of preserved reproductive structures. Lichen size measurements were undertaken on 03-08-2016. An underestimation of percentage cover is expected due to lichen removal during stone cleaning. Also, given that most individuals were dead, possibly due to reconstruction during 1940-1960, it was assumed that lichens stopped growing in 1950.

\section{AF11 S. Luís Almádena Fort: 1632}

AF11 control point, in S. Luís de Almádena Fort, is on the S-facing coast of Portugal (Figure $\mathrm{S} 18 \mathrm{a})$. The fort is in ruins, although it is possible to identify most of the original architecture (Severino, 2014). The fort was built in 1632 to defend the coastline, particularly the fishing settlements frequently attacked by pirates (Coutinho, 1997). Photographic record for lichen cover measurements were undertaken on 26-01-2014 over unplastered clastic limestone cobbles comprising the $\mathrm{N}$-facing (surface aspect $328^{\circ}$ ) walls of the fort, at $69 \mathrm{~m}$ amsl and $97 \mathrm{~m}$ from the coastline (Figure S19b and c). Sampling for lichen size was undertaken in the same wall on 03-08-2016. 

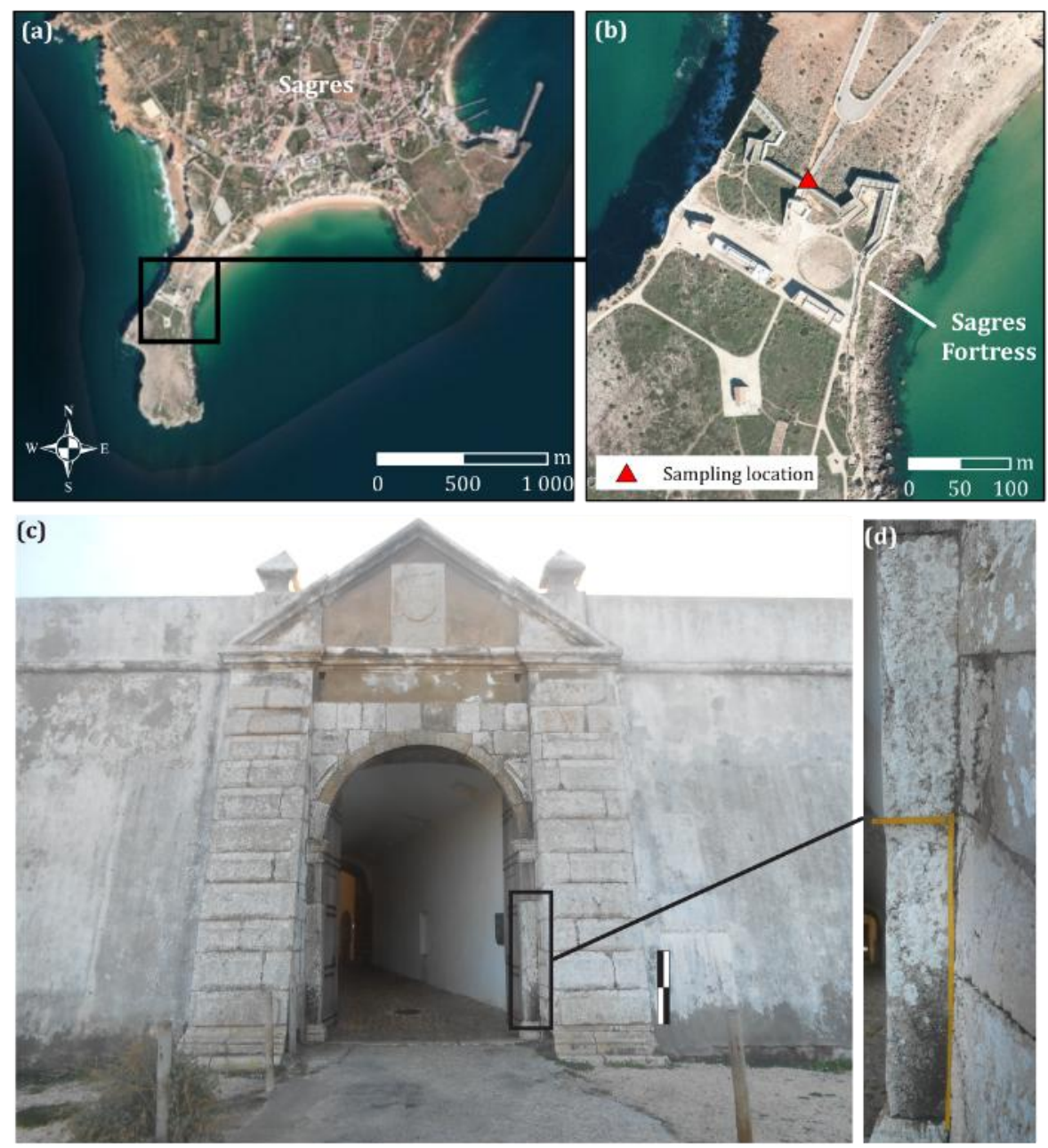

Figure S17: (a) Location of Sagres Fortress. (b) Sampling location in Sagres Fortress (Maps built with Esri@ ArcMapTM 10.4, source of the satellite images: Esri, Digital

Globe, GeoEye, i-cubed, USDA, USGS, AEX, Getmapping, Aerogrid, IGN, IGP, swisstopo, and the GIS User Community). (c) Photo of the gateway (vertical scale $1 \mathrm{~m}$ ). (d) Area selected for measurements of lichen cover (vertical scale $1 \mathrm{~m}$ and horizontal scale $0.2 \mathrm{~m})$. 

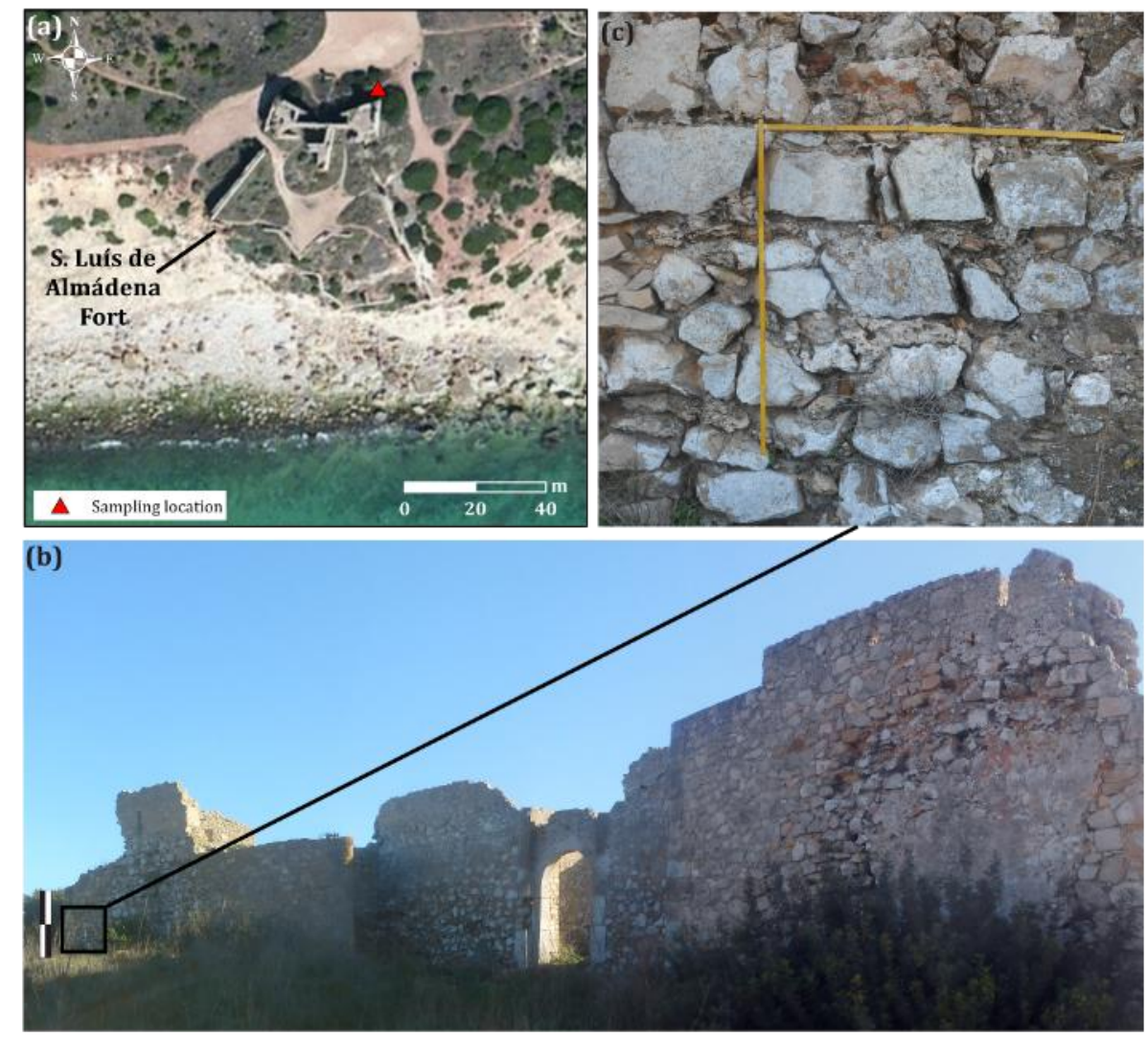

Figure S18: (a) Location of AF11 control point in S. Luís de Almádena Fort (Maps built with Esri@ ArcMapTM 10.4, source of the satellite images: Esri, Digital Globe, GeoEye, i-cubed, USDA, USGS, AEX, Getmapping, Aerogrid, IGN, IGP, swisstopo, and the GIS User Community). (b) View of the northern wall of the Fort (vertical scale $2 \mathrm{~m}$ ). (c) Detail of the wall surface used in lichen cover measurements (vertical and horizontal scales $1 \mathrm{~m}$ ).

\section{Summary}

The information regarding control points is summarized in Table S2. Lichen coalescence was frequently observed in surfaces with a long time of exposure, making the identification and measurement of individual lichens a complicated task. This was the case in control points AF11, AF08, AF07, and AF05. Furthermore, in some forts, lichens were found and measured over unplastered limestones, such as AF06, AF07, AF11, and AF08. Unplastering resulted from deterioration of plaster applied originally over the construction material. In these cases, it was considered that exposure occurred immediately after construction, except for AF07 and AF06 sampling locations, where 18th-century historical documents on the state of preservation of the forts aided to constrain the age of exposure of stones (Costa, 1997). The age of exposure can be overestimated in these cases. 
In AF10 and AF05 sampling locations, the limestone blocks comprising the doorframes have been partially cleaned; this is evidenced by the large number of dead organisms and stone discoloration. In both locations, the date of the most recent cleaning operation is unknown. In the case of the AF10 control point, lichens were assumed to have stopped growing following major reconstruction undertaken around 1950 (between 1940 and 1960). Maintenance of AF05 repeatedly occurred due to the continuous use of that defensive structure, precluding the establishment of the most recent date of stone cleaning. 
Table S2: Control points used in the construction of the lichen growth curve for the species Opegrapha durieui. RF stands for rock-fall and AF for artificial structure. *Time of exposure ended before date of measurement due to stone cleaning during reconstruction. DDdecimal degrees; amsl-above mean sea level

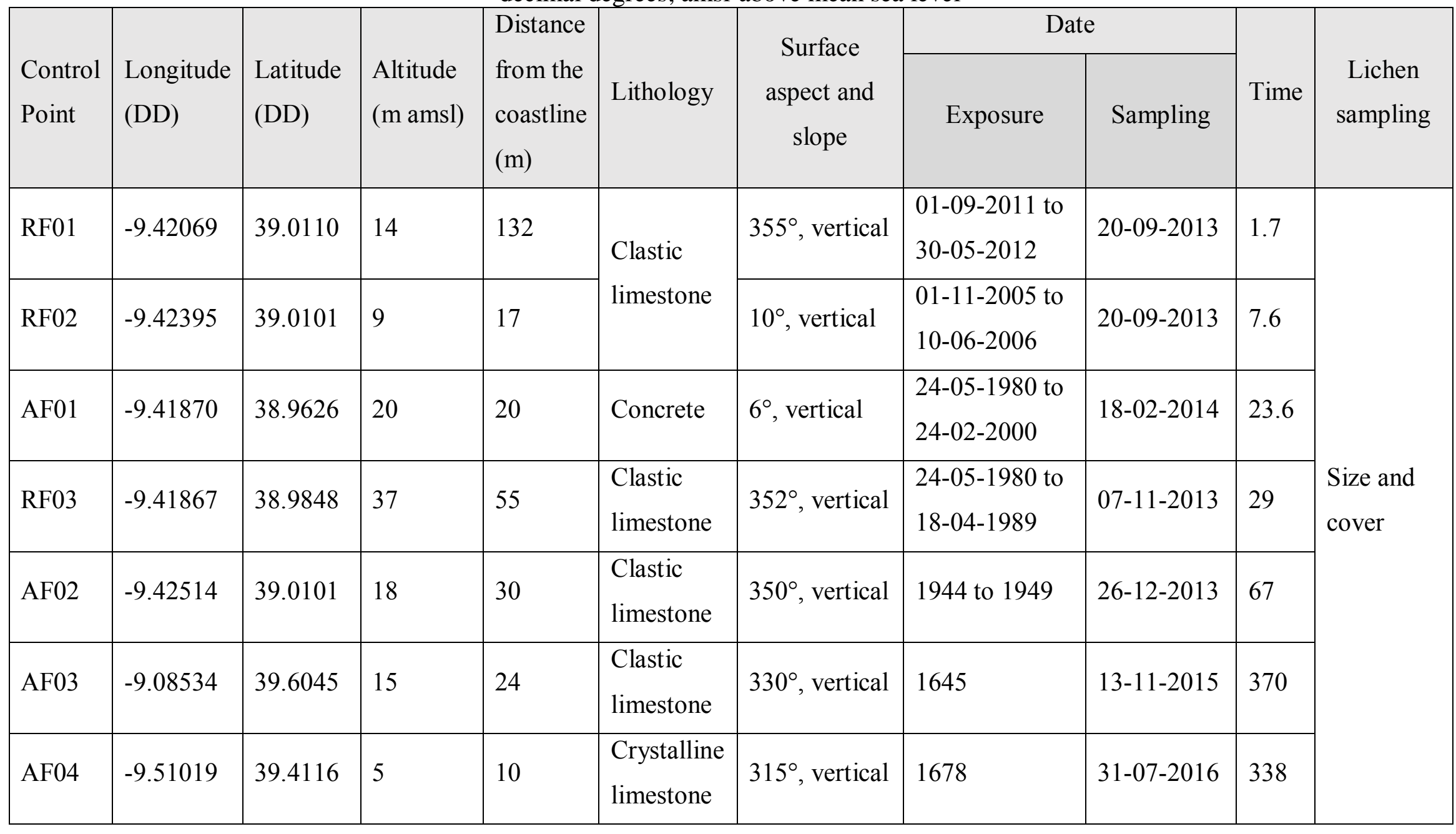




\begin{tabular}{|c|c|c|c|c|c|c|c|c|c|c|}
\hline \multirow{2}{*}{$\begin{array}{l}\text { Control } \\
\text { Point }\end{array}$} & \multirow{2}{*}{$\begin{array}{l}\text { Longitude } \\
\text { (DD) }\end{array}$} & \multirow{2}{*}{$\begin{array}{l}\text { Latitude } \\
\text { (DD) }\end{array}$} & \multirow{2}{*}{$\begin{array}{l}\text { Altitude } \\
\text { (m amsl) }\end{array}$} & \multirow{2}{*}{$\begin{array}{l}\text { Distance } \\
\text { from the } \\
\text { coastline } \\
\text { (m) }\end{array}$} & \multirow{2}{*}{ Lithology } & \multirow{2}{*}{$\begin{array}{c}\text { Surface } \\
\text { aspect and } \\
\text { slope }\end{array}$} & \multicolumn{2}{|c|}{ Date } & \multirow{2}{*}{ Time } & \multirow{2}{*}{$\begin{array}{c}\text { Lichen } \\
\text { sampling }\end{array}$} \\
\hline & & & & & & & Exposure & Sampling & & \\
\hline \multirow{2}{*}{ AF05 } & \multirow{2}{*}{-9.38124} & \multirow{2}{*}{39.3527} & \multirow{2}{*}{14} & \multirow{2}{*}{27} & \multirow{2}{*}{$\begin{array}{l}\text { Clastic } \\
\text { limestone }\end{array}$} & \multirow{2}{*}{$12^{\circ}$, vertical } & \multirow{2}{*}{1558} & $17-06-2015$ & 457 & Cover \\
\hline & & & & & & & & 05-08-2016 & 458 & Size \\
\hline AF06 & -9.42529 & 39.0102 & 17 & 19 & $\begin{array}{l}\text { Clastic } \\
\text { limestone }\end{array}$ & $350^{\circ}, 72^{\circ}$ & 1657 to 1777 & $26-12-2013$ & 296 & $\begin{array}{l}\text { Size and } \\
\text { cover }\end{array}$ \\
\hline \multirow{2}{*}{ AF07 } & \multirow{2}{*}{-9.42046} & \multirow{2}{*}{38.9838} & \multirow{2}{*}{21} & \multirow{2}{*}{34} & \multirow{2}{*}{$\begin{array}{l}\text { Clastic } \\
\text { limestone }\end{array}$} & \multirow{2}{*}{ Variable } & 1657 to 1777 & $30-01-2014$ & 297 & Size \\
\hline & & & & & & & 1657 & 07-11-2013 & 356 & Cover \\
\hline \multirow{2}{*}{ AF08 } & \multirow{2}{*}{-8.79105} & \multirow{2}{*}{37.8281} & \multirow{2}{*}{13} & \multirow{2}{*}{51} & \multirow{2}{*}{ Aeolianite } & \multirow{2}{*}{ Variable } & \multirow{2}{*}{1690} & 09-02-2014 & 324 & Cover \\
\hline & & & & & & & & 03-08-2016 & 326 & Size \\
\hline \multirow{2}{*}{ AF09 } & \multirow{2}{*}{-8.98254} & \multirow{2}{*}{37.0274} & $=0$ & 70 & Shelly & $25-10-1$ & 100 & 26-01-2014 & 382 & Cover \\
\hline & & & 52 & 10 & limestone & 304 , vertical & 1032 & 03-08-2016 & 384 & Size \\
\hline $\mathrm{AF} 10$ & -894814 & 370009 & 37 & 102 & Crystalline & $50^{\circ}$ vertical & $1973 *$ & 26-01-2014 & 157 & Cover \\
\hline AГ & -0.94014 & & 31 & 102 & limestone & & & 03-08-2016 & & Size \\
\hline$\Delta \mathrm{F} 1 \mathrm{~A}$ & 880420 & 370668 & 60 & 07 & Clastic & 3280 vertical & 1632 & 26-01-2014 & 382 & Cover \\
\hline АГ 11 & $-0.004 \angle 9$ & 31.0000 & 09 & 91 & limestone & 520, vertical & 1052 & 03-08-2016 & 384 & Size \\
\hline
\end{tabular}




\section{Changes in lichen cover area, percentages and standard deviation with control area increments}
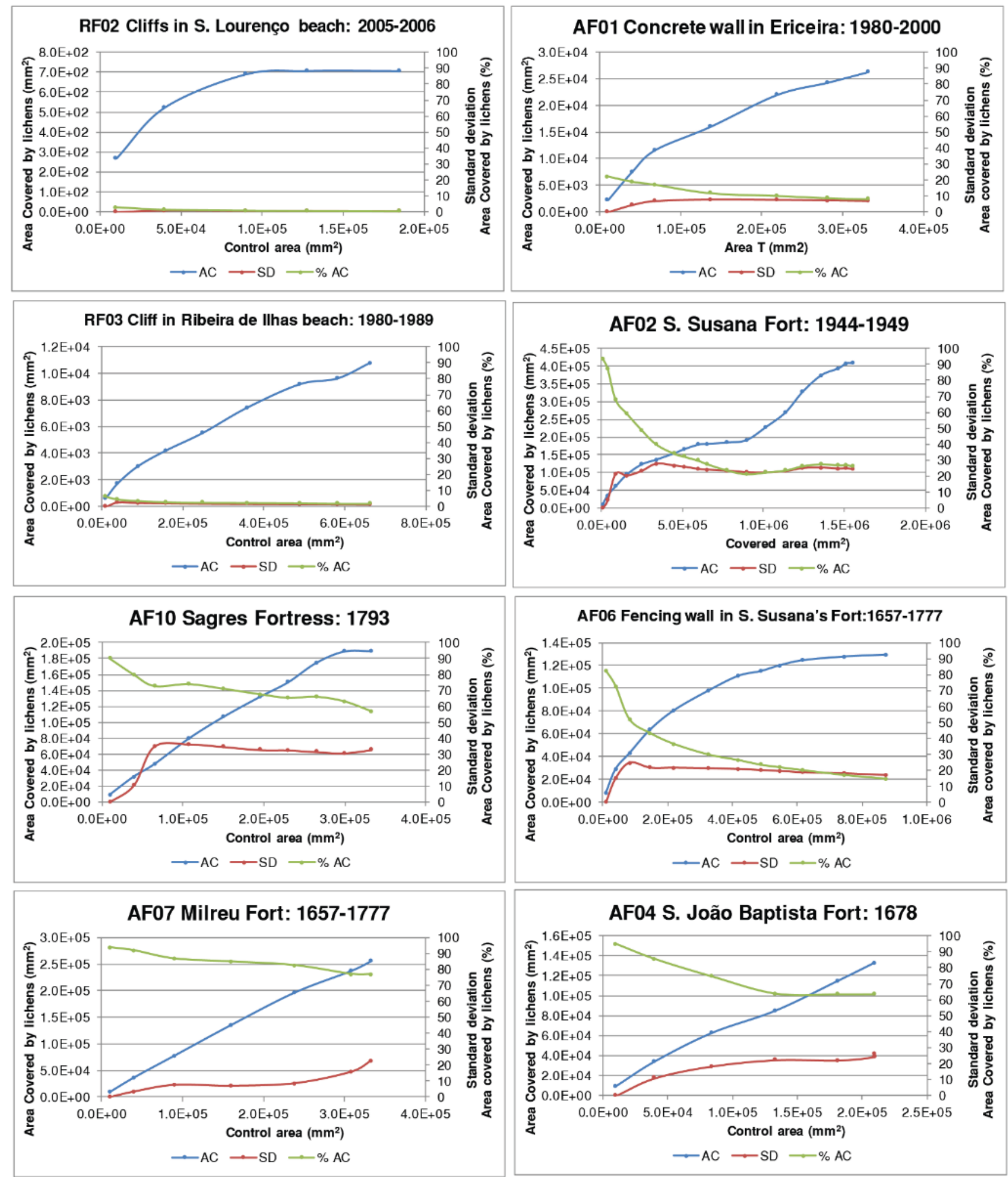

Figure S19: Plots showing changes in area covered by lichens, percentage of area covered and standard deviation, with increments in the control area 

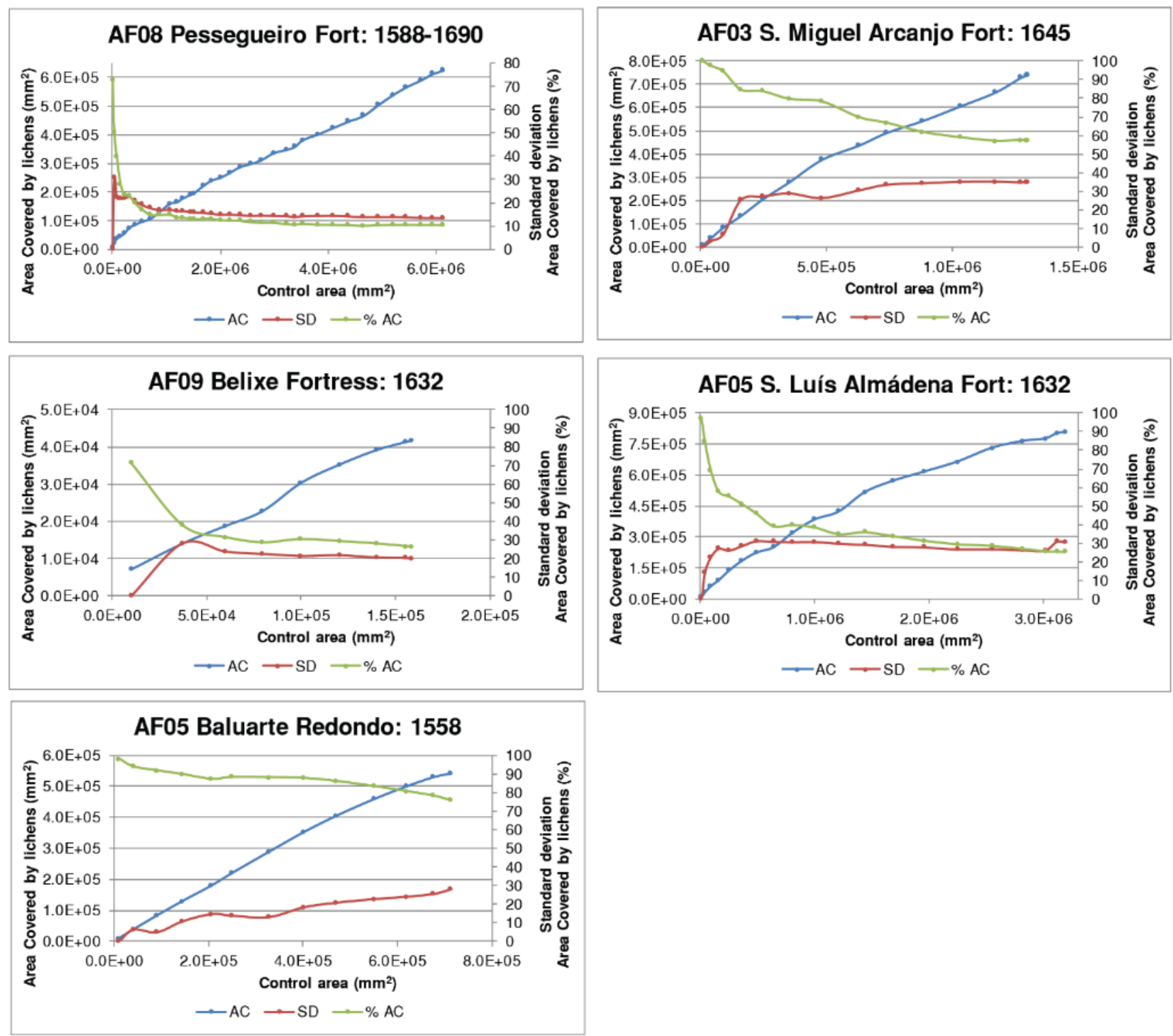

Figure S19: (cont.) Plots showing changes in area covered by lichens, percentage of area covered and standard deviation with increments in the control area 
Table S3: Bioclimatic variables, averaged for the years 1970-2000, in each control point, extracted from the WorldClim Version2 climate dataset (Fick and Hijmans, 2017).

\begin{tabular}{|l|l|l|l|l|}
\hline $\begin{array}{l}\text { Control } \\
\text { Point }\end{array}$ & $\begin{array}{l}\text { Temperature } \\
\left({ }^{\circ} \mathrm{C}\right)\end{array}$ & $\begin{array}{l}\text { Water vapor } \\
\text { pressure } \\
(\mathrm{kPa})\end{array}$ & $\begin{array}{l}\text { Solar } \\
\text { radiation } \\
\left(\mathrm{kJ} \mathrm{m}^{-2} \mathrm{day}^{-1}\right)\end{array}$ & $\begin{array}{l}\text { Precipitation } \\
(\mathrm{mm})\end{array}$ \\
\hline RF01 & 15.43 & 1.44 & 16098 & 53.50 \\
\hline RF02 & 15.43 & 1.44 & 16098 & 53.50 \\
\hline AF01 & 15.28 & 1.43 & 16188 & 55.08 \\
\hline RF03 & 15.46 & 1.43 & 16223 & 53.00 \\
\hline AF02 & 15.43 & 1.44 & 16098 & 53.50 \\
\hline AF03 & 15.12 & 1.41 & 15802 & 56.92 \\
\hline AF04 & 15.49 & 1.42 & 15718 & 52.58 \\
\hline AF05 & 15.43 & 1.43 & 15734 & 50.42 \\
\hline AF06 & 15.43 & 1.44 & 16098 & 53.50 \\
\hline AF07 & 15.46 & 1.43 & 16223 & 53.00 \\
\hline AF08 & 16.09 & 1.45 & 17183 & 46.50 \\
\hline AF09 & 16.23 & 1.47 & 17440 & 40.67 \\
\hline AF10 & 16.63 & 1.49 & 17500 & 39.58 \\
\hline AF11 & 16.78 & 1.46 & 17459 & 41.42 \\
\hline
\end{tabular}
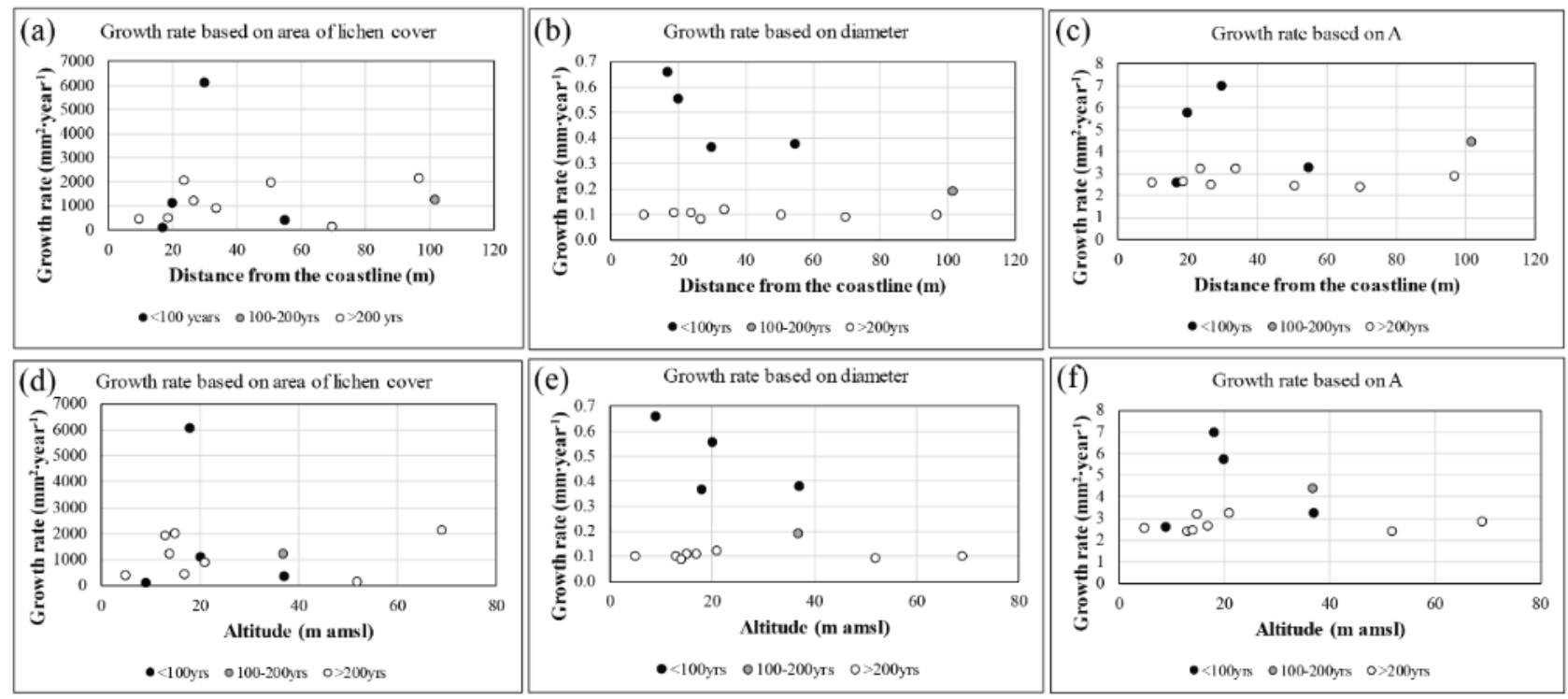

Figure S20: Scatter plots relating distance from the coastline (a-c) and altitude (d-f) with growth rate obtained from different lichen size parameters (lichen cover over a 100×100 mm control area, lichen diameter and area of the largest inscribed circle, respectively). 

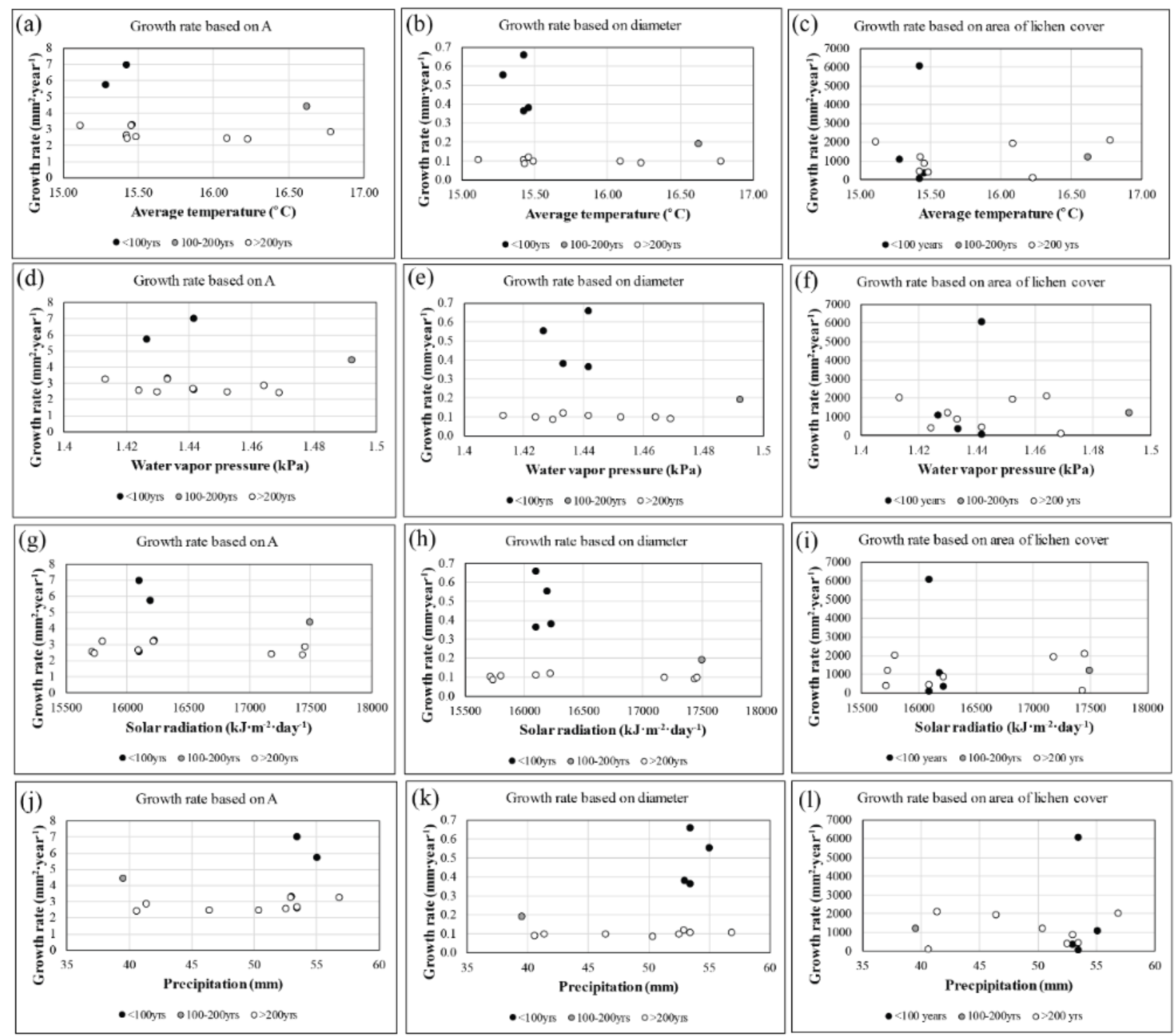

Figure S21: Scatter plots relating average temperature (a-c), water vapor pressure (d-f), solar radiation (g-i) and precipitation $(\mathrm{j}-1)$ with growth rate, obtained from different lichen size parameters (lichen cover over a $100 \times 100 \mathrm{~mm}$ control area, lichen diameter and area of the largest inscribed circle, respectively). 


\section{Direct measurements of lichen growth}

\section{RF01: Cliffs in S. Lourenço beach: 2011-2012}

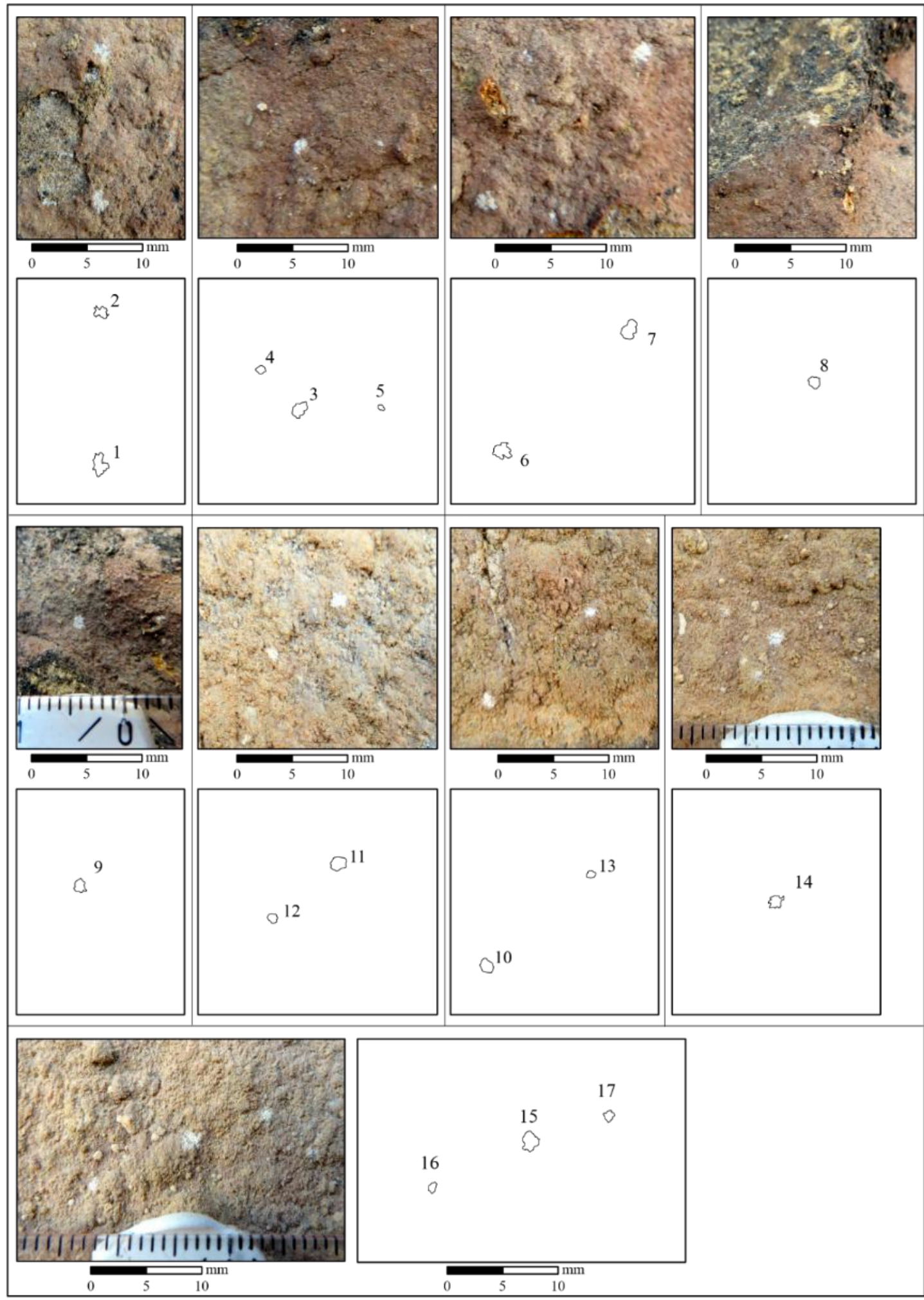

Figure S22: Photographs of lichens found in RF01 control point in 2020 and outline of lichen thalli. 
RF02: Cliffs in S. Lourenço beach: 2005-2006
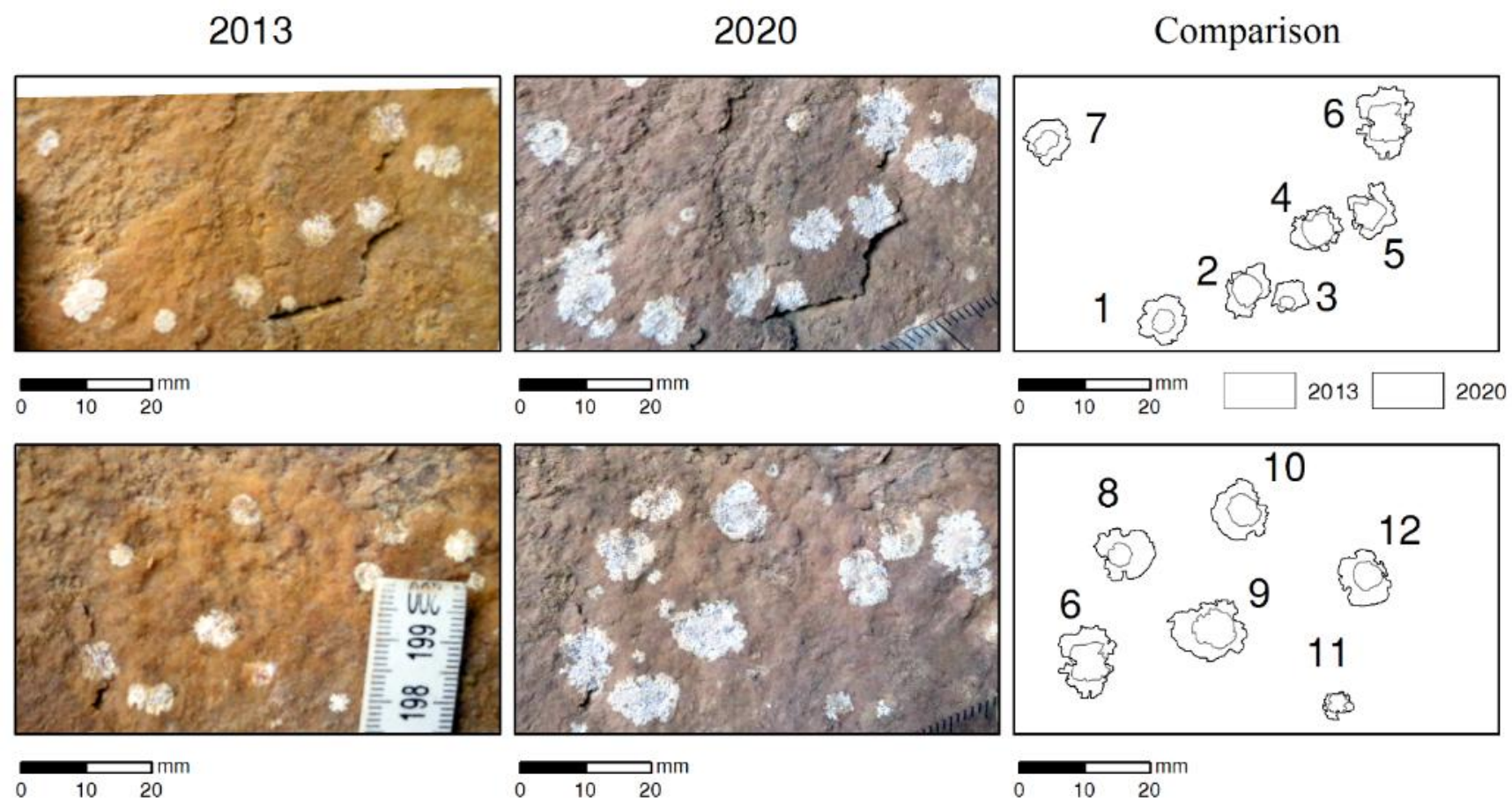

Figure S23: Photographs of lichens used for direct measurement of growth in 2013 and 2020 in RF02 control surface and comparison between the outline of lichen thalli. 

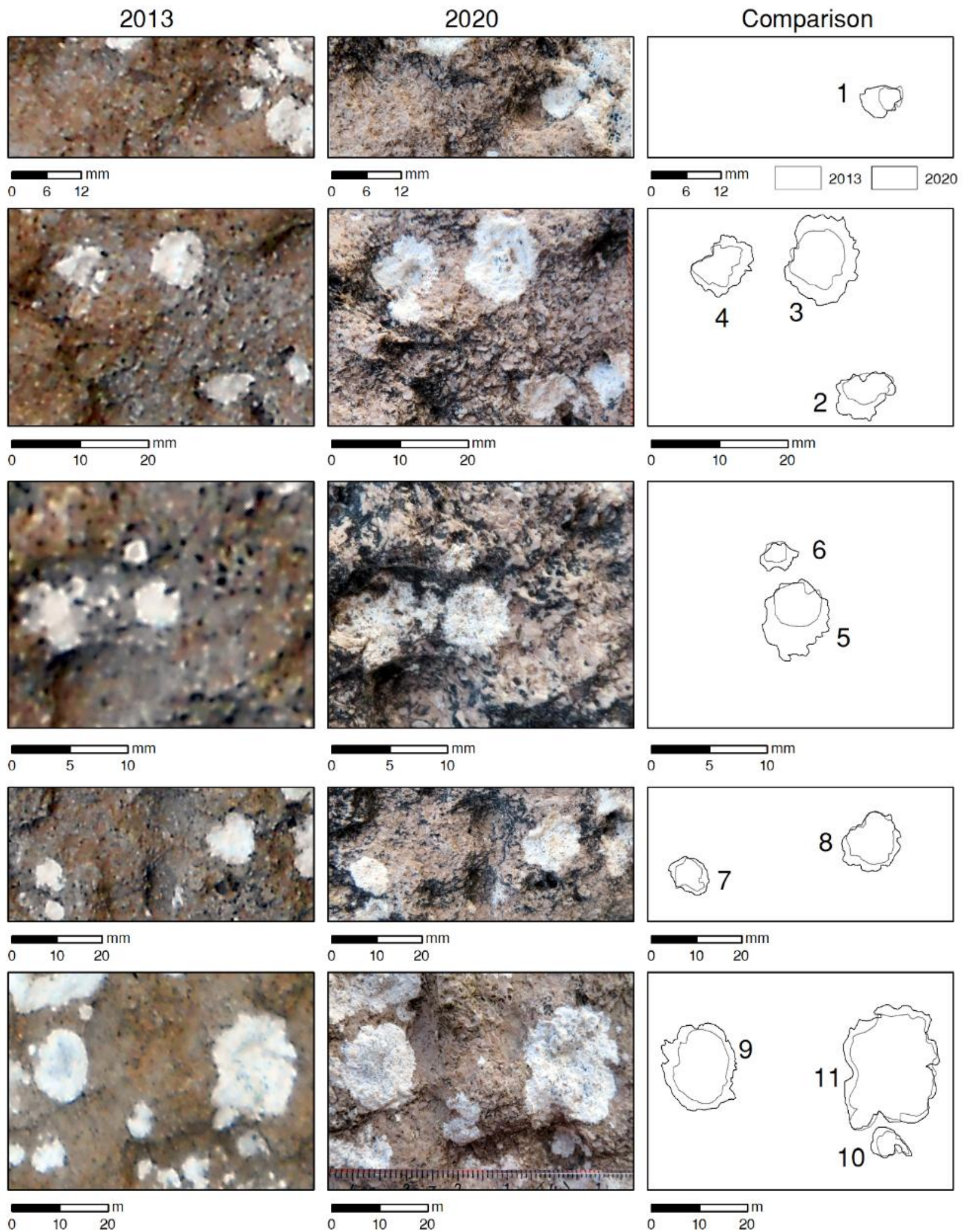

Figure S24: Photographs of lichens used for direct measurement of growth in 2013 and 2020 in RF02 control surface and comparison between the outline of lichen thalli. 

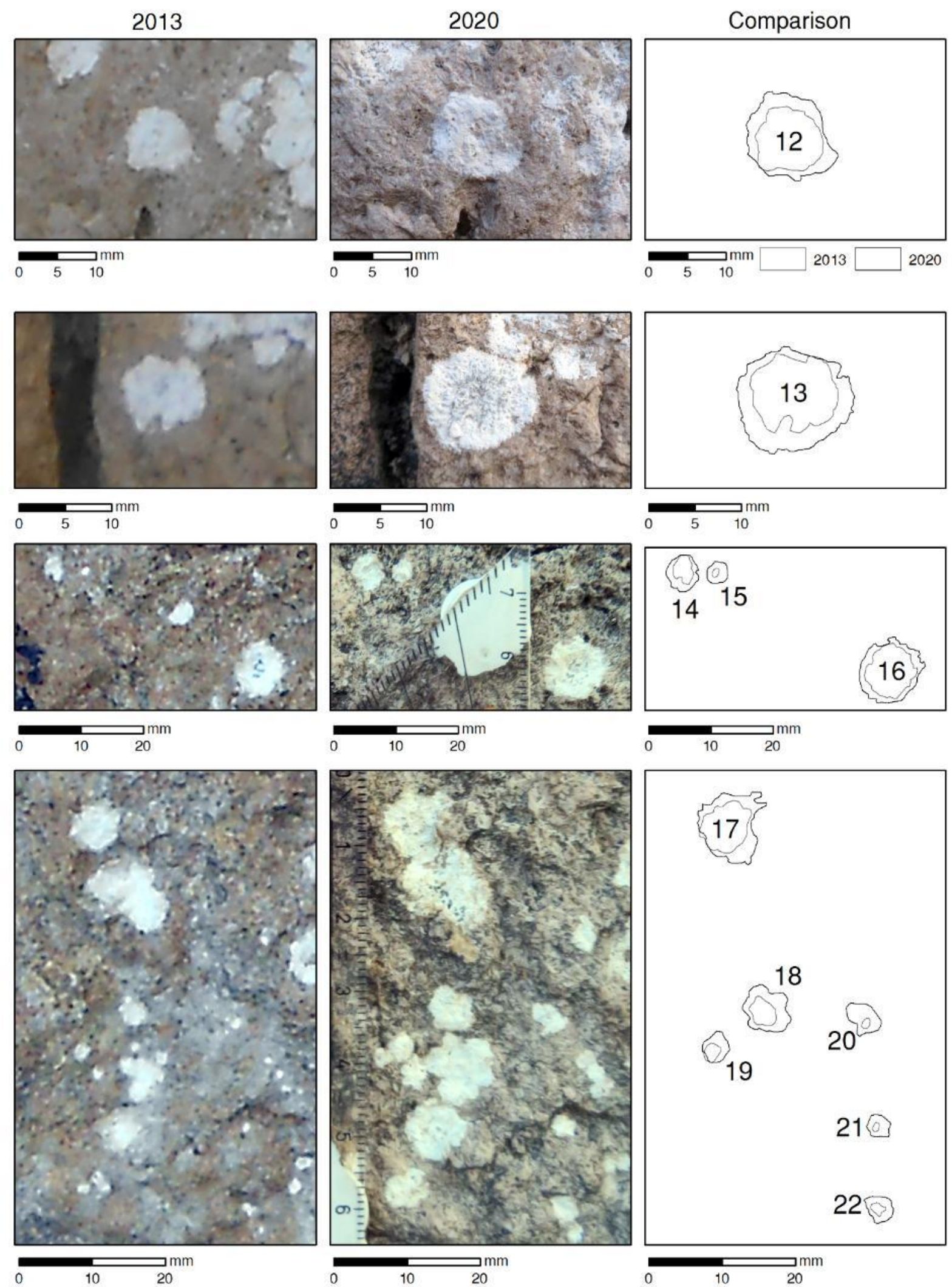

Figure S25: Photographs of lichens used for direct measurement of growth in 2013 and 2020 in RF02 control surface and comparison between the outline of lichen thalli. 

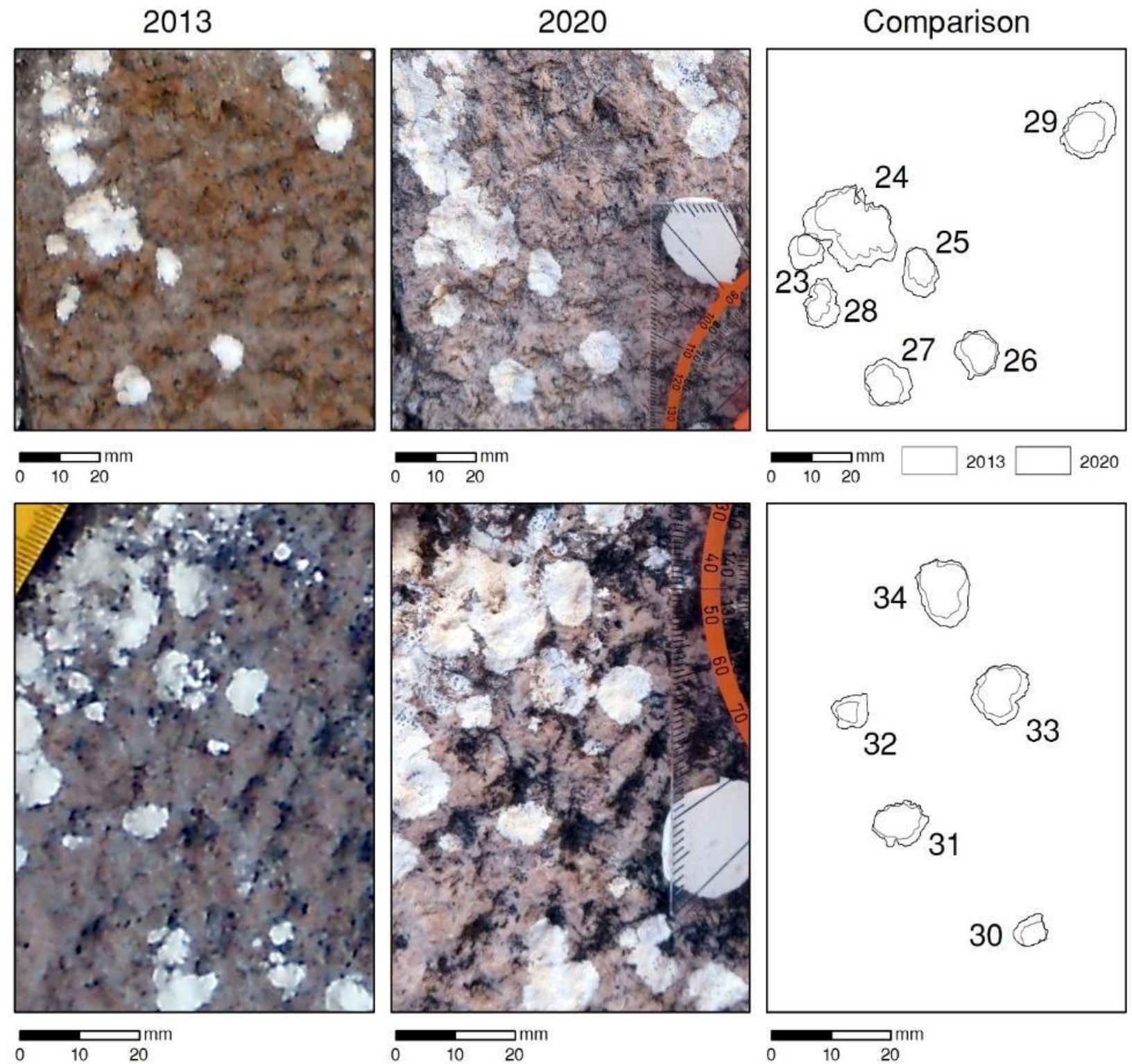

Figure S26: Photographs of lichens used for direct measurement of growth in 2013 and 2020 in RF02 control surface and comparison between the outline of lichen thalli. 

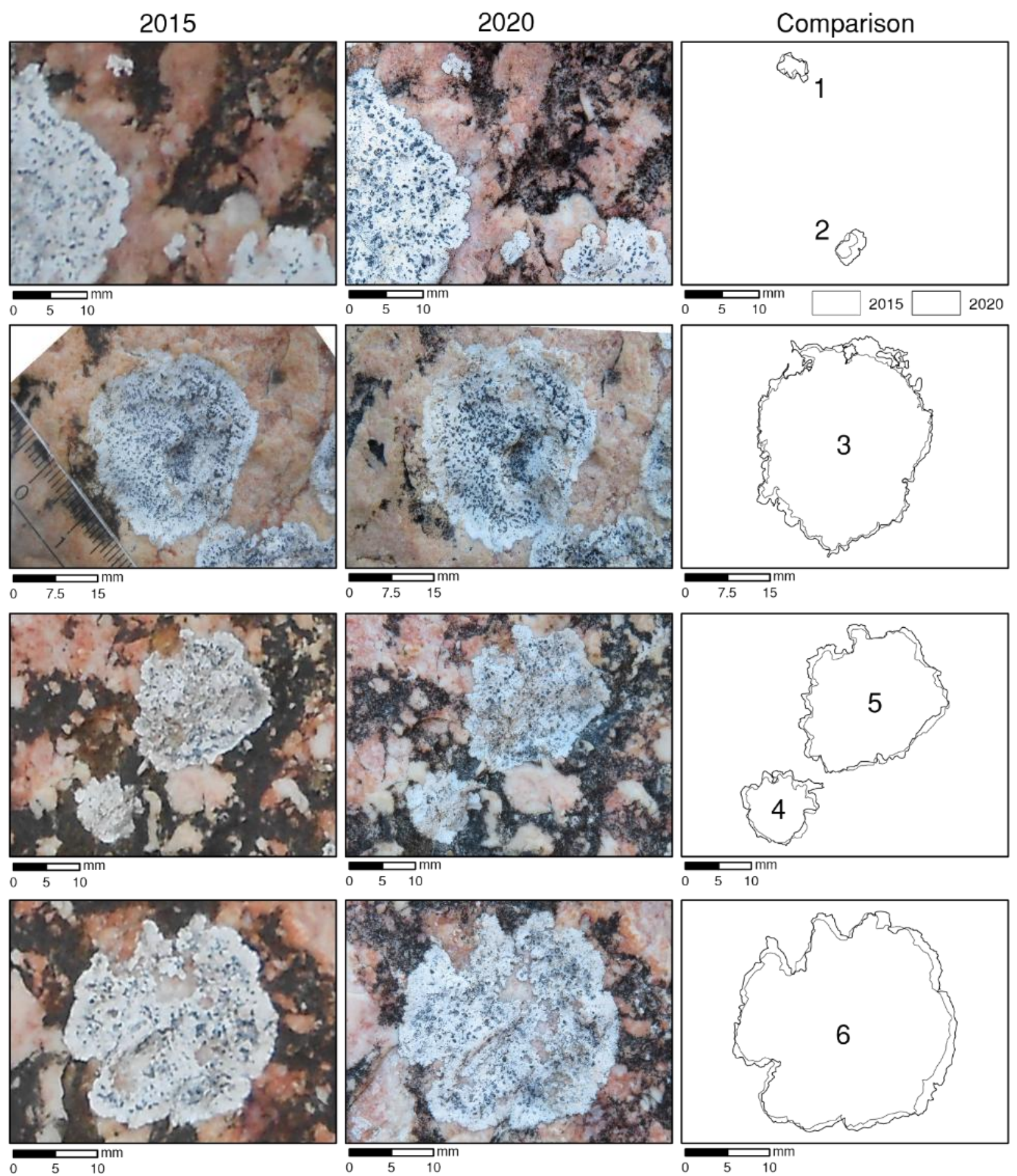

Figure S27: Photographs of lichens used for direct measurement of growth in 2015 and 2020 in AF03 control surface and comparison between the outline of lichen thalli. 

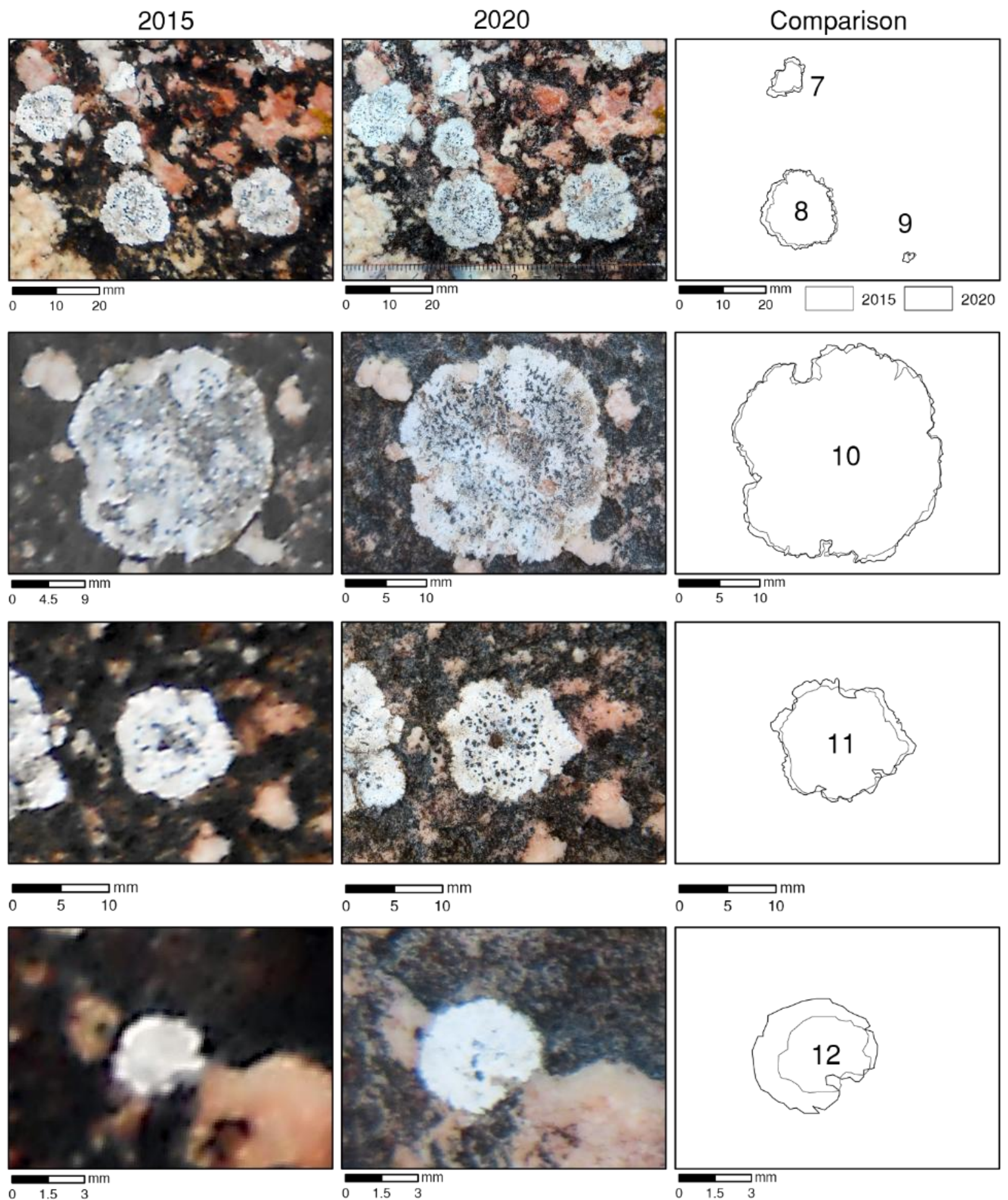

Figure S28: Photographs of lichens used for direct measurement of growth in 2015 and 2020 in AF03 control surface and comparison between the outline of lichen thalli. 


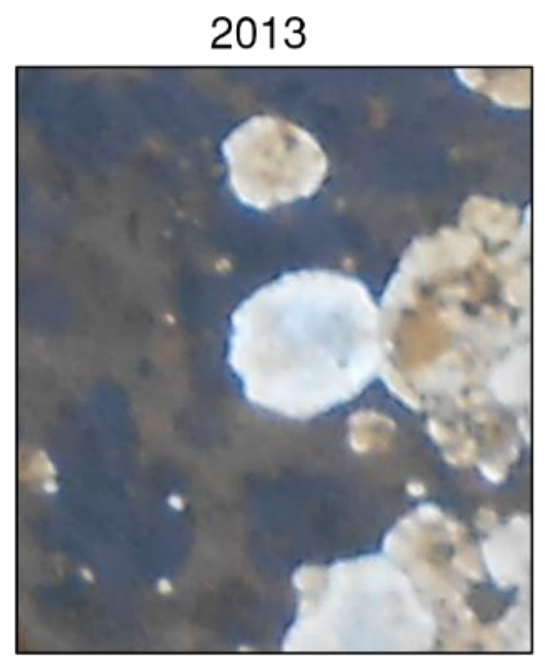

ㄴ 5 mm

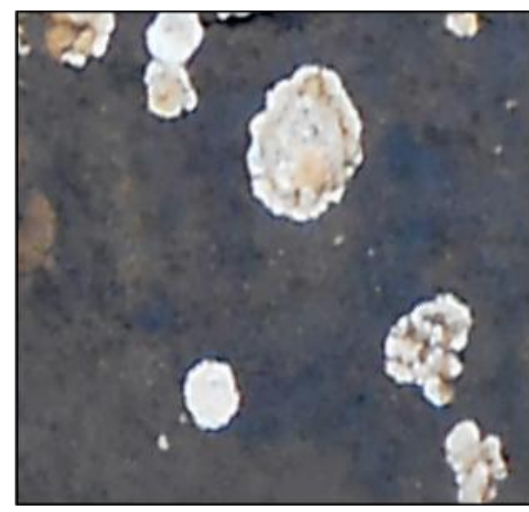

$\begin{array}{lll} & & \\ 0 & 10 & 20\end{array}$
2020

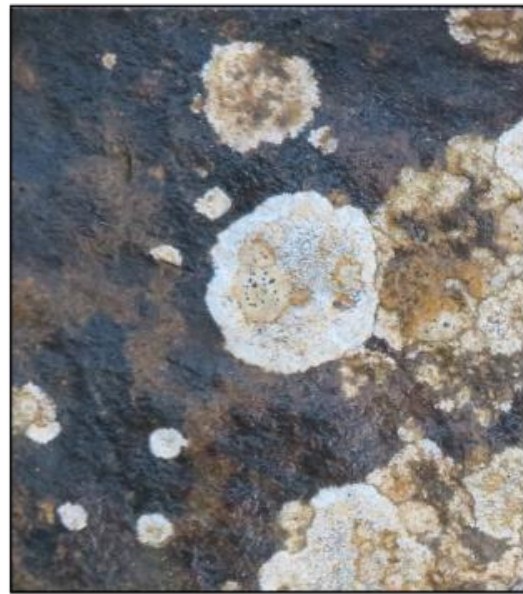

点
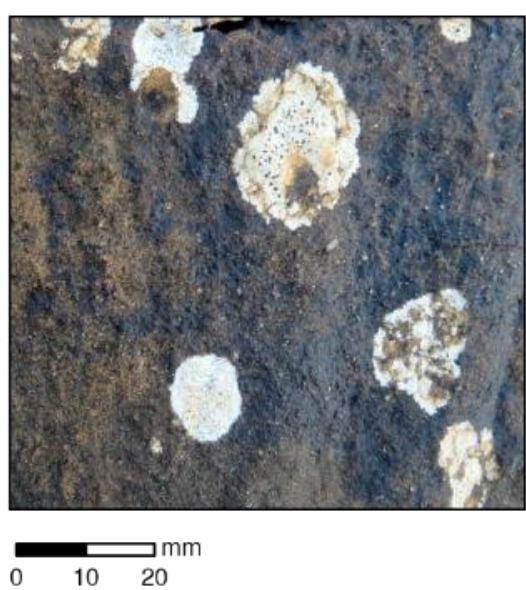

Comparison
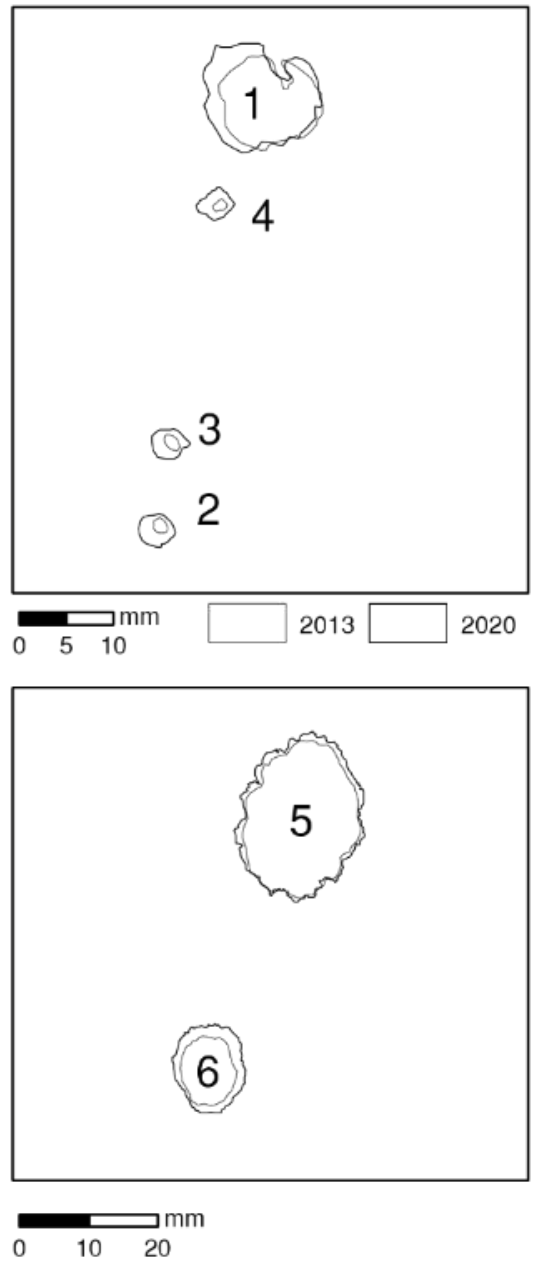

Figure S29: Photographs of lichens used for direct measurement of growth in 2013 and 2020 in RF06 control surface and comparison between the outline of lichen thalli. 


\section{AF05 Baluarte Redondo: 1558}
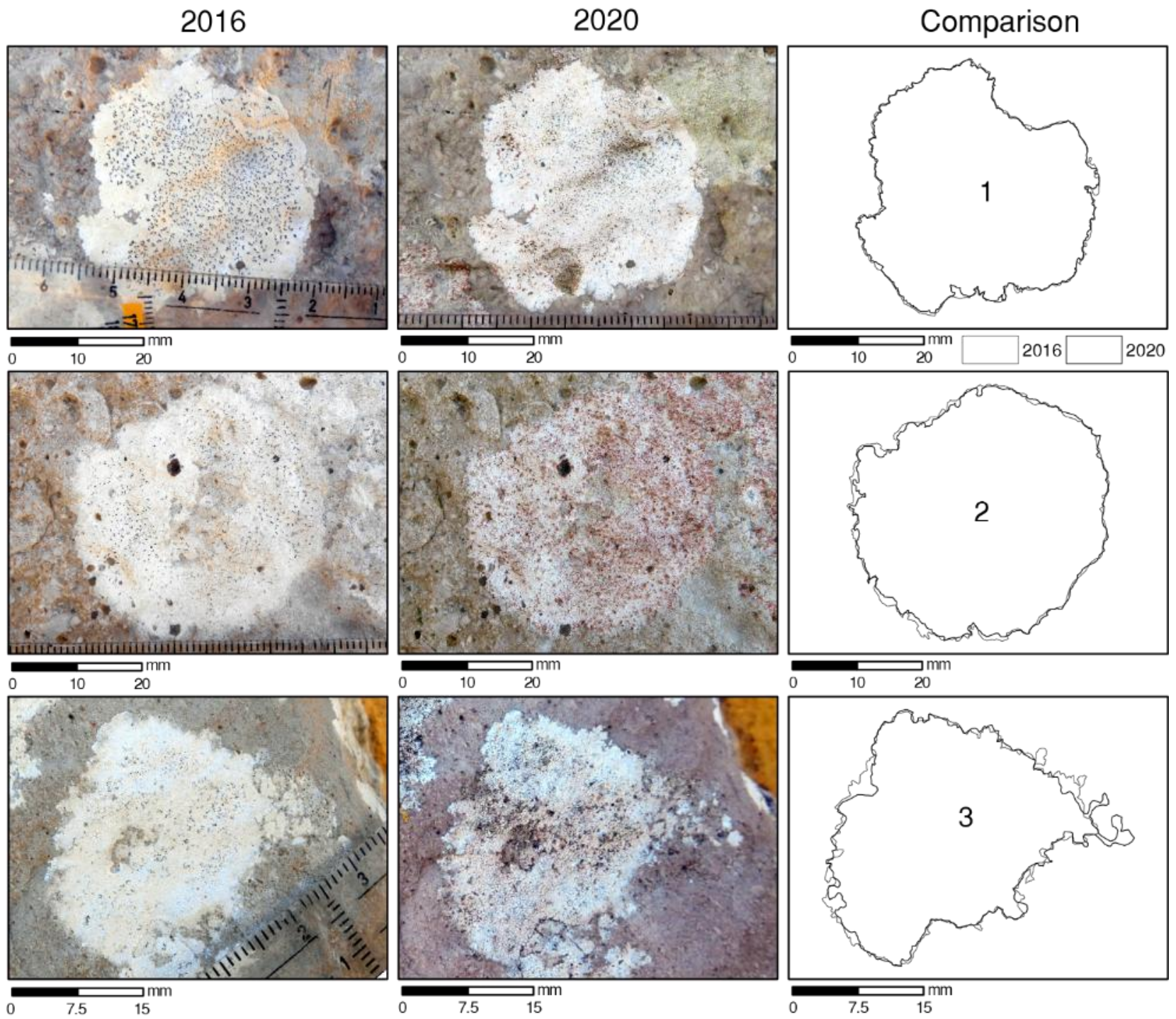

Figure S30: Photographs of lichens used for direct measurement of growth in 2016 and 2020 in AF05 Baluarte Redondo control point and comparison between the outline of lichen thalli. 


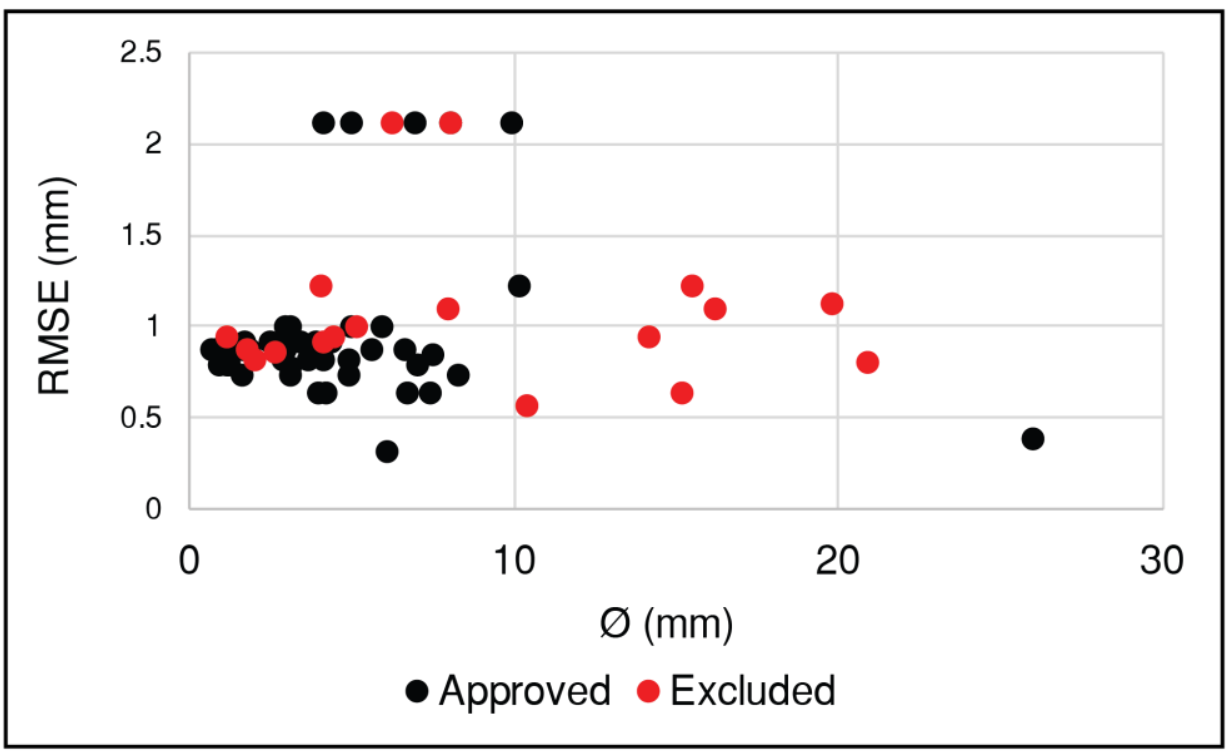

Figure S31: Scatter plot of the georeferencing RMSE against the largest inscribed circle of the thalli. Data excluded due to RMSE > changes in $\varnothing$ are represented in red, and the remaining dataset is represented in black.

\section{Age estimation of boulder stabilization}

Table S4: Boulder mass, lichen age parameters, and estimated ages obtained with the $\varnothing$ and $A$ growth models. BCE-Before Common Era; CE-Common Era. Shaded cells overlap the 1755 tsunami. * boulders with two overlapping lichen populations.

\begin{tabular}{|c|c|c|c|c|c|c|c|c|}
\hline \multirow{2}{*}{$\begin{array}{c}\text { Boulder } \\
\text { ID }\end{array}$} & \multirow{2}{*}{$\begin{array}{c}\text { Mass } \\
(\mathrm{t})\end{array}$} & $\begin{array}{c}\varnothing \\
(\mathrm{mm})\end{array}$ & $\begin{array}{c}A \\
\left(\mathrm{~mm}^{2}\right)\end{array}$ & $\begin{array}{c}\text { Sampling } \\
\text { year }\end{array}$ & $\begin{array}{c}\text { Estimated } \\
\text { age }\end{array}$ & $\begin{array}{c}\text { Prediction } \\
\text { interval }\end{array}$ & $\begin{array}{c}\text { Estimated } \\
\text { age }\end{array}$ & $\begin{array}{c}\text { Prediction } \\
\text { interval }\end{array}$ \\
\hline B1614 & 2.24 & 48.2 & 1825 & 2015 & $25 \mathrm{BCE}$ & $\begin{array}{c}3165 \mathrm{BCE}- \\
1211 \mathrm{CE}\end{array}$ & $1348 \mathrm{CE}$ & $\begin{array}{c}1201- \\
1494 \mathrm{CE}\end{array}$ \\
\hline B1540 & 1.91 & 46.4 & 1691 & 2015 & $406 \mathrm{E}$ & $\begin{array}{c}2017 \mathrm{BCE}- \\
1373 \mathrm{CE}\end{array}$ & $1398 \mathrm{CE}$ & $\begin{array}{c}1257- \\
1538 \mathrm{CE}\end{array}$ \\
\hline B1536 & 5.26 & 39.2 & 1207 & 2015 & $1394 \mathrm{CE}$ & $521-1756 \mathrm{CE}$ & $1580 \mathrm{CE}$ & $\begin{array}{c}1456- \\
1704 \mathrm{CE}\end{array}$ \\
\hline B1543 & 0.64 & 36.4 & 1041 & 2016 & $1587 \mathrm{CE}$ & $996-1835 \mathrm{CE}$ & $1644 \mathrm{CE}$ & $\begin{array}{c}1523- \\
1765 \mathrm{CE}\end{array}$ \\
\hline B1556 & 20.56 & 31.6 & 784 & 2015 & $1787 \mathrm{CE}$ & $\begin{array}{c}1481- \\
1918 \mathrm{CE}\end{array}$ & $1739 \mathrm{CE}$ & $\begin{array}{c}1621- \\
1857 \mathrm{CE}\end{array}$ \\
\hline B1542 & 10.47 & 27.0 & 573 & 2015 & $1891 \mathrm{CE}$ & $\begin{array}{c}1726- \\
1961 \mathrm{CE}\end{array}$ & $1819 \mathrm{CE}$ & $\begin{array}{c}1701- \\
1936 \mathrm{CE}\end{array}$ \\
\hline B1306 & 0.50 & 25.6 & 515 & 2016 & $1913 \mathrm{CE}$ & $\begin{array}{c}1776- \\
1971 \mathrm{CE}\end{array}$ & $1842 \mathrm{CE}$ & $\begin{array}{c}1724- \\
1959 \mathrm{CE}\end{array}$ \\
\hline B1544 & 13.89 & 25.0 & 491 & 2015 & $1919 \mathrm{CE}$ & $\begin{array}{c}1793- \\
1974 \mathrm{CE}\end{array}$ & $1850 \mathrm{CE}$ & $\begin{array}{c}1732- \\
1967 \mathrm{CE}\end{array}$ \\
\hline B1473 & 0.66 & 23.4 & 430 & 2012 & $1935 \mathrm{CE}$ & $\begin{array}{c}1832- \\
1979 \mathrm{CE}\end{array}$ & $1869 \mathrm{CE}$ & $\begin{array}{c}1751-1988 \\
\mathrm{CE}\end{array}$ \\
\hline
\end{tabular}




\begin{tabular}{|c|c|c|c|c|c|c|c|c|}
\hline \multirow[b]{2}{*}{$\begin{array}{l}\text { Boulder } \\
\text { ID }\end{array}$} & \multirow[b]{2}{*}{$\begin{array}{l}\text { Mass } \\
(\mathrm{t})\end{array}$} & \multirow[b]{2}{*}{$\begin{array}{c}\varnothing \\
(\mathrm{mm})\end{array}$} & \multirow[b]{2}{*}{$\begin{array}{c}A \\
\left(\mathrm{~mm}^{2}\right)\end{array}$} & \multirow{2}{*}{$\begin{array}{c}\text { Sampling } \\
\text { year }\end{array}$} & \multicolumn{2}{|c|}{$\varnothing$-based model } & \multicolumn{2}{|c|}{$A$-based model } \\
\hline & & & & & $\begin{array}{c}\text { Estimated } \\
\text { age }\end{array}$ & $\begin{array}{c}\text { Prediction } \\
\text { interval }\end{array}$ & $\begin{array}{c}\text { Estimated } \\
\text { age }\end{array}$ & $\begin{array}{c}\text { Prediction } \\
\text { interval }\end{array}$ \\
\hline B1492 & 0.26 & 20.6 & 333 & 2012 & $1958 \mathrm{CE}$ & $\begin{array}{c}1887- \\
1989 \mathrm{CE}\end{array}$ & 1906CE & $\begin{array}{c}1786- \\
2025 \mathrm{CE}\end{array}$ \\
\hline B1362 & 0.09 & 19.2 & 290 & 2012 & $1967 \mathrm{CE}$ & $\begin{array}{c}1908- \\
1993 \mathrm{CE}\end{array}$ & 1922CE & $\begin{array}{c}1802- \\
2043 \mathrm{CE}\end{array}$ \\
\hline B1517 & 0.24 & 18.2 & 260 & 2012 & $1973 \mathrm{CE}$ & $\begin{array}{c}1920- \\
1995 \mathrm{CE}\end{array}$ & 1933CE & $\begin{array}{c}1813- \\
2054 \mathrm{CE}\end{array}$ \\
\hline B1333* & 0.10 & 18.6 & 272 & 2016 & $1975 \mathrm{CE}$ & $\begin{array}{c}1920- \\
1998 C E\end{array}$ & 1933CE & $\begin{array}{c}1813- \\
2054 \mathrm{CE}\end{array}$ \\
\hline B1532 & 0.28 & 18.2 & 260 & 2016 & 1977CE & $\begin{array}{c}1924- \\
1999 \mathrm{CE}\end{array}$ & 1937CE & $\begin{array}{c}1817- \\
2058 \mathrm{CE}\end{array}$ \\
\hline B1509* & 4.85 & 17.2 & 232 & 2012 & 1978CE & $\begin{array}{c}1931- \\
1997 \mathrm{CE}\end{array}$ & 1944CE & $\begin{array}{c}1823- \\
2065 \mathrm{CE}\end{array}$ \\
\hline B1496 & 0.26 & 17.0 & 227 & 2012 & 1978CE & $\begin{array}{c}1933- \\
1998 \mathrm{CE}\end{array}$ & 1946CE & $\begin{array}{c}1825- \\
2067 \mathrm{CE}\end{array}$ \\
\hline B1493 & 3.52 & 16.8 & 222 & 2012 & 1979CE & $\begin{array}{c}1935- \\
1998 C E\end{array}$ & 1948CE & $\begin{array}{c}1826- \\
2069 \mathrm{CE}\end{array}$ \\
\hline B1367 & 1.79 & 16.2 & 206 & 2012 & $1982 \mathrm{CE}$ & $\begin{array}{c}1941- \\
1999 \mathrm{CE}\end{array}$ & 1954CE & $\begin{array}{c}1832- \\
2075 \mathrm{CE}\end{array}$ \\
\hline B1504* & 1.03 & 16.2 & 206 & 2012 & $1982 \mathrm{CE}$ & $\begin{array}{c}1941- \\
1999 \mathrm{CE}\end{array}$ & 1954CE & $\begin{array}{c}1832- \\
2075 \mathrm{CE}\end{array}$ \\
\hline B1140 & 1.74 & 14.8 & 172 & 2012 & 1987CE & $\begin{array}{c}1953- \\
2001 \mathrm{CE}\end{array}$ & 1967CE & $\begin{array}{c}1844- \\
2089 \mathrm{CE}\end{array}$ \\
\hline B1481 & 5.88 & 13.0 & 133 & 2012 & 1992CE & $\begin{array}{c}1965- \\
2003 \mathrm{CE}\end{array}$ & 1981CE & $\begin{array}{c}1858- \\
2105 \mathrm{CE}\end{array}$ \\
\hline B1143 & 0.43 & 12.6 & 125 & 2012 & $1993 \mathrm{CE}$ & $\begin{array}{c}1967- \\
2004 \mathrm{CE}\end{array}$ & 1984CE & $\begin{array}{c}1861- \\
2108 \mathrm{CE}\end{array}$ \\
\hline B1280 & 1.06 & 13.0 & 133 & 2016 & 1996CE & $\begin{array}{c}1969- \\
2007 \mathrm{CE}\end{array}$ & 1985CE & $\begin{array}{c}1862- \\
2109 \mathrm{CE}\end{array}$ \\
\hline B1512 & 0.71 & 12.4 & 121 & 2012 & $1994 \mathrm{CE}$ & $\begin{array}{c}1968- \\
2004 \mathrm{CE}\end{array}$ & 1986CE & $\begin{array}{c}1862- \\
2109 \mathrm{CE}\end{array}$ \\
\hline B1451 & 2.80 & 12.2 & 117 & 2012 & 1994CE & $\begin{array}{c}1969- \\
2004 \mathrm{CE}\end{array}$ & $1987 \mathrm{CE}$ & $\begin{array}{c}1864- \\
2111 \mathrm{CE}\end{array}$ \\
\hline B1406 & 0.56 & 8.8 & 61 & 2012 & 2000CE & $\begin{array}{c}1984- \\
2007 \mathrm{CE}\end{array}$ & 2008CE & $\begin{array}{c}1883- \\
2133 \mathrm{CE}\end{array}$ \\
\hline B1452 & 2.00 & 8.8 & 61 & 2012 & 2000CE & $\begin{array}{c}1984- \\
2007 \mathrm{CE}\end{array}$ & 2008CE & $\begin{array}{c}1883- \\
2133 \mathrm{CE}\end{array}$ \\
\hline B1502 & 3.17 & 7.6 & 45 & 2012 & 2002CE & $\begin{array}{c}1988- \\
2008 \mathrm{CE}\end{array}$ & $2014 \mathrm{CE}$ & $\begin{array}{c}1889- \\
2140 \mathrm{CE}\end{array}$ \\
\hline B1515 & 0.15 & 6.2 & 30 & 2012 & 2004CE & $\begin{array}{c}1992- \\
2008 \mathrm{CE}\end{array}$ & 2020CE & $\begin{array}{c}1894- \\
2146 \mathrm{CE}\end{array}$ \\
\hline B1144 & 1.15 & 5.8 & 26 & 2012 & 2004CE & $\begin{array}{c}1993- \\
2008 \mathrm{CE}\end{array}$ & $2021 \mathrm{CE}$ & $\begin{array}{c}1895- \\
2147 \mathrm{CE}\end{array}$ \\
\hline B1533 & 5.01 & 6.6 & 34 & 2015 & 2006CE & $\begin{array}{c}\text { 1994- } \\
2011 \mathrm{CE}\end{array}$ & $2021 \mathrm{CE}$ & $\begin{array}{c}1896- \\
2147 \mathrm{CE}\end{array}$ \\
\hline B1264 & 0.90 & 3.6 & 10 & 2012 & 2006CE & $\begin{array}{c}\text { 1997- } \\
\text { 2009CE }\end{array}$ & $2028 \mathrm{CE}$ & $\begin{array}{c}1901- \\
2154 \mathrm{CE}\end{array}$ \\
\hline
\end{tabular}

Page 38 of 41 


\section{Geometric relationship between $\emptyset$ and $A$}

The relationship between the radius and the area of a circle is quadratic and represented by the following equation:

$$
A=\pi r^{2}
$$

For a given increase in circle size, the increment in radius (and diameter) is smaller than the area increase. In Figure S32, the increase in radius (or diameter) between $t_{1}$ and $t_{2}$ (represented by the grey portion of the circle) and between $t_{2}$ and $t_{3}$ (represented by the hatched portion of the circle) is the same (diameter increase of $10 \mathrm{~mm}$ ). However, the increase in area is $30 \%$ higher for the larger circle (of $54978 \mathrm{~mm}^{2}$ from $\mathrm{t}_{1}$ to $\mathrm{t}_{2}$ and of $70686 \mathrm{~mm}^{2}$ from $\mathrm{t}_{2}$ and $\mathrm{t}_{3}$ ).
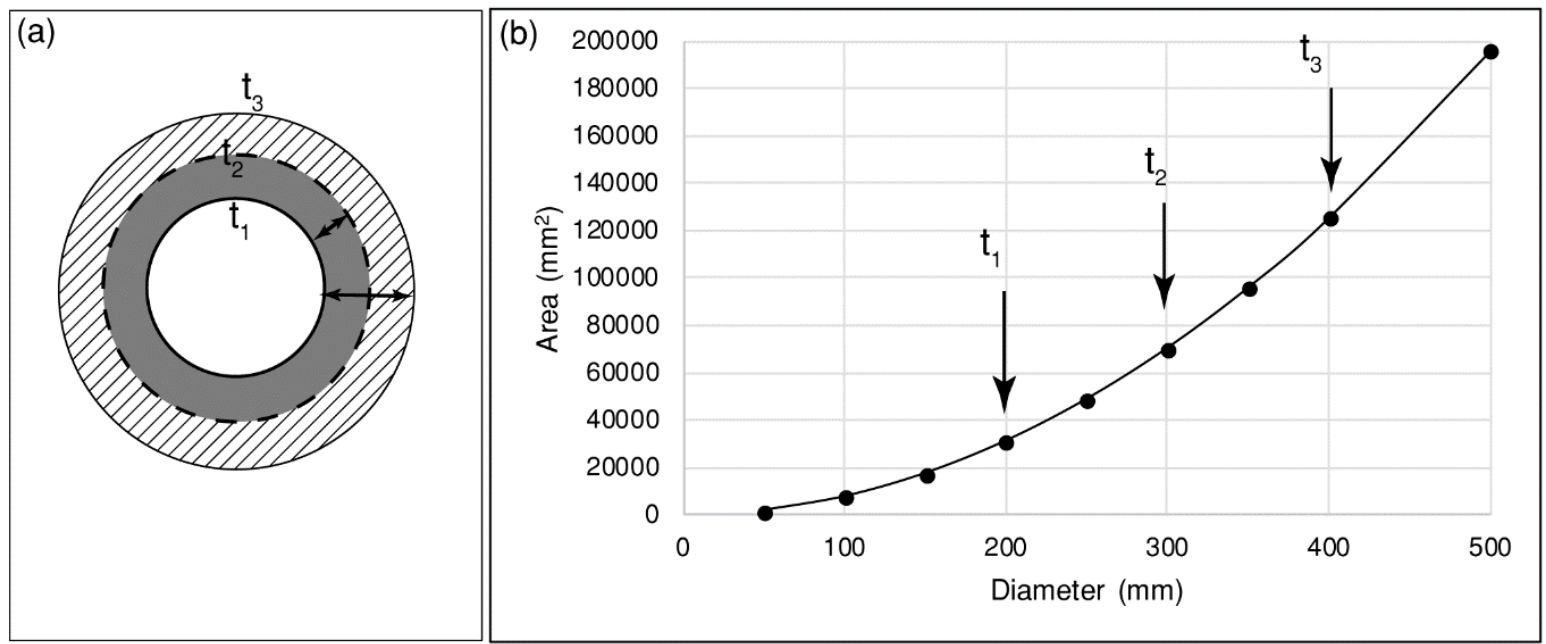

Figure S32: Representation of the relationship between the area and diameter of a circle. (a) $10 \mathrm{~mm}$ diameter increase between $\mathrm{t} 1$ and $\mathrm{t} 2$ and $\mathrm{t} 2$ and $\mathrm{t} 3$. (b) The increase in area is progressively higher with diameter increase.

\section{References}

Almeida J (1946) Roteiro dos monumentos militares portugueses, Vol II Distritos de Aveiro, Coimbra, Leiria e Santarém. Almeida J (in portuguese).

Costa AG (1997) Os fortes costeiros de Santa Susana e S. Pedro de Milreu, no concelho de Mafra. Boletim Cultural da Câmara de Mafra 96: 105-132 (in portuguese). 
Coutinho C (1997) Castelos Fortalezas e Torres da região do Algarve. Algarve em Foco

Editora (in portuguese).

Direção Geral dos Edifícios e Monumentos Nacionais (1953) Forte da Berlenga. Boletim da Direção Geral dos Edifícios e Monumentos Nacionais, 74 (in Portuguese).

Direção Geral dos Edifícios e Monumentos Nacionais (1960) Monumentos de Sagres. Boletim da Direção Geral dos Edifícios e Monumentos Nacionais, 100 (in portuguese).

Fick SE and Hijmans RJ (2017) Worldclim 2: New 1-km spatial resolution climate surfaces for global land areas. International Journal of Climatology, 37: 4302-4315.

IGEO (2010). Ortophotos. Available at WMS server http://mapas.igeo.pt/ortos/2010?

[Accessed on 1 May 2016].

Machado JLS (2009) O Forte de S. Miguel Arcanjo, Monumento Histórico-Militar do séc

XVII. Edições Colibri/Câmara Municipal da Nazaré (in portuguese).

Mateus MFRC (1999) Fortificações da região de Peniche. Msc Thesis, Universidade de Lisboa (in portuguese).

Mesquita JCV (2000) Sagres um lugar na história e no património universal. AJEA Edições (in portuguese).

Oliveira MA (2017) Boulder deposits related to extreme marine events in the western coast of Portugal. Ph.D thesis, Universidade de Lisboa, Portugal.

Quaresma AM (2007) Alexandre Massai, a “escola italiana” de engenharia militar no litoral Alentejano (séculos XVI e XVII). Centro Cultural Emmerico Nunes (in portuguese).

Severino CMM (2014) De Sagres a Tróia - Fortalezas 1580-1680. Msc Thesis, Universidade de Évora (in portuguese). 
Silva PFT (2013) O restauro da Fortaleza de Sagres no Estado Novo. VOX MUSEI arte e patrimônio, 2(3): 190-198 (in portuguese).

Page 41 of 41 


\begin{tabular}{|c|c|c|c|c|c|c|c|c|c|c|c|c|}
\hline & & & & & & & & al lichen Area & & Largest incribe & jed circle & \\
\hline Control Point & LichenREF & RMSE (mm) & Observations & $\begin{array}{l}\text { Initial date, ti (dd- } \\
\text { mm-yyyy) }\end{array}$ & $\begin{array}{c}\text { Final date, tf (dd- } \\
\text { mm-yyyy) }\end{array}$ & $\underset{\text { (years) }}{\text { Time period, } \Delta t}$ & $\mathbf{A i}\left(\mathrm{mm}^{2}\right)$ & Growth rate $\left(\mathrm{mm}^{2} / \mathrm{yr}\right)$ & $\mathbf{A i}\left(\mathrm{mm}^{2}\right)$ & $\begin{array}{l}\text { Growth rate } \\
\left(\mathrm{mm}^{2} / \text { year }\right)\end{array}$ & Øi (mm) & $\begin{array}{l}\begin{array}{l}\text { Growth rate } \\
(\mathrm{mm} / \text { year })\end{array} \\
\end{array}$ \\
\hline & 1 & 0.28 & & $9 / 25 / 2013$ & $1 / 19 / 2020$ & 6.32 & 0 & 0.24 & 0 & 0.14 & 0 & \\
\hline & 2 & 0.28 & & 9/25/2013 & $1 / 19 / 2020$ & 6.32 & 0 & 0.17 & 0 & 0.10 & 0 & \\
\hline & 3 & 0.23 & & $9 / 25 / 2013$ & $1 / 19 / 2020$ & 6.32 & 0 & 0.21 & 0 & 0.15 & 0 & \\
\hline & 4 & 0.23 & & 9/25/2013 & $1 / 19 / 2020$ & 6.32 & 0 & 0.12 & 0 & 0.11 & 0 & \\
\hline & 5 & 0.23 & & 9/25/2013 & $1 / 19 / 2020$ & 6.32 & 0 & 0.08 & 0 & 0.07 & 0 & \\
\hline & 6 & 0.23 & & 9/25/2013 & $1 / 19 / 2020$ & 6.32 & 0 & 0.23 & 0 & 0.16 & 0 & \\
\hline & 7 & 0.23 & & 9/25/2013 & $1 / 19 / 2020$ & 6.32 & 0 & 0.23 & 0 & 0.17 & 0 & \\
\hline RF01 S. & 8 & 0.23 & & $9 / 25 / 2013$ & $1 / 19 / 2020$ & 6.32 & 0 & 0.16 & 0 & 0.14 & 0 & \\
\hline Lourenço rock- & 9 & 0.16 & & 9/25/2013 & $1 / 19 / 2020$ & 6.32 & 0 & 0.17 & 0 & 0.13 & 0 & \\
\hline fall 2011/2012 & 10 & 0.11 & & 9/25/2013 & $1 / 19 / 2020$ & 6.32 & 0 & 0.19 & 0 & 0.16 & 0 & \\
\hline & 11 & 0.11 & & 9/25/2013 & $1 / 19 / 2020$ & 6.32 & 0 & 0.21 & 0 & 0.18 & 0 & \\
\hline & 12 & 0.11 & & $9 / 25 / 2013$ & $1 / 19 / 2020$ & 6.32 & 0 & 0.14 & 0 & 0.11 & 0 & \\
\hline & 13 & 0.11 & & 9/25/2013 & $1 / 19 / 2020$ & 6.32 & 0 & 0.12 & 0 & 0.10 & 0 & \\
\hline & 14 & 0.21 & & 9/25/2013 & $1 / 19 / 2020$ & 6.32 & 0 & 0.18 & 0 & 0.14 & 0 & \\
\hline & 15 & 0.13 & & $9 / 25 / 2013$ & $1 / 19 / 2020$ & 6.32 & 0 & 0.24 & 0 & 0.18 & 0 & \\
\hline & 16 & 0.13 & & 9/25/2013 & $1 / 19 / 2020$ & 6.32 & 0 & 0.12 & 0 & 0.10 & 0 & \\
\hline & 17 & 0.13 & & $9 / 25 / 2013$ & $1 / 19 / 2020$ & 6.32 & 0 & 0.14 & 0 & 0.12 & 0 & \\
\hline & 1 & 0.9 & & 9/25/2013 & $1 / 19 / 2020$ & 6.32 & 9.38 & 4.70 & 7.12 & 2.74 & 3.01 & \\
\hline & 2 & & 9 RMSE $>\Delta \emptyset$ & 9/25/2013 & 1/19/2020 & 6.32 & 16.62 & 3.15 & 13.82 & 0.51 & 4.19 & \\
\hline & 3 & 0.9 & & $9 / 25 / 2013$ & $1 / 19 / 2020$ & 6.32 & 3.47 & 2.40 & 2.45 & 1.72 & 1.77 & \\
\hline & 4 & 0.9 & & 9/25/2013 & $1 / 19 / 2020$ & 6.32 & 17.60 & 3.01 & 12.55 & 1.06 & 4.00 & \\
\hline & 5 & 0.9 & & 9/25/2013 & $1 / 19 / 2020$ & 6.32 & 16.04 & 3.37 & 9.77 & 1.18 & 3.53 & \\
\hline $\begin{array}{l}\text { RF02 S. } \\
\text { Lourenco rock- }\end{array}$ & 6 & 0.9 & & 9/25/2013 & 1/19/2020 & 6.32 & 27.50 & 5.58 & 15.57 & 1.56 & 4.45 & \\
\hline $\begin{array}{l}\text { Lourenço orock- } \\
\text { fall } 2005 / 2006\end{array}$ & 7 & 0.9 & & 9/25/2013 & $1 / 19 / 2020$ & 6.32 & 9.38 & 3.70 & 5.17 & 2.99 & 2.56 & \\
\hline Tail 2005/2000 & 8 & 0.8 & & 9/25/2013 & 1/19/2020 & 6.32 & 9.69 & 6.51 & 6.82 & 3.22 & 2.95 & \\
\hline & 9 & 0.8 & & 9/25/2013 & $1 / 19 / 2020$ & 6.32 & 28.58 & 7.25 & 19.71 & 3.99 & 5.01 & \\
\hline & 10 & 0.8 & & 9/25/2013 & $1 / 19 / 2020$ & 6.32 & 18.20 & 5.60 & 14.14 & 3.55 & 4.24 & \\
\hline & 11 & & 8 RMSE $>\Delta \emptyset$ & 9/25/2013 & $1 / 19 / 2020$ & 6.32 & 6.61 & 0.93 & 3.45 & 0.29 & 2.10 & \\
\hline & 12 & 0.8 & & 9/25/2013 & $1 / 19 / 2020$ & 6.32 & 14.48 & 5.34 & 11.06 & 1.86 & 3.75 & \\
\hline & 1 & 0.76 & & $12 / 26 / 2013$ & $1 / 20 / 2020$ & 6.07 & 12.96 & 2.40 & 7.98 & 1.68 & 3.19 & \\
\hline & 2 & 0.62 & & $12 / 26 / 2013$ & $1 / 20 / 2020$ & 6.07 & 23.56 & 2.90 & 14.73 & 1.09 & 4.33 & \\
\hline & 3 & 0.62 & & $12 / 26 / 2013$ & $1 / 20 / 2020$ & 6.07 & 51.72 & 8.26 & 36.81 & 4.53 & 6.85 & \\
\hline & 4 & 0.62 & & $12 / 26 / 2013$ & $1 / 20 / 2020$ & 6.07 & 27.17 & 3.67 & 12.86 & 1.70 & 4.05 & \\
\hline & 5 & 0.72 & & $12 / 26 / 2013$ & $1 / 20 / 2020$ & 6.07 & 12.17 & 2.60 & 8.15 & 2.02 & 3.22 & \\
\hline & 6 & 0.72 & & $12 / 26 / 2013$ & $1 / 20 / 2020$ & 6.07 & 2.89 & 0.37 & 2.25 & 0.10 & 1.69 & \\
\hline & 7 & 0.72 & & $12 / 26 / 2013$ & $1 / 20 / 2020$ & 6.07 & 32.08 & 3.40 & 19.87 & 2.81 & 5.03 & \\
\hline & 8 & 0.72 & & $12 / 26 / 2013$ & $1 / 20 / 2020$ & 6.07 & 88.01 & 5.40 & 55.15 & 3.88 & 8.38 & \\
\hline & 9 & 1.2 & & $12 / 26 / 2013$ & $1 / 20 / 2020$ & 6.07 & 134.80 & 13.52 & 82.58 & 10.80 & 10.25 & \\
\hline & 10 & & $2 \operatorname{RMSE}>\Delta \emptyset$ & $12 / 26 / 2013$ & $1 / 20 / 2020$ & 6.07 & 23.17 & 1.51 & 13.48 & 0.75 & 4.14 & \\
\hline & 11 & & 2 RMSE $>\Delta \emptyset$ & $12 / 26 / 2013$ & $1 / 20 / 2020$ & 6.07 & 329.86 & 11.25 & 190.42 & 3.17 & 15.57 & \\
\hline & 12 & 0.82 & & $12 / 26 / 2013$ & $1 / 20 / 2020$ & 6.07 & 57.85 & 6.29 & 45.54 & 4.50 & 7.61 & \\
\hline & 13 & 0.3 & & $12 / 26 / 2013$ & $1 / 20 / 2020$ & 6.07 & 60.26 & 7.76 & 30.31 & 9.26 & 6.21 & \\
\hline & 14 & 0.86 & & $12 / 26 / 2013$ & $1 / 20 / 2020$ & 6.07 & 10.82 & 1.95 & 6.29 & 1.70 & 2.83 & \\
\hline & 15 & 0.86 & & $12 / 26 / 2013$ & $1 / 20 / 2020$ & 6.07 & 1.17 & 1.36 & 0.74 & 1.14 & 0.97 & \\
\hline & 16 & 0.86 & & $12 / 26 / 2013$ & $1 / 20 / 2020$ & 6.07 & 50.47 & 4.39 & 35.57 & 4.46 & 6.73 & \\
\hline $\begin{array}{l}\text { AF0 Sta } \\
\text { Susana Forte }\end{array}$ & 17 & 0.86 & & $12 / 26 / 2013$ & $1 / 20 / 2020$ & 6.07 & 35.27 & 4.19 & 25.97 & 1.47 & 5.75 & \\
\hline $\begin{array}{c}\text { Susana Forte } \\
\text { 1944-1949 }\end{array}$ & 18 & 0.86 & & $12 / 26 / 2013$ & $1 / 20 / 2020$ & 6.07 & 10.30 & 3.31 & 7.34 & 2.04 & 3.06 & \\
\hline & 19 & 0.86 & & $12 / 26 / 2013$ & $1 / 20 / 2020$ & 6.07 & 4.26 & 1.10 & 3.02 & 0.85 & 1.96 & \\
\hline & 20 & 0.86 & & $12 / 26 / 2013$ & $1 / 20 / 2020$ & 6.07 & 1.18 & 2.15 & 0.72 & 1.06 & 0.96 & \\
\hline & 21 & 0.86 & & $12 / 26 / 2013$ & $1 / 20 / 2020$ & 6.07 & 0.84 & 1.11 & 0.51 & 0.91 & 0.80 & \\
\hline & 22 & 0.86 & & $12 / 26 / 2013$ & $1 / 20 / 2020$ & 6.07 & 2.24 & 1.34 & 1.29 & 1.02 & 1.28 & \\
\hline & 23 & 2.09 & & $12 / 26 / 2013$ & $1 / 20 / 2020$ & 6.07 & 26.25 & 5.44 & 20.65 & 3.91 & 5.13 & \\
\hline & 24 & 2.09 & & $12 / 26 / 2013$ & $1 / 20 / 2020$ & 6.07 & 212.12 & 17.43 & 78.71 & 14.18 & 10.01 & \\
\hline & 25 & & 9 RMSE $>\Delta \emptyset$ & $12 / 26 / 2013$ & $1 / 20 / 2020$ & 6.07 & 49.33 & 5.19 & 31.29 & 3.48 & 6.31 & \\
\hline & 26 & 2.09 & & $12 / 26 / 2013$ & $1 / 20 / 2020$ & 6.07 & 60.56 & 4.94 & 38.83 & 5.17 & 7.03 & \\
\hline & 27 & 2.09 & 9 RMSE $>\Delta \emptyset$ & $12 / 26 / 2013$ & $1 / 20 / 2020$ & 6.07 & 72.61 & 4.91 & 52.66 & 2.96 & 8.19 & \\
\hline & 28 & 2.09 & & $12 / 26 / 2013$ & $1 / 20 / 2020$ & 6.07 & 35.47 & 6.99 & 13.83 & 5.00 & 4.20 & \\
\hline & 29 & 2.09 & & $12 / 26 / 2013$ & $1 / 20 / 2020$ & 6.07 & 76.84 & 10.76 & 51.77 & 6.89 & 8.12 & \\
\hline & 30 & 0.98 & & $12 / 26 / 2013$ & $1 / 20 / 2020$ & 6.07 & 12.55 & 1.45 & 8.05 & 1.13 & 3.20 & \\
\hline & 31 & 0.98 & 8 RMSE $>\Delta \emptyset$ & $12 / 26 / 2013$ & $1 / 20 / 2020$ & 6.07 & 34.29 & 2.53 & 21.89 & 1.43 & 5.28 & \\
\hline & 32 & 0.98 & & $12 / 26 / 2013$ & $1 / 20 / 2020$ & 6.07 & 9.98 & 2.85 & 7.15 & 2.08 & 3.02 & \\
\hline & 33 & 0.98 & & $12 / 26 / 2013$ & $1 / 20 / 2020$ & 6.07 & 41.88 & 4.11 & 20.46 & 2.98 & 5.10 & \\
\hline & 34 & 0.98 & & $12 / 26 / 2013$ & $1 / 20 / 2020$ & 6.07 & 53.11 & 4.01 & 28.42 & 4.12 & 6.02 & \\
\hline & 1 & 0.85 & RMSE $>\Delta \emptyset$ & $11 / 13 / 2015$ & $1 / 25 / 2020$ & 4.20 & 7.79 & 0.38 & 2.82 & 0.12 & 1.90 & \\
\hline & 2 & 0.85 & & $11 / 13 / 2015$ & $1 / 25 / 2020$ & 4.20 & 5.79 & 1.38 & 2.33 & 0.76 & 1.72 & \\
\hline & 3 & 0.36 & 6 loosing areola in the middle of the thall & $11 / 13 / 2015$ & $1 / 25 / 2020$ & 4.20 & 765.25 & 20.90 & 535.95 & 3.64 & 26.12 & \\
\hline & 4 & 1.08 & RMSE $>\Delta \emptyset$ & $11 / 13 / 2015$ & $1 / 25 / 2020$ & 4.20 & 73.39 & 3.10 & 51.32 & -0.39 & 8.08 & \\
\hline & 5 & 1.08 & $\varnothing \operatorname{RMSE}>\Delta \emptyset$ & $11 / 13 / 2015$ & $1 / 25 / 2020$ & 4.20 & 318.50 & 5.25 & 208.89 & -3.49 & 16.31 & \\
\hline AF03 S Miguel & 6 & 1.1 & $1 \mathrm{RMSE}>\Delta \emptyset$ & $11 / 13 / 2015$ & $1 / 25 / 2020$ & 4.20 & 463.89 & 10.89 & 311.95 & 2.89 & 19.93 & \\
\hline Arcanjo 1645 & 7 & 0.92 & $2 \operatorname{RMSE}>\Delta \emptyset$ & $11 / 13 / 2015$ & $1 / 25 / 2020$ & 4.20 & 32.94 & 3.81 & 16.13 & 1.41 & 4.53 & \\
\hline & 8 & 0.92 & $2 \operatorname{RMSE}>\Delta \emptyset$ & $11 / 13 / 2015$ & $1 / 25 / 2020$ & 4.20 & 211.11 & 5.24 & 159.61 & 4.15 & 14.26 & \\
\hline & 9 & 0.92 & $2 \operatorname{RMSE}>\Delta \emptyset$ & $11 / 13 / 2015$ & $1 / 25 / 2020$ & 4.20 & 1.93 & 0.51 & 1.22 & 0.16 & 1.25 & \\
\hline & 10 & 0.79 & $9 \operatorname{RMSE}>\Delta \emptyset$ & $11 / 13 / 2015$ & $1 / 25 / 2020$ & 4.20 & 508.71 & 5.90 & 345.75 & -2.12 & 20.98 & \\
\hline & 11 & 0.55 & 5 RMSE $>\Delta \emptyset$ & $11 / 13 / 2015$ & $1 / 25 / 2020$ & 4.20 & 110.04 & 3.75 & 87.00 & -3.64 & 10.52 & \\
\hline & 12 & 0.84 & 4 RMSE $>\Delta \emptyset$ & $11 / 13 / 2015$ & $1 / 25 / 2020$ & 4.20 & 8.88 & 1.98 & 5.81 & 0.65 & 2.72 & \\
\hline & 1 & 0.77 & & $12 / 26 / 2013$ & $1 / 26 / 2020$ & 6.09 & 77.81 & 4.47 & 39.64 & 2.80 & 7.10 & \\
\hline AF06 Sta & 2 & 0.77 & & $12 / 26 / 2013$ & $1 / 26 / 2020$ & 6.09 & 1.86 & 1.36 & 1.44 & 1.11 & 1.35 & \\
\hline Susana fencing & 3 & 0.77 & & $12 / 26 / 2013$ & $1 / 26 / 2020$ & 6.09 & 1.98 & 1.25 & 1.20 & 1.04 & 1.24 & \\
\hline wall $1657-$ & 4 & 0.77 & & $12 / 26 / 2013$ & $1 / 26 / 2020$ & 6.09 & 1.31 & 1.19 & 0.87 & 0.84 & 1.05 & \\
\hline 1777 & 5 & 0.61 & 1 RMSE $>\Delta \emptyset$ & 12/26/2013 & $1 / 26 / 2020$ & 6.09 & 281.66 & 5.89 & 183.68 & 2.31 & 15.29 & \\
\hline & 6 & 0.61 & & $12 / 26 / 2013$ & $1 / 26 / 2020$ & 6.09 & 62.43 & 6.50 & 44.25 & 5.12 & 7.51 & \\
\hline AF05 Baularte & 1 & 0.249 & 9 loosing areola in the middle of the thall & $8 / 5 / 2016$ & $1 / 26 / 2020$ & 3.48 & 968.73 & -6.98 & 571.85 & -5.46 & 26.98 & \\
\hline Redondo 1558 & 2 & 0.2 & 2 loosing areola in the middle of the thall & $8 / 5 / 2016$ & $1 / 26 / 2020$ & 3.48 & 1177.86 & -9.15 & 880.71 & -10.01 & 33.49 & \\
\hline & 3 & 0.69 & 9 loosing areola in the middle of the thall & $8 / 5 / 2016$ & $1 / 26 / 2020$ & 3.48 & 549.91 & -4.59 & 352.37 & -16.97 & 21.18 & \\
\hline
\end{tabular}

Records in red were removed from the dataset 


\begin{tabular}{|c|c|c|c|c|c|c|c|c|c|c|c|c|c|c|}
\hline UNL \# & Field \# & $\begin{array}{c}\text { Burial } \\
\text { Depth (m) }\end{array}$ & $\begin{array}{l}\mathrm{H}_{2} \mathrm{O} \\
(\%)^{\mathrm{a}}\end{array}$ & $\begin{array}{l}\mathrm{K}_{2} \mathrm{O} \\
(\%)\end{array}$ & \pm & $\begin{array}{c}U \\
(\mathrm{ppm})\end{array}$ & \pm & $\begin{array}{c}\text { Th } \\
\text { (ppm) }\end{array}$ & \pm & $\begin{array}{c}\text { Cosmic } \\
\text { (Gy) }\end{array}$ & $\begin{array}{c}\text { Dose Rate } \\
\text { (Gy/ka) }\end{array}$ & $\begin{array}{l}D_{e} \\
(G y)\end{array}$ & $\begin{array}{c}\text { No. of } \\
\text { Aliquots }\end{array}$ & $\begin{array}{l}\text { Age } \\
\text { (ka) }\end{array}$ \\
\hline UNL4003 & Q20 CxS & 0.35 & 7.5 & 1.57 & 0.05 & 1.99 & 0.12 & 12.55 & 0.47 & 0.20 & $2.66 \pm 0.10$ & $3.86 \pm 0.36$ & 75 & $1.45 \pm 0.14$ \\
\hline UNL4004 & Q21 CxS & 0.35 & 9.6 & 1.90 & 0.05 & 1.83 & 0.10 & $\begin{array}{c}\text { Minimum Age } \\
9.62 \\
\text { Minimum }\end{array}$ & $\begin{array}{l}\text { Mode } \\
0.38\end{array}$ & $\begin{array}{l}\text { (Galbraith } \\
0.20 \\
\text { (Galhraith }\end{array}$ & $\begin{array}{r}\mathrm{t} \text { al., 1999) }= \\
2.63 \pm 0.10\end{array}$ & $\begin{array}{l}0.60 \pm 0.06 \\
3.95 \pm 0.47 \\
0.77+0.13\end{array}$ & 72 & $\begin{array}{l}0.23 \pm 0.02 \\
1.50 \pm 0.19 \\
0.29+0.05\end{array}$ \\
\hline
\end{tabular}

a In-situ Moisture Content

Error on De is 1 standard error

Error on age includes random and systematic errors calculated in quadrature 


\section{Dose Recovery Test on UNL4003:}

Preheat De

Temp ( $\left.{ }^{\circ} \mathrm{C}\right)$ (Gy) $\quad \pm$

$180 \quad 4.75 \quad 0.02$

$200 \quad 4.74 \quad 0.03$

$220 \quad 4.78 \quad 0.05$

$240 \quad 4.80 \quad 0.02$

$260 \quad 4.83 \quad 0.01$

$280 \quad 4.96 \quad 0.03$

Applied Dose $=\quad 4.77$

Recovered Dose $=\quad 4.81 \pm$

Gy

$0.08 \mathrm{~Gy}$

\section{Thermal Transfer Test on UNL4003:}

Preheat De

Temp $\left({ }^{\circ} \mathrm{C}\right)(\mathrm{Gy}) \quad \pm$

$\begin{array}{lll}180 & 0.01 & 0.01\end{array}$

$\begin{array}{lll}200 & -0.01 & 0.00\end{array}$

$\begin{array}{lll}220 & 0.01 & 0.01\end{array}$

$\begin{array}{lll}240 & 0.02 & 0.01\end{array}$

$\begin{array}{lll}260 & 0.03 & 0.01\end{array}$

$\begin{array}{lll}280 & 0.07 & 0.01\end{array}$

Thermal Transfer $=\quad 0.02 \pm$

0.02 Gy

\section{Preheat Plateau on UNL4003:}

Preheat De

Temp ( $\left.{ }^{\circ} \mathrm{C}\right)(\mathrm{Gy}) \quad \pm$

$\begin{array}{lll}180 & 4.35 & 0.75 \\ 200 & 4.21 & 0.73 \\ 220 & 4.07 & 0.52 \\ 240 & 3.76 & 0.46 \\ 260 & 6.22 & 2.19 \\ 280 & 4.56 & 0.80\end{array}$

Preheat of $240 \mathrm{C}$ used for analyses!
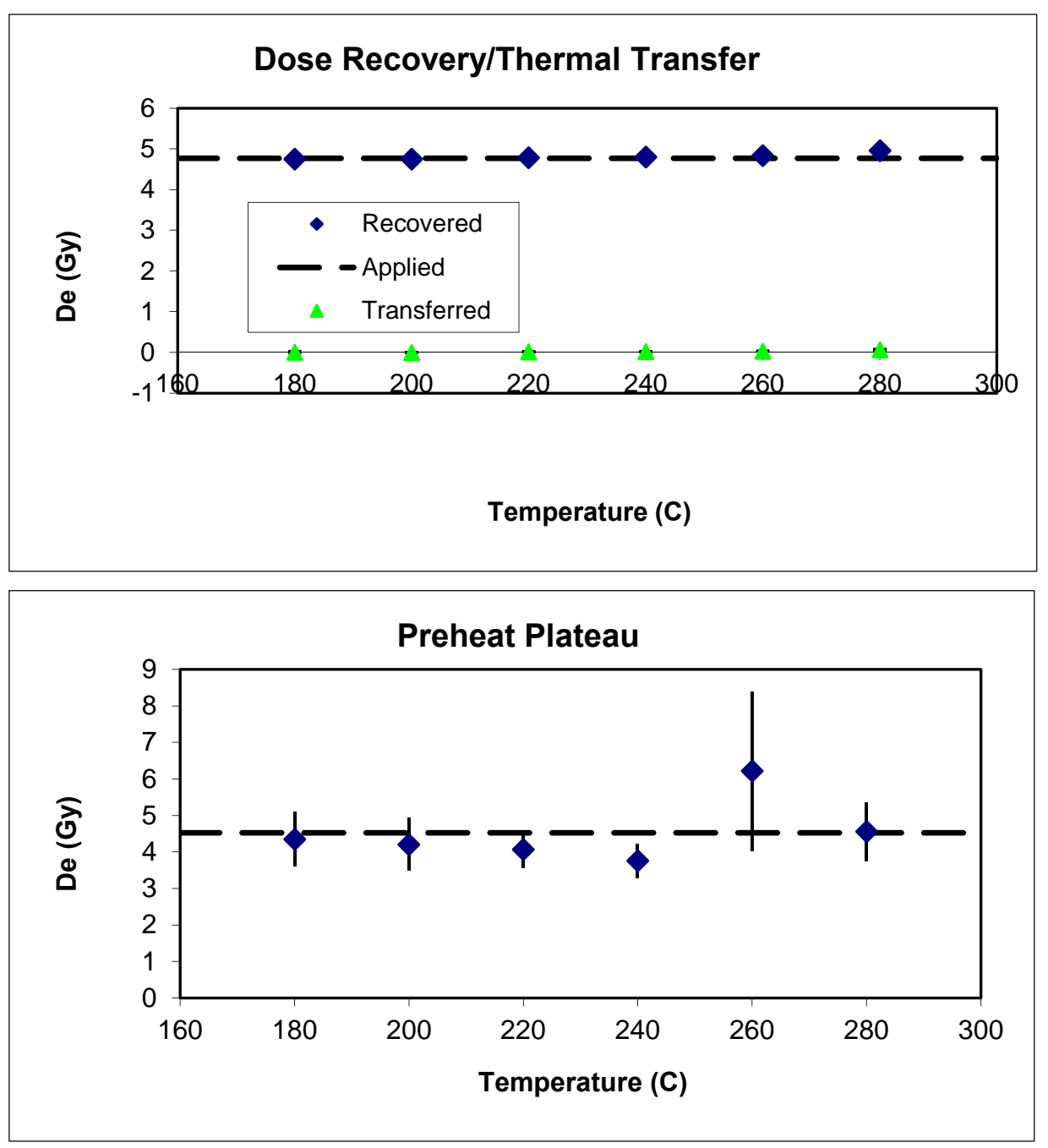


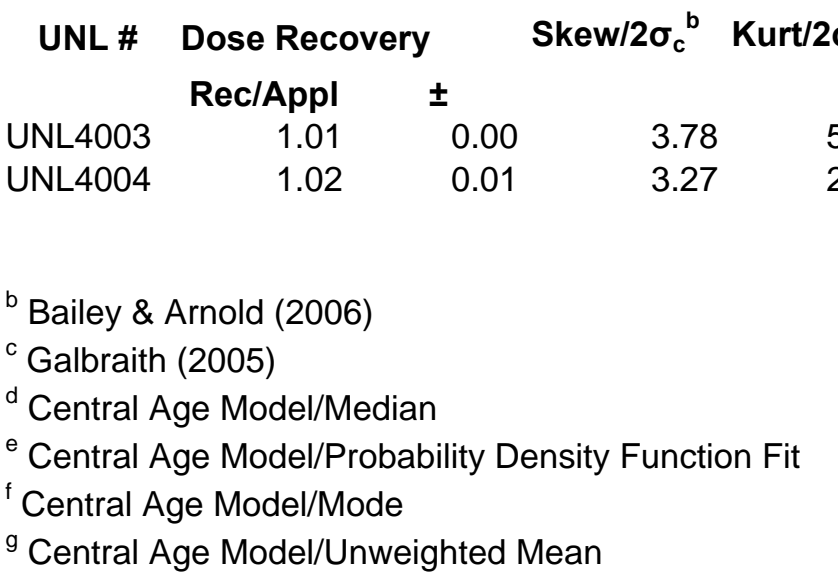

$c / c_{\text {crit }}{ }^{b} \quad k / k_{\text {crit }}{ }^{b}$ Overdisp (\%) ${ }^{c}$ CAM/Med ${ }^{d}$ CAM/PDF Fit ${ }^{e}$ CAM/Mode ${ }^{f}$ CAM/Mean

$\begin{array}{lllllll}0.31 & 3.13 & 80 & 1.04 & 1.10 & 1.05 & 0.71 \\ 0.28 & 1.56 & 99 & 1.14 & 1.68 & 2.95 & 0.59\end{array}$

\footnotetext{
${ }^{\mathrm{b}}$ Bailey \& Arnold (2006)

${ }^{\mathrm{c}}$ Galbraith (2005)

Central Age Model/Median

${ }^{f}$ Central Age Model/Mode

${ }^{9}$ Central Age Model/Unweighted Mean
} 